\title{
New Concepts in Cancer Biomarkers: Circulating miRNAs in Liquid Biopsies
}

\author{
Erika Larrea $^{1,+}$, Carla Sole ${ }^{1,+}$, Lorea Manterola ${ }^{1}$, Ibai Goicoechea ${ }^{1}$, María Armesto ${ }^{1}$, \\ María Arestin 1, María M. Caffarel 1,2, Angela M. Araujo 1, María Araiz ${ }^{3}$, \\ Marta Fernandez-Mercado ${ }^{1, \ddagger}$ and Charles H. Lawrie ${ }^{1,2,4, *, \ddagger}$ \\ 1 Molecular Oncology, Biodonostia Research Institute, 20014 San Sebastián, Spain; \\ erika.larrea@biodonostia.org (E.L.); carla.sole@biodonostia.org (C.S.); \\ lorea.manterola@biodonostia.org (L.M.); ibai.goicoechea@biodonostia.org (I.G.); \\ maria.armesto@biodonostia.org (M.Arm.); maria.arestin@biodonostia.org (M.Are.); \\ maria.caffarel@biodonostia.org (M.M.C.); angela.araujo@biodonostia.org (A.M.A.); \\ marta.fernandez@biodonostia.org (M.F.-M.) \\ 2 IKERBASQUE, Basque Foundation for Science, 48013 Bilbao, Spain \\ 3 Hematology Department, Donostia Hospital, 20014 San Sebastián, Spain; \\ maria.araizramirez@osakidetza.eus \\ 4 Nuffield Department of Clinical Laboratory Sciences, University of Oxford, Oxford OX3 9DU, UK \\ * Correspondence: charles.lawrie@biodonostia.org; Tel.: +34-943-006138; Fax: +34-943-006250 \\ + These authors contributed equally to this work. \\ $\ddagger$ Joint senior authors. \\ Academic Editor: William Chi-shing Cho \\ Received: 13 February 2016; Accepted: 18 April 2016; Published: 27 April 2016
}

\begin{abstract}
The effective and efficient management of cancer patients relies upon early diagnosis and/or the monitoring of treatment, something that is often difficult to achieve using standard tissue biopsy techniques. Biological fluids such as blood hold great possibilities as a source of non-invasive cancer biomarkers that can act as surrogate markers to biopsy-based sampling. The non-invasive nature of these "liquid biopsies" ultimately means that cancer detection may be earlier and that the ability to monitor disease progression and/or treatment response represents a paradigm shift in the treatment of cancer patients. Below, we review one of the most promising classes of circulating cancer biomarkers: microRNAs (miRNAs). In particular, we will consider their history, the controversy surrounding their origin and biology, and, most importantly, the hurdles that remain to be overcome if they are really to become part of future clinical practice.
\end{abstract}

Keywords: miRNAs; cfmiRNAs; liquid biopsies

\section{Introduction}

Cancer represents the leading cause of morbidity and mortality worldwide, with approximately 14 million new cases and 8.2 million cancer related deaths in 2012, and this number is predicted to rise by approximately $70 \%$ over the next two decades according to the World Health Organization [1]. The effective and efficient management of cancer patients relies upon both early diagnosis and the frequent monitoring of patient response to treatment.

The current gold standard of cancer diagnosis is the histological examination of tissue, obtained either by radiologically guided biopsy or surgical excision. However, these procedures are invasive, expensive, and not without risk to the patient. They also take time and need to be consistently evaluated by expert pathologists. Therefore, there is a clear clinical need for alternative diagnostic techniques. In particular, the use of biological fluids such as blood as a source of non-invasive biomarkers of cancer has raised a great deal of interest [2]. So-called "liquidbiopsies" hold great clinical 
promise, as their non-invasive nature allows for rapid, economical, and repeat sampling-features that permit their use in screening programs and for the close monitoring of treatment response and disease progression, allowing for earlier intervention and dynamic treatment management. Furthermore, there is an increasing awareness of the genetic heterogeneity of tumors and a realization that tissue biopsies may miss this diversity. Liquid biopsies in contrast can capture the entire genetic panorama of the tumoral landscape. Consequently, this technology has the potential to radically improve current treatment regimens and therefore the outcome of cancer patients, allowing for a personalized approach to be taken for each patient. Although the majority of liquid biopsy research to date has focused upon the isolation of circulating tumor cells (CTCs), these cells are relatively rare and require sensitive collection and enrichment technology. Increasingly, the focus of liquid biopsy studies is shifting towards circulating (or cell-free) nucleic acids (cfDNA/RNA) as being easier to collect and analyze. There has been a particular interest in circulating cell-free microRNAs (cfmiRNAs), the subject of this review. For a wider overview of circulating nucleic acids as cancer biomarkers-in particular, mRNA and non-coding RNAs other than microRNAs (miRNAs)—we refer the reader to our previous article [2].

The history of circulating (blood) nucleic acids goes back to a finding in 1947 by Mandel and Metais of RNA and DNA in the plasma of healthy and sick individuals [3]. Remarkably, this report predates the realization that DNA was the molecule responsible for inheritance and the discovery of the double helix structure by Watson and Crick. It was not until the 1960s when scientific interest was aroused by the finding of cfDNA in patients with the autoimmune diseases, systemic lupus erythematosus (SLE) [4] and rheumatoid arthritis [5]. However, it was not until 1977 when the potential of cfDNA as cancer biomarkers was postulated-when Leon et al. reported elevated levels of circulating cfDNA in pancreatic cancer patients [6]. After that, in 1994, cancer-specific DNA mutations in NRAS (myelodysplastic syndrome (MDS)) [7] and KRAS (pancreatic cancer) [8] were found in the blood of cancer patients. cfRNA, in contrast to cfDNA, was not identified until 1999, when Lo et al. first identified (viral) cfRNA in the blood of nasopharyngeal carcinoma patients [9]. Several years later, in 2007, our group reported the presence of miRNAs in the blood of lymphoma patients [10]; the following year, it was demonstrated that miRNAs could be useful as non-invasive biomarkers of cancer [11,12].

miRNAs are endogenous, small (18-24 nt), non-coding (nc) RNA molecules that regulate eukaryotic gene expression post-transcriptionally. miRNAs were unknown in science until just over 20 years ago, and, even then, were not formally recognized until 2001 [13]. There are now over 2500 human miRNAs that have been identified [14], and it is believed that nearly two thirds of all human genes are directly targeted by miRNAs [15]. miRNAs have been shown to play key regulatory roles in virtually every aspect of biology [16], including in the pathogenesis of cancer, and are aberrantly expressed in many diseases (Figure 1). Indeed, there is now compelling evidence that miRNAs regulate all aspects of the so-called "hallmarks of cancer" that enable tumor growth and metastatic dissemination [17,18] (Figure 2).

The field of circulating miRNAs has generated a great deal of interest and has been growing at an exponential rate with more than 2000 publications now published on the subject (source: PubMed; Figure 1), and many conferences and commercial entities are involved in this area. Below, we discuss some of the controversies behind the origin of these molecules and their possible functions. We also review some of the major evidence to suggest their potential as cancer biomarkers, but, most importantly, we discuss some the barriers that are still to be overcome if these molecules are to become a part of routine clinical practice. 


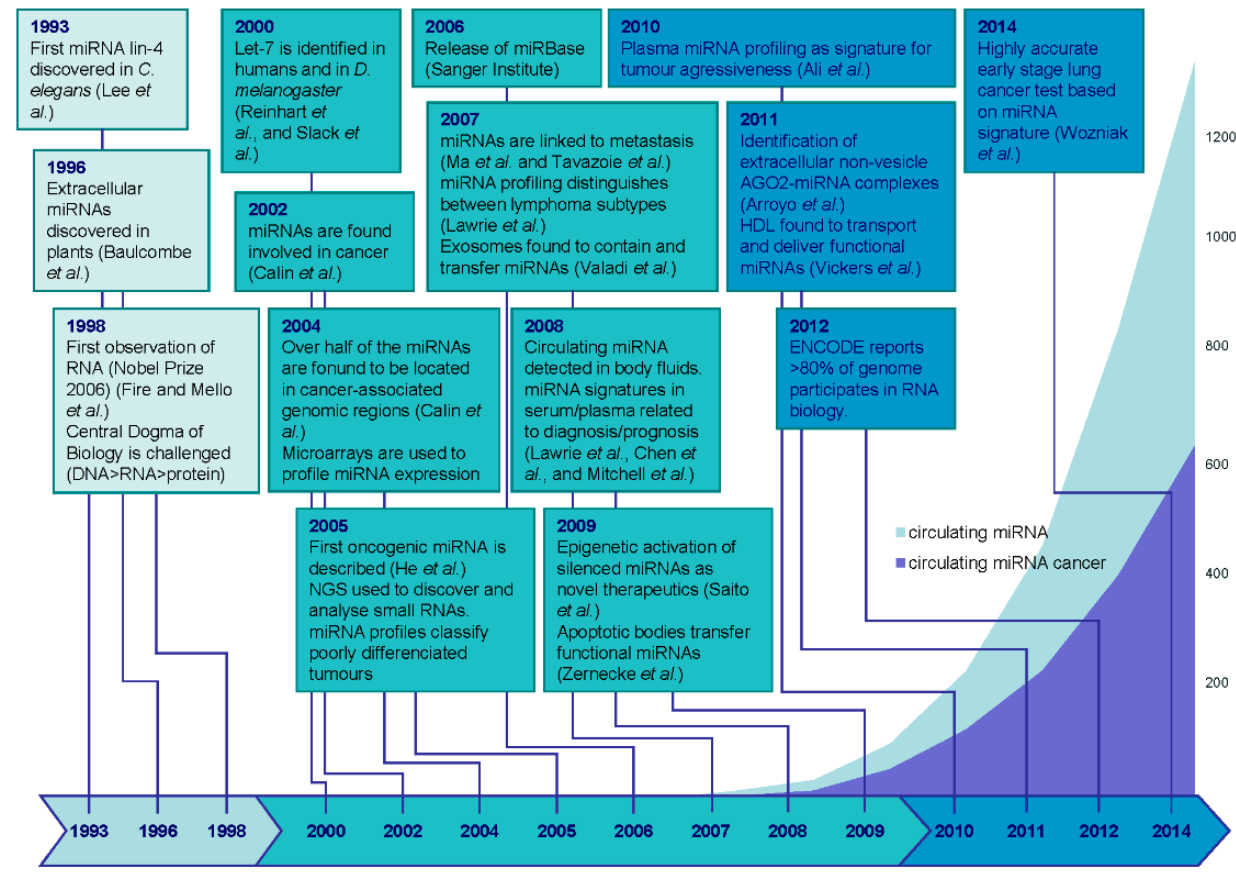

Figure 1. Chronological timeline of key discoveries in the microRNA (miRNA) field and their relevance to cancer. The overlapping plot depicts the number of PubMed-indexed publications for miRNA (dark blue) or miRNA related to cancer (light blue).

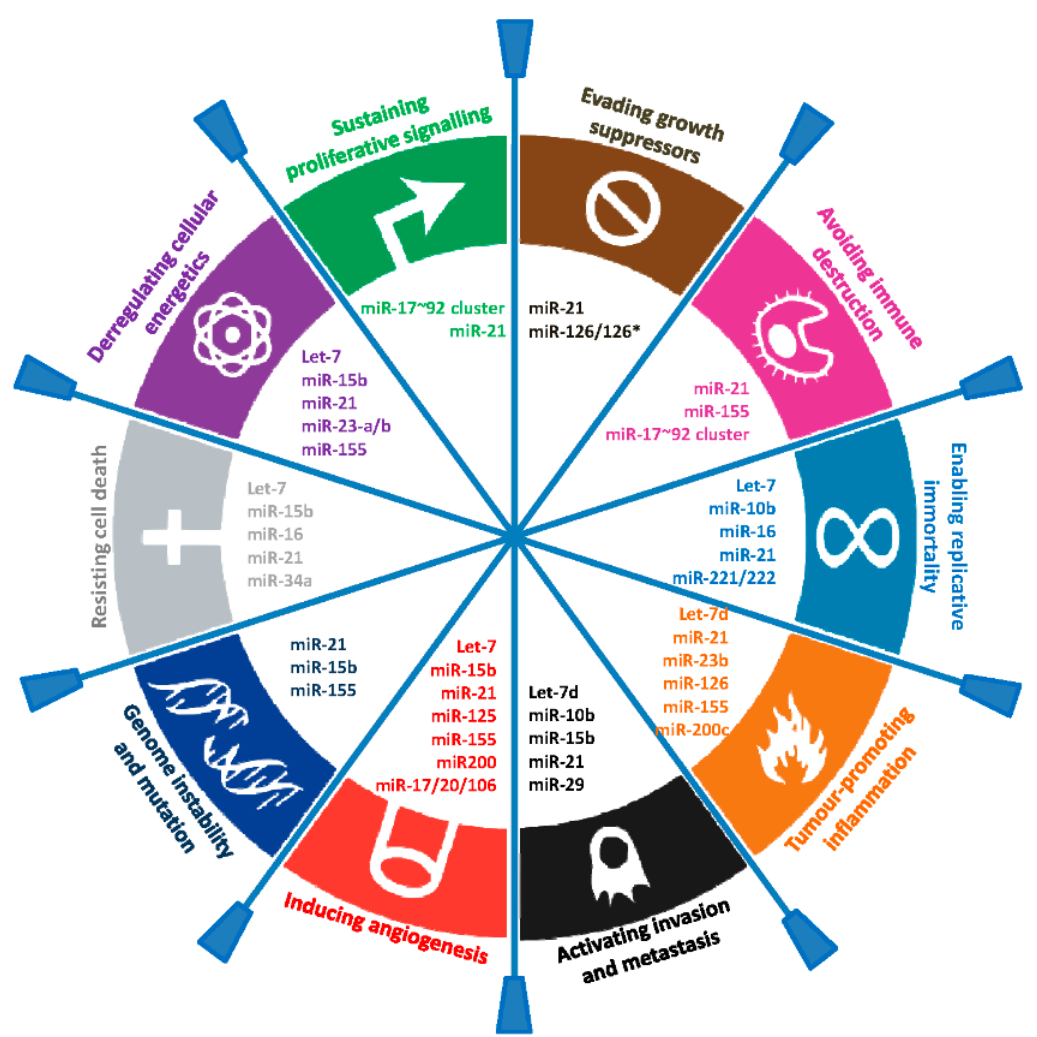

Figure 2. Selected circulating cell-free microRNAs (cfmiRNAs) and their functional role in the hallmarks of cancer.The figure lists some examples of biomarker cfmiRNAs (with a focus on the ones described in this review) that regulate genes involved in the different hallmarks of cancer as defined by Hanahan and Weinberg [18]. 


\subsection{Origin of Extracellular miRNAs}

There are several different hypotheses that have been proposed to explain the presence of circulating miRNAs in biological fluids [19-21]. These include the passive release of miRNAs from broken cells after tissue injury, cell apoptosis or necrosis, chronic inflammation, and from cells with a short half-life such as platelets [22-24]. For example, specific miRNAs are elevated in blood after myocardial infarction [24-26] or hepatobiliar injury [27]. An alternative hypothesis, though not mutually exclusive, is that miRNAs are actively secreted from cells either shuttled via microvesicles such as exosomes or shedding vesicles [12,28-30], or directly in complex with RNA-binding proteins or lipoproteins such as nucleophosmin (NPM1) [31], high-density lipoprotein (HDL) [32], or Argonaute proteins [22,33].

There is some controversy as to which of these represent the true origin of cfmiRNA, or at least the relative proportion of the different routes; until fairly recently, it was believed that most circulating miRNAs were derived from cell-derived vesicles [34].This has been contested by at least two independent reports that suggest that more than $90 \%$ of the miRNAs in blood are membrane-free and associated with Ago proteins [22,33]. Irrespective of their origin, the composition of cfmiRNAs appears to differ greatly from their respective donor cells [35]. In fact, some secreted miRNAs are notpresent at all in the parental cells [30].

\subsection{Cell-Cell Communication (Hormone-Like Molecules)}

Aside from their (passive) role as biomarkers, there has been a great deal of interest in the function of cfmiRNAs and in particular their ability to act as signaling molecules that potentially allow tumor cells to modify the bodies response to its own advantage. The first evidence that extracellular miRNAs could act as signaling molecules was discovered in plants in 1996 [36]. There is now emerging evidence of human miRNAs acting in a similar fashion either as paracrine signalers or even as systemic communicators between cells in an endocrine manner (in a hormone-like way) [20,37]. A number of facts support this possibility: miRNAs appear to be selectively packaged and secreted [31,38]; extracellular miRNAs are protected from RNases either by lipoprotein or protein carriers or by microvesicle membranes [33]; and circulating miRNAs are able to alter gene expression in recipient cells and mediate functional changes in them $[30,35,39,40]$. The first indication that miRNAs could shuttle between cells via exosomes was demonstrated in mast cells [29]. Later, the transfer of miRNAS between different cell types (embryonic stem cells and fibroblasts) was demonstrated [41]. More recently, exosomal miRNA has been shown to be able to modulate inmunological response through modification of the gene expression of antigen presenting cells (APC) by T-cells, B-cells, and dendritic cell-derived miRNAs [35].

Multiple studies suggest that cfmiRNAs could play a role in cancer biology through tumor-derived exosomal miRNA modulating non-tumor cells to the ultimate benefit of the tumor. For example, exosomal-cfmiRNAs have been demonstrated to modulate chemosensitivity [42], angiogenesis, and cell invasiveness [43-46]. While this is potentially a fascinating phenomena, this is still a contentious issue, and it is worth remembering that the few studies carried out to date have been almost exclusively in vitro. Finally, although Ago2-boundmiRNAs appear to form the majority of cfmiRNA, there is no evidence (or known mechanism) for the active release of vesicle-free AGO2-miRNA complexes in mammals, nor any indication of Ago-2 surface receptors for the uptake by recipient cells. Therefore, the physiological relevance of cfmiRNA as an intercellular signaling mechanism remains to be determined.

\section{2. miRNAs as Cancer Biomarkers}

According to the National Cancer Institute, a biomarker is defined as "a biological molecule found in blood, other body fluids, or tissues that are a sign of a normal or abnormal process, or of a condition or disease." In cancer, they can be divided into three general categories: (1) diagnostic biomarkers, which are used for a differential diagnosis; (2) prognostic biomarkers, which can distinguish tumors 
with a good outcome from those with a bad outcome; and (3) predictive biomarkers, which are for assessing whether a treatment is likely to be effective for a particular patient or not. An ideal biomarker should have a high specificity, sensitivity, and predictive power. miRNAs have a number of intrinsic characteristics that make them attractive as biomarkers. Firstly, they are highly specific, and it has been shown that miRNA expression profiles differ between cancer types according to diagnosis and the developmental stage of the tumor, with a greater resolution than traditional gene expression analysis [47]. Secondly, unlike other RNA classes, miRNAs are remarkably stable and therefore can be robustly measured not only in biological fluids but also from routinely prepared formalin-fixed paraffin-embedded (FFPE) material [48]. Indeed, unlike other RNA species, miRNAs appear resistant to boiling, $\mathrm{pH}$ changes, repeated freeze-thawing cycles, and fragmentation by chemical or enzymes $[12,20,49]$. It should be noted, however, that cfmiRNAs are not themselves intrinsically resilient to RNase or any other treatment; rather, they are protected by their lipidic or protein-based carrier $[12,50,51]$. As a result of these characteristics, the use of cfmiRNAs as biomarkers-and in particular as cancer biomarkers-has generated a plethora of publications over the last few years. Due to the limitations of space, we will not attempt to review all of these but instead discuss the more robust studies that identify common cfmiRNA biomarkers in multiple studies. More often than not, these biomarker miRNAs are themselves intimately involved in cancer pathology, as shown in Table 1, which includes their respective experimentally validated targets. While it may be tempting to speculate that these miRNAs may have the same effect while in circulation as intracellularly, there is no evidence that this is indeed the case.

Table 1. Examples of deregulated levels of circulating miRNAs in various malignancies proposed to have either diagnostic and/or prognostic value. MDS: Myelodysplastic syndrome; HCC: Hepatocellular carcinoma; MM: Multiple myeloma; DLBCL: Diffuse large B-cell lymphoma; HL: Hodgkin lymphoma; CNS: Central nervous system; AML: Acute myeloid leukemia; CLL: Chronic lymphocytic leukemia; ATL: Adult T-cell leukemia; BAL: Bronchoalveolar lavage; D: Diagnostic; PG: Prognostic; and PD: Predictive of response.

\begin{tabular}{|c|c|c|c|c|c|c|}
\hline \multirow{2}{*}{ Circulating miRNA } & \multirow{2}{*}{ Cancer Type } & \multirow{2}{*}{ Type of Biomarker } & \multirow{2}{*}{ Body Fluid Type } & \multicolumn{2}{|c|}{ Cohort Size } & \multirow{2}{*}{ Reference } \\
\hline & & & & Cases & Controls & \\
\hline \multirow{5}{*}{ let-7a } & Prostate & $\mathrm{D}$ & Blood & 75 & 27 & [52] \\
\hline & \multirow{2}{*}{ Colorectal } & $\mathrm{D}$ & Serum exosomes & 88 & 11 & [53] \\
\hline & & $\mathrm{D}$ & Plasma & 51 & 26 & [54] \\
\hline & MDS & PG & Plasma & 50 & 76 & [55] \\
\hline & Gastric & $\mathrm{D}$ & Plasma & 69 & 30 & [56] \\
\hline let-7a/b & Lung & D, PG & Serum/plasma & 220 & 220 & [57] \\
\hline \multirow{2}{*}{ let-7b } & $\mathrm{HCC}$ & $\mathrm{D}, \mathrm{PG}$ & Serum & 120 & 30 & [58] \\
\hline & Ovarian & $\mathrm{D}$ & Serum & 18 & 12 & [59] \\
\hline \multirow{2}{*}{ let $-7 c$} & Lung & $\mathrm{D}$ & Plasma & 20 & 360 & [60] \\
\hline & Breast & $\mathrm{D}$ & Serum & 90 & 64 & [61] \\
\hline let-7c/i/f & Gastric & $\mathrm{D}$ & Serum & 214 & 424 & [62] \\
\hline let-7d & Prostate & PG & Plasma & 50 & 10 & [63] \\
\hline \multirow{2}{*}{ let-7e } & MM & PG & Serum & 121 & 30 & [64] \\
\hline & Thyroid & $\mathrm{D}$ & Serum & 95 & 44 & [65] \\
\hline \multirow{4}{*}{ let-7f } & Ovarian & $\mathrm{D}, \mathrm{PG}$ & Plasma & 360 & 200 & [66] \\
\hline & Colorectal & $\mathrm{D}$ & Feces & 51 & 26 & [54] \\
\hline & Lung & $\mathrm{D}, \mathrm{PG}$ & Plasma vesicles & 106 & 68 & [67] \\
\hline & $\mathrm{HCC}$ & $\mathrm{D}, \mathrm{PG}$ & Serum & 90 & 60 & [68] \\
\hline
\end{tabular}


Table 1. Cont.

\begin{tabular}{|c|c|c|c|c|c|c|}
\hline \multirow{2}{*}{ Circulating miRNA } & \multirow{2}{*}{ Cancer Type } & \multirow{2}{*}{ Type of Biomarker } & \multirow{2}{*}{ Body Fluid Type } & \multicolumn{2}{|c|}{ Cohort Size } & \multirow{2}{*}{ Reference } \\
\hline & & & & Cases & Controls & \\
\hline \multirow{2}{*}{ let-7i } & Lung & PG & Serum & 10 & 20 & [69] \\
\hline & Ovarian & $\mathrm{D}$ & Serum/plasma & 25 & 25 & [70] \\
\hline \multirow{7}{*}{$\operatorname{miR}-10$} & \multirow{3}{*}{ Breast } & $\mathrm{D}, \mathrm{PG}$ & Serum & 113 & - & [71] \\
\hline & & PG & Serum & 89 & 29 & [72] \\
\hline & & PG & Cerebrospinal & 16 & 15 & [73] \\
\hline & \multirow{2}{*}{ Lung } & $\mathrm{D}$ & Serum & 42 & 28 & [74] \\
\hline & & PG & Cerebrospinal & 28 & 15 & [73] \\
\hline & Glioblastoma & $\mathrm{D}$ & Cerebrospinal & 19 & 15 & [73] \\
\hline & Oesophageal & $\mathrm{D}$ & Serum & 50 & 50 & [75] \\
\hline \multirow{9}{*}{$m i R-16$} & Oral & $\mathrm{D}$ & Serum & 30 & 26 & [76] \\
\hline & \multirow{2}{*}{ Prostate } & $\mathrm{D}$ & Serum & 21 & 15 & [77] \\
\hline & & $\mathrm{D}$ & Serum & 73 & 20 & [78] \\
\hline & Breast & $\mathrm{D}$ & Serum & 76 & 76 & [79] \\
\hline & Osteosarcoma & $\mathrm{D}$ & Serum & 20 & 20 & [80] \\
\hline & \multirow{2}{*}{ Gastric } & D, PG & Plasma & 30 & 18 & [81] \\
\hline & & $\mathrm{D}, \mathrm{PG}$ & Serum & 50 & 47 & [82] \\
\hline & Liver & $\mathrm{D}$ & Serum & 90 & 60 & [68] \\
\hline & Oesophageal & D, PG & Plasma & 38 & 19 & [83] \\
\hline \multirow{3}{*}{$m i R-17$} & Gastric & D, PG & Serum & 50 & 47 & [82] \\
\hline & Liver & $\mathrm{D}$ & Serum & 90 & 60 & [68] \\
\hline & Oesophageal & $\mathrm{D}, \mathrm{PG}$ & Plasma & 38 & 19 & [83] \\
\hline \multirow{4}{*}{$m i R-18 a$} & Oesophageal & $\mathrm{D}$ & Serum & 106 & 54 & [84] \\
\hline & Gastric & $\mathrm{D}$ & Plasma & 104 & 65 & [85] \\
\hline & Breast & $\mathrm{D}, \mathrm{PD}$ & Serum & 108 & 75 & [86] \\
\hline & Colorectal & $\mathrm{D}$ & Stool & 198 & 198 & [87] \\
\hline$m i R-17 / 19 a$ & Melanoma & PD & Plasma & 13 & 13 & [88] \\
\hline \multirow{7}{*}{$m i R-19 a$} & & PD & Serum & 30 & 38 & [89] \\
\hline & Breast & $\mathrm{D}$ & Serum & 63 & 21 & [90] \\
\hline & & $\mathrm{D}, \mathrm{PG}$ & Serum & 113 & - & [71] \\
\hline & Bladder & $\mathrm{D}$ & Plasma & 50 & 50 & [91] \\
\hline & Colorectal & D, PG & Serum & 90 & 12 & [92] \\
\hline & MM & D,PG,PD & Serum & 108 & 56 & [93] \\
\hline & Lung & $\mathrm{D}, \mathrm{PG}$ & Serum & 201 & 103 & [94] \\
\hline \multirow{2}{*}{$m i R-19 b$} & Gastric & D, PG & Plasma & 30 & 18 & [81] \\
\hline & Lung & D, PG & Serum & 94 & 94 & [95] \\
\hline \multirow{5}{*}{$m i R-20 a$} & Prostate & $\mathrm{D}$ & Plasma & 82 & - & [96] \\
\hline & Lung & $\mathrm{D}$ & Plasma & 126 & 60 & [97] \\
\hline & Osteosarcoma & $\mathrm{D}$ & Serum & 20 & 20 & [80] \\
\hline & Colorectal & $\mathrm{D}$ & Feces & 397 & 198 & [98] \\
\hline & Esophageal & $\mathrm{D}$ & Plasma & 70 & 40 & [99] \\
\hline \multirow{2}{*}{$m i R-17 /-92$} & Colorectal & PD & Serum & 37 & 7 & [100] \\
\hline & Colorectal & $\mathrm{D}$ & Plasma & 90 & 90 & [101] \\
\hline$m i R-92$ & Ovarian & $\mathrm{D}$ & Serum & 28 & 15 & [102] \\
\hline \multirow{2}{*}{$m i R-92 a$} & Colorectal & $\mathrm{D}$ & Plasma & 152 & 75 & [103] \\
\hline & Leukemia & $\mathrm{D}$ & Plasma & 77 & 16 & [104] \\
\hline
\end{tabular}


Table 1. Cont.

\begin{tabular}{|c|c|c|c|c|c|c|}
\hline \multirow{2}{*}{ Circulating miRNA } & \multirow{2}{*}{ Cancer Type } & \multirow{2}{*}{ Type of Biomarker } & \multirow{2}{*}{ Body Fluid Type } & \multicolumn{2}{|c|}{ Cohort Size } & \multirow{2}{*}{ Reference } \\
\hline & & & & Cases & Controls & \\
\hline$m i R-92 a / b$ & Prostate & $\mathrm{D}$ & Serum & 21 & 15 & [77] \\
\hline \multirow{4}{*}{$m i R-106 a$} & Gastric & D, PG & Plasma & 48 & 22 & [105] \\
\hline & \multirow{3}{*}{ Colorectal } & $\mathrm{D}$ & Feces & 117 & 107 & [106] \\
\hline & & $\mathrm{D}$ & Plasma & 100 & 79 & [107] \\
\hline & & PG & Serum & 175 & 130 & [108] \\
\hline$m i R-17 /-106 a / b$ & Gastric & $\mathrm{D}$ & Plasma & 69 & 30 & [56] \\
\hline$m i R-17 /-106 b$ & Gastric & $\mathrm{D}$ & Serum & 72 & 36 & [109] \\
\hline \multirow{6}{*}{$m i R-106 b$} & \multirow{2}{*}{ Liver } & $\mathrm{D}$ & Plasma & 47 & 61 & [110] \\
\hline & & $\mathrm{D}$ & Serum exosomes & 20 & 40 & [111] \\
\hline & Breast & D, PG & Plasma & 173 & 50 & [112] \\
\hline & Gastric & $\mathrm{D}, \mathrm{PG}$ & Plasma & 20 & 20 & [113] \\
\hline & Bladder & $\mathrm{D}$ & Urine & 112 & 78 & [114] \\
\hline & Ovarian & $\mathrm{D}$ & Serum & 31 & 31 & [115] \\
\hline \multirow{42}{*}{$m i R-21$} & \multirow{4}{*}{ DLBCL } & $\mathrm{D}$ & Serum & 60 & 43 & [11] \\
\hline & & D,PD,PG & Serum & 112 & 45 & [116] \\
\hline & & D & Serum & 60 & 43 & [11] \\
\hline & & $\mathrm{D}, \mathrm{PD}, \mathrm{PG}$ & Serum & 62 & 50 & [117] \\
\hline & HL & $\mathrm{D}$ & Plasma & 42 & 20 & [118] \\
\hline & $\begin{array}{c}\text { CNS } \\
\text { lymphoma }\end{array}$ & D, PG & Serum & 37 & 53 & [119] \\
\hline & \multirow{8}{*}{ Breast } & $\mathrm{D}$ & Plasma & 14 & 8 & [120] \\
\hline & & $\mathrm{D}, \mathrm{PG}$ & Serum & 62 & 10 & [121] \\
\hline & & $\mathrm{D}, \mathrm{PG}$ & Serum & 30 & 60 & [122] \\
\hline & & $\mathrm{D}, \mathrm{PG}$ & Serum & 50 & 82 & [123] \\
\hline & & PG & Serum & 326 & 223 & [124] \\
\hline & & $\mathrm{D}$ & Plasma & 114 & 116 & [125] \\
\hline & & $\mathrm{D}$ & Urine & 24 & 24 & [126] \\
\hline & & PG & Serum & 113 & - & [71] \\
\hline & \multirow{7}{*}{ Gastric } & $\mathrm{D}$ & Plasma & 69 & 30 & {$[56]$} \\
\hline & & $\mathrm{D}, \mathrm{PG}$ & Plasma & 42 & - & [127] \\
\hline & & PG & Serum & 103 & - & [128] \\
\hline & & PG & Serum & 79 & - & [129] \\
\hline & & PG & Serum & 64 & 64 & [130] \\
\hline & & PG & Plasma & 69 & - & [131] \\
\hline & & $\mathrm{D}$ & Serum & 50 & 50 & [132] \\
\hline & \multirow[b]{2}{*}{ Glioblastoma } & PG & Serum & 30 & 30 & [39] \\
\hline & & $\mathrm{D}$ & Plasma & 10 & 10 & [133] \\
\hline & \multirow{3}{*}{ Ovarian } & $\mathrm{D}$ & Serum & 28 & 15 & [102] \\
\hline & & $\mathrm{D}, \mathrm{PG}$ & Serum & 94 & 40 & [134] \\
\hline & & $\mathrm{D}$ & Serum & 60 & 10 & [135] \\
\hline & \multirow{7}{*}{ Pancreatic } & $\mathrm{D}$ & Plasma & 49 & 36 & [136] \\
\hline & & $\mathrm{D}, \mathrm{PG}$ & Plasma & 32 & 30 & [137] \\
\hline & & $\mathrm{D}$ & Plasma & 24 & 24 & [138] \\
\hline & & $\mathrm{D}$ & Stool & 30 & 15 & [139] \\
\hline & & $\mathrm{D}$ & Serum & 22 & 14 & [140] \\
\hline & & $\mathrm{D}$ & Plasma & 30 & 26 & [141] \\
\hline & & $\mathrm{D}$ & Saliva & 7 & 4 & [142] \\
\hline & & PD & Plasma & 82 & - & [96] \\
\hline & Prostate & PD & Serum & 56 & - & [143] \\
\hline & & PD & Serum & 37 & 7 & [100] \\
\hline & & $\mathrm{D}, \mathrm{PG}$ & Serum & 40 & 40 & [144] \\
\hline & & $\mathrm{D}$ & Serum & 160 & 77 & [144] \\
\hline & Colorectal & $\mathrm{D}, \mathrm{PG}$ & Serum & 186 & 96 & [145] \\
\hline & & $\mathrm{D}$ & Serum & 200 & 130 & [146] \\
\hline & & PG & Serum & 102 & - & [147] \\
\hline & & $\mathrm{D}$ & Serum & 56 & 197 & [148] \\
\hline
\end{tabular}


Table 1. Cont.

\begin{tabular}{|c|c|c|c|c|c|c|}
\hline \multirow{2}{*}{ Circulating miRNA } & \multirow{2}{*}{ Cancer Type } & \multirow{2}{*}{ Type of Biomarker } & \multirow{2}{*}{ Body Fluid Type } & \multicolumn{2}{|c|}{ Cohort Size } & \multirow{2}{*}{ Reference } \\
\hline & & & & Cases & Controls & \\
\hline \multirow{16}{*}{$m i R-21$} & Melanoma & PD & Plasma & 13 & 13 & [88] \\
\hline & \multirow{4}{*}{ Lung } & $\mathrm{D}, \mathrm{PG}$ & Plasma & 25 & 25 & [97] \\
\hline & & $\mathrm{D}, \mathrm{PG}$ & Serum & 152 & 300 & [149] \\
\hline & & $\mathrm{D}$ & BAL + sputum & 21 & 10 & [150] \\
\hline & & $\mathrm{D}, \mathrm{PG}$ & Serum & 80 & 60 & [151] \\
\hline & Neck & $\mathrm{D}$ & Plasma & 50 & 36 & [152] \\
\hline & \multirow{3}{*}{ Oesophageal } & $\mathrm{D}$ & Plasma & 50 & 20 & [153] \\
\hline & & $\mathrm{D}$ & Saliva & 39 & 19 & [154] \\
\hline & & $\mathrm{D}, \mathrm{PG}$ & Plasma & 38 & 19 & [83] \\
\hline & \multirow{4}{*}{ Liver } & $\mathrm{D}$ & Serum & 52 & 43 & [155] \\
\hline & & PG & Serum & 224 & - & [156] \\
\hline & & $\mathrm{D}, \mathrm{PG}$ & Serum & 30 & 60 & [157] \\
\hline & & $\mathrm{D}$ & Serum & 23 & 17 & [158] \\
\hline & Biliary tract & $\mathrm{D}$ & Plasma & 94 & 73 & [159] \\
\hline & Nasopharyngeal & $\mathrm{D}$ & Plasma & 217 & 73 & [160] \\
\hline & Osteosarcoma & $\mathrm{D}, \mathrm{PG}$ & Plasma & 40 & 40 & [161] \\
\hline$m i R-29 a / b / c$ & Osteosarcoma & $\mathrm{D}, \mathrm{PG}$ & Serum & 80 & 80 & [162] \\
\hline \multirow{7}{*}{$m i R-29 a$} & \multirow{3}{*}{ Colorectal } & $\mathrm{D}$ & Plasma & 152 & 75 & [103] \\
\hline & & $\mathrm{D}$ & Serum & 38 & 36 & [163] \\
\hline & & $\mathrm{D}$ & Serum & 30 & 26 & [164] \\
\hline & \multirow{2}{*}{ Breast } & $\mathrm{D}$ & Serum & 63 & 90 & [165] \\
\hline & & $\mathrm{D}$ & Serum & 20 & 20 & [166] \\
\hline & Oral & $\mathrm{D}$ & Serum & 30 & 26 & [76] \\
\hline & Ovarian & $\mathrm{D}$ & Serum & 28 & 15 & [102] \\
\hline$m i R-29 b$ & Colorectal & $\mathrm{D}, \mathrm{PG}$ & Serum & 55 & 55 & [167] \\
\hline \multirow{3}{*}{$m i R-29 c$} & Colorectal & PG & Serum & 103 & 37 & [168] \\
\hline & Lung & $\mathrm{D}$ & Serum & 70 & 48 & [169] \\
\hline & Nasopharyngeal & $\mathrm{D}$ & Serum & 160 & 143 & [170] \\
\hline \multirow{2}{*}{$m i R-30 a$} & Lung & $\mathrm{D}$ & Plasma & 60 & 75 & [171] \\
\hline & Esophageal & $\mathrm{D}$ & Serum exosomes & 18 & 29 & [172] \\
\hline \multirow{3}{*}{$m i R-30 c$} & \multirow{2}{*}{ Prostate } & $\mathrm{D}$ & Plasma & 105 & 115 & [173] \\
\hline & & $\mathrm{D}$ & Plasma & 59 & 27 & [174] \\
\hline & Lung & $\mathrm{D}$ & Serum & 80 & 40 & [175] \\
\hline \multirow{2}{*}{$m i R-30 d$} & \multirow{2}{*}{ Lung } & PG & Serum & 82 & 50 & [176] \\
\hline & & PG & Serum & 303 & - & [177] \\
\hline miR-30e & Liver & $\mathrm{D}$ & Serum & 39 & 31 & [178] \\
\hline \multirow{2}{*}{$m i R-34 a$} & Breast & $\mathrm{D}, \mathrm{PG}$ & Serum & 89 & 29 & [74] \\
\hline & Lung & $\mathrm{D}$ & Blood & 22 & 27 & [179] \\
\hline \multirow{2}{*}{$m i R-34 b$} & Prostate & $\mathrm{D}$ & Serum & 21 & 15 & [77] \\
\hline & Osteosarcoma & $\mathrm{D}$ & Plasma & 133 & 133 & [180] \\
\hline$m i R-34 b / c$ & Breast & $\mathrm{D}$ & Serum & 15 & 15 & [181] \\
\hline$m i R-34 c$ & Lung & $\mathrm{D}$ & Serum & 17 & 19 & [182] \\
\hline \multirow{4}{*}{$m i R-125 a$} & Oral & $\mathrm{D}$ & Saliva & 50 & 62 & [183] \\
\hline & Lung & $\mathrm{D}$ & Serum & 70 & 70 & [184] \\
\hline & Breast & PG & Serum & 300 & - & [185] \\
\hline & Liver & PG & Serum & 120 & 255 & [186] \\
\hline
\end{tabular}


Table 1. Cont.

\begin{tabular}{|c|c|c|c|c|c|c|}
\hline \multirow{2}{*}{ Circulating miRNA } & \multirow{2}{*}{ Cancer Type } & \multirow{2}{*}{ Type of Biomarker } & \multirow{2}{*}{ Body Fluid Type } & \multicolumn{2}{|c|}{ Cohort Size } & \multirow{2}{*}{ Reference } \\
\hline & & & & Cases & Controls & \\
\hline \multirow{8}{*}{$m i R-125 b$} & \multirow{2}{*}{ Breast } & PD & Serum & 56 & 10 & [187] \\
\hline & & $\mathrm{D}$ & Plasma & 197 & 142 & [125] \\
\hline & \multirow{2}{*}{ Lung } & $\mathrm{D}, \mathrm{PG}$ & Serum & 193 & 110 & [188] \\
\hline & & PG, PD & Serum & 260 & 260 & [189] \\
\hline & Oral & $\mathrm{D}$ & Plasma & 85 & 46 & [190] \\
\hline & Colorectal & $\mathrm{D}$ & Serum & 160 & 77 & [191] \\
\hline & Glioma & $\mathrm{D}$ & Serum & 33 & 33 & [192] \\
\hline & Melanoma & $\mathrm{D}$ & Serum exosomes & 21 & 35 & [193] \\
\hline \multirow{15}{*}{$m i R-155$} & \multirow{6}{*}{ Breast } & $\mathrm{D}$ & Serum & 63 & 21 & [90] \\
\hline & & $\mathrm{D}$ & Plasma/serum & 184 & 75 & [194] \\
\hline & & $\mathrm{D}$ & Serum & 20 & 10 & [195] \\
\hline & & $\mathrm{D}$ & Serum & 103 & 55 & [196] \\
\hline & & $\mathrm{D}, \mathrm{PG}$ & Serum & 89 & 29 & [74] \\
\hline & & PG & Serum & 32 & 120 & [197] \\
\hline & Colorectal & $\mathrm{D}, \mathrm{PG}$ & Serum & 146 & 60 & [198] \\
\hline & \multirow{2}{*}{ Lung } & $\mathrm{D}$ & Serum & 36 & 32 & [199] \\
\hline & & $\mathrm{D}$ & Serum/plasma & 220 & 220 & [57] \\
\hline & Esophageal & D, PG & Plasma & 60 & 60 & [200] \\
\hline & AML & $\mathrm{D}$ & Serum & 140 & 135 & [201] \\
\hline & \multirow{2}{*}{ DLBCL } & $\mathrm{D}$ & Serum & 75 & 77 & [202] \\
\hline & & $\mathrm{D}$ & Serum & 60 & 43 & [11] \\
\hline & CLL & PG, PD & Plasma & 228 & - & [203] \\
\hline & ATL & PG & Plasma & 35 & - & [204] \\
\hline$m i R-200 a / b / c / 141$ & Ovarian & $\mathrm{D}$ & Serum exosomes & 50 & 20 & [135] \\
\hline \multirow{2}{*}{$m i R-200 a / b / c$} & \multirow{2}{*}{ Ovarian } & $\mathrm{D}, \mathrm{PG}$ & Serum & 70 & 70 & [205] \\
\hline & & $\mathrm{D}$ & Serum & 28 & 28 & [206] \\
\hline$m i R-200 c / 141$ & Breast & $\mathrm{D}, \mathrm{PG}$ & Blood & 57 & 20 & [207] \\
\hline$m i R-200 c / 141$ & Ovarian & $\mathrm{D}, \mathrm{PG}$ & Serum & 93 & 50 & [208] \\
\hline$m i R-200 a$ & Oral & $\mathrm{D}$ & Saliva & 50 & 62 & [183] \\
\hline$m i R-200 b$ & Prostate & PG, PD & Serum/plasma & 97 & - & [209] \\
\hline \multirow{6}{*}{$m i R-200 c$} & \multirow{2}{*}{ Colorectal } & $\mathrm{D}$ & Plasma & 78 & 86 & [210] \\
\hline & & PG & Serum & 206 & 24 & [211] \\
\hline & \multirow{2}{*}{ Gastric } & $\mathrm{D}, \mathrm{PG}$ & Serum & 98 & 100 & [212] \\
\hline & & $\mathrm{D}, \mathrm{PG}$ & Blood & 52 & 15 & [213] \\
\hline & Lung & $\mathrm{D}, \mathrm{PG}$ & Serum & 70 & 44 & [214] \\
\hline & Esophageal & PG, PD & Serum & 64 & - & [215] \\
\hline \multirow{9}{*}{$m i R-141$} & Urinary tract & $\mathrm{D}$ & Serum & 44 & 34 & [216] \\
\hline & Lung & $\mathrm{D}$ & Serum & 42 & 28 & [74] \\
\hline & \multirow{6}{*}{ Prostate } & $\mathrm{D}$ & Serum & 25 & 25 & [12] \\
\hline & & PG & Serum & 113 & - & [217] \\
\hline & & $\mathrm{D}$ & Serum & 21 & 15 & {$[77]$} \\
\hline & & $\mathrm{D}$ & Plasma vesicles & 78 & 28 & [218] \\
\hline & & $\mathrm{D}$ & Serum exosomes & 71 & 80 & [219] \\
\hline & & PG & Serum & 30 & 26 & [220] \\
\hline & Colorectal & PG & Plasma & 185 & 76 & [221] \\
\hline$m i R-429$ & Lung & $\mathrm{D}, \mathrm{PG}$ & Serum & 70 & 48 & [169] \\
\hline
\end{tabular}


Table 1. Cont.

\begin{tabular}{|c|c|c|c|c|c|c|}
\hline \multirow{2}{*}{ Circulating miRNA } & \multirow{2}{*}{ Cancer Type } & \multirow{2}{*}{ Type of Biomarker } & \multirow{2}{*}{ Body Fluid Type } & \multicolumn{2}{|c|}{ Cohort Size } & \multirow{2}{*}{ Reference } \\
\hline & & & & Cases & Controls & \\
\hline \multirow{13}{*}{ miR-210 } & DLBCL & $\mathrm{D}$ & Serum & 60 & 43 & [11] \\
\hline & \multirow{2}{*}{ Pancreatic } & $\mathrm{D}$ & Plasma & 49 & 36 & [136] \\
\hline & & $\mathrm{D}$ & Plasma & 22 & 25 & [222] \\
\hline & \multirow{2}{*}{ Renal } & $\mathrm{D}$ & Serum & 78 & 42 & [223] \\
\hline & & $\mathrm{D}$ & Serum & 34 & 23 & [224] \\
\hline & Breast & PG, PD & Plasma & 69 & 43 & [225] \\
\hline & \multirow{3}{*}{ Pancreatic } & $\mathrm{D}$ & Saliva & 7 & 4 & [142] \\
\hline & & $\mathrm{D}, \mathrm{PG}$ & Pancreatic juice & 6 & 6 & [226] \\
\hline & & $\mathrm{D}$ & Plasma & 30 & 26 & [141] \\
\hline & \multirow[b]{2}{*}{ Bladder } & $\mathrm{D}, \mathrm{PG}$ & Serum & 168 & 104 & [227] \\
\hline & & $\mathrm{D}$ & Urine & 94 & 56 & [228] \\
\hline & Glioma & $\mathrm{D}, \mathrm{PG}$ & Serum & 136 & 50 & [229] \\
\hline & Liver & PD, PG & Serum & 113 & 39 & [230] \\
\hline \multirow{9}{*}{$m i R-221$} & \multirow{2}{*}{ Colorectal } & $\mathrm{D}$ & Plasma & 103 & 37 & [231] \\
\hline & & $\mathrm{D}$ & Stool & 198 & 198 & [87] \\
\hline & Prostate & PG & Plasma & 82 & - & [96] \\
\hline & Leukemia & $\mathrm{D}$ & Plasma & 79 & 37 & [232] \\
\hline & Liver & $\mathrm{D}$ & Serum & 20 & 40 & [111] \\
\hline & Larynx & $\mathrm{D}$ & Plasma & 30 & 30 & [233] \\
\hline & Glioma & $\mathrm{D}, \mathrm{PG}$ & Plasma & 50 & 51 & [234] \\
\hline & Melanoma & $\mathrm{D}, \mathrm{PG}$ & Serum & 72 & 54 & [235] \\
\hline & Renal & PG & Plasma & 77 & - & [236] \\
\hline \multirow{12}{*}{$m i R-375$} & Breast & PG & Serum & 68 & - & [237] \\
\hline & \multirow{2}{*}{ Lung } & $\mathrm{D}, \mathrm{PG}$ & Plasma & 217 & 217 & [238] \\
\hline & & PG & Serum & 113 & - & [217] \\
\hline & \multirow{4}{*}{ Prostate } & PG & Serum & 47 & 72 & [218] \\
\hline & & PG & Serum & 84 & - & [239] \\
\hline & & PG & Plasma & 100 & - & [240] \\
\hline & & $\mathrm{D}$ & Plasma & 78 & 28 & [218] \\
\hline & \multirow{3}{*}{ Oesophageal } & $\mathrm{D}$ & Plasma & 38 & 19 & [83] \\
\hline & & PG & Serum & 194 & 94 & [241] \\
\hline & & $\mathrm{D}$ & Plasma & 50 & 20 & [153] \\
\hline & Liver & $\mathrm{D}$ & Serum & 78 & 156 & [242] \\
\hline & Colorectal & $\mathrm{D}$ & Plasma & 88 & 40 & [243] \\
\hline
\end{tabular}

\section{1. let-7 Family (let-7a, $-7 b,-7 c,-7 e,-7 f,-7 i)$}

There are 13 different let-7 family members in humans: let-7a-1, 7a-2, 7a-3, 7b, 7c, 7d, 7e, 7f-1,7f-2, 7g, $7 i, m i R-98$, and $m i R-202$ [244]. Differential expression of let-7 family members has been described to be downregulated in a wide variety of cancers such as melanoma, pancreatic cancer, prostate cancer, and sarcoma, although some, including lymphoma, mesothelioma, and breast cancer, have been shown to be upregulated; thus, the let-7 family is generally regarded as a tumor suppressor [245]. let-7 has been shown to be a direct regulator of some important oncogenes, such as the three RAS genes [246,247], HMGA2 [248,249], STAT3 [250], UHRF2 [251], and MYC [252-254]; additionally, let-7 family targets cell cycle and cell proliferation genes [255-257]; finally, apoptosis is also shown to be regulated by let-7 family, through CASP3 targeting [258]. RNase III nuclease, known to process pre-miRs, was also confirmed as a direct target of the let-7 family, so they might regulate their own processing $[259,260]$.

let-7 family members have been identified differentially expressed and therefore have been proposed as diagnostic tools in serum/plasma of many cancer types including lung cancer (let-7a, 
let-7c, let-7f) [57,60,67], prostate cancer (let-7a) [52], gastric cancer (let-7a, let-7c, let-7i, let-7f) [56,62], ovarian cancer (let-7b, let-7f, let-7i) [59,66,70], hepatocellular carcinoma (HCC) (let-7b, let-7f) [58,68], breast cancer (let-7c, let-7b, let-7g) [61,261], acute myeloid leukemia (AML) (let-7b, let-7d) [262], thyroid carcinoma (let-7e) [65], and colorectal cancer (CRC) (let-7a) [53,54]. Recently, let-7f has also been detected as deregulated in the feces of CRC patients [54]. However, their potential as prognostic biomarkers has also been highlighted in several cancer types such as myelodisplasia (let-7a) [55], lung cancer (let-7b, let-7f, let-7i) [57,67,69], hepatocellular carcinoma (let-7b, let-7f) [58,68], multiple myeloma (let-7e) [64], prostate cancer (let-7d) [63], ovarian cancer (let-7f) [66], and breast cancer (miR-202) [263]. In general, low let-7 levels are associated with poor prognosis including overall survival, early recurrence, and tumor size.

\section{2. $m i R-10 b$}

miR-10b acts as a metastasis driver in many different types of cancers such as breast cancer [264], glioma [265], and oesophageal cancer [266], among others, specifically promoting cell mobility and invasiveness. Validated targets of this miRNA include SDC1 [267], HOXD10 [264,265,268,269], KLF4 [266,270], MICB [271], and CDH1 [272]. It also regulates E2F1-mediated transcription through $p 21 / C D K N 1 A$ regulation [273] and important cell cycle regulators such as BUB1, PLK1, and CCNA2 [274].

Circulating $m i R-10 b$ levels have been described as being upregulated in patients with ovarian cancer [30], lung cancer [29], oesophageal [75], and glioblastoma [73] compared to healthy controls. Consistent with this, $m i R-10 b$ is increased in plasma from metastatic breast cancer patients $[27,28]$ and in the cerebrospinal fluid of patients with brain metastasis of both breast and lung cancer [73].

\section{3. $m i R-16$}

miR-16 has an important role in regulating apoptosis in different cancer types including lung, breast, liver, glioblastoma, and squamous cell carcinoma through targeting FEAT/METTL13 [275], RPS6KB1, IGF1R [276], CCND1 [277], BCL2 [278], RECK, and/or SOX6 [279]. This miRNA is also an important regulator of cell cycle molecules including FG2F, CCNE1, and E2F1 [280-282], as well as cell autophagy (mTORC2) and metastasis (SOX5) [283,284].

Circulating $m i R-16$ has been described significantly differentially expressed in patients compared with healthy controls in several cancers: oral cancer [76], breast cancer [79], prostate cancer [36], osteosarcoma [80], gastric cancer [81,82], liver carcinoma [68], and oesophageal carcinoma [83]. Furthermore, miR-16 is also associated with prognosis and tumor size in gastric cancer [81,82], hepatocellular carcinoma [68], and esophageal squamous cell carcinoma (ESCC) [83].

\subsection{The miR-17 92 Cluster}

Over-expression of the miR-17 92 cluster is a key oncogenic event in many cancer types, and overexpression in murine models result in tumor formation. This cluster is composed of different miRNAs: $m i R-17, m i R-18 a, m i R-19 a, m i R-19 b, m i R-20 a, m i R-92$, and $m i R-106 a / b$ with a variety of related functions, primarily targeting tumor suppressor molecules and pathways such as PTEN and RB1 [285,286], and molecules in the TGF $\beta$ signaling pathway such as TGFBR2, SMAD2, and SMAD4 [287-289]. These miRNAs also target senescence ( $p 21 / C D K N 1 A)$ [290,291], metastasis (DLC1 and TIMP2) [292-294], cell cycle regulation (E2F family members, RB1 and $p 21 / C D K N 1 A$ ), and angiogenesis (THBS1 and CTGF) [295-297].

Circulating members of the $m i R-17 \sim 92$ cluster have been widely described as being deregulated in many cancer types including colorectal cancer [56,87,92,98,101,103,105-107,231,298], gastric cancer [56,81,85,109,113], squamous cell carcinoma [84], breast cancer [86,90,114], bladder cancer [91], hematological malignancies [93,104,117,202,299,300], lung cancer [94,95,97], prostate cancer [77], osteosarcoma [80], oesophageal carcinoma [99], ovarian cancer [81,115], and hepatocellular carcinoma [110,111,301]. They have also been shown to have prognostic value in colorectal 
cancer [92,100,108], sporadic melanoma [88], breast cancer [71,112], bladder cancer [91], multiple mieloma [93,104,299,300], lung cancer [94], and prostate cancer [96]. Moreover, levels of circulating miR-17 92 miRNAs have been associated with the response to chemotherapy (i.e., predictive biomarkers) in both breast cancer [89] and multiple myeloma [93].

\section{5. $m i R-21$}

$m i R-21$ acts mainly as an oncogene ("onco-miR") because most of its target genes are tumor suppressors. The list of these target genes is extensive, and they are related to all hallmarks of cancer [302]. One of the principal miR-21 targets is PDCD4, which is a tumor suppressor gene that inhibits PMA-induced neoplastic transformation [303], tumor promotion and progression [304], and invasion and intravasation [305]. miR-21 targets multiple components of TP53, TGFB1, and mitochondrial apoptosis tumor suppressive pathways (including HNRPK and TP63) [306]. Other targets of miR-21 have been related mainly with apoptosis, cell growth, migration, and invasion, such as BCL2 [307], PTEN [307-309], RECK [310], RHOB [311], and TPM1 [312], among others.

Circulating miR-21 has been described in a lot of different cancers as a diagnostic, predictive, and/or prognosis biomarker. Some of these are hematological cancers [116,117], breast cancer [124,125], gastric cancer [128,130], ovarian cancer [134,135], pancreatic cancer [136,141], colorectal cancer $[100,145]$, lung cancer $[97,149]$, and liver cancer $[155,156]$, among others.

\subsection{The miR-29 Family (miR-29a, -29b, and -29c)}

The miR-29 family members act as tumor suppressors, and their downregulation is associated with many cancer types including leukemia [313-315], melanoma [316], liver cancer [317,318], colon cancer [319], cervical cancer [320], lung cancer [321], and prostate cancer [322]. In many studies, downregulation of miR-29 has correlated with more aggressive forms of cancer and shorter overall survival $[316,321,323]$. It has been demonstrated to directly target genes involved in the control of the cell cycle (CDK6) [319,320,323] and apoptosis (MCL1, BCL2 and FHIT) [315,319,321], as well as genes that promote cell migration and invasion ( $L A M C 1, C D C 42)$ [322,324]. Furthermore, the miR-29 family target genes such as PIK3R1 and CDC42 that normally suppress TP53 [324].

Differential expression of $m i R-29$ family members in plasma/serum has been observed in several cancer types. The expression levels of all the miR-29 family members were upregulated in sera of patients with osteosarcoma. In particular, $m i R-29 a$ and $m i R-29 b$ were associated with poor prognosis [162]. $m i R-29 a$ has been shown to be upregulated in colorectal cancer and therefore has been proposed as a potential non-invasive biomarker for early detection of colorectal cancer [101,103,164,231], also involving liver metastasis [163]. It has also been found to be upregulated in breast cancer $[165,166]$ and downregulated in oral and ovarian cancer, compared with healthy controls [76,102]. Similarly, serum levels of $m i R-29 b$ have been proposed as potential biomarkers for diagnosis and prognosis of colorectal cancer [167], whereas $m i R-29 c$ could be useful as a predictor of postoperative early relapse [168]. However, it was found to be downregulated in serum of nasopharyngeal carcinoma patients, compared with controls [170].

\subsection{The miR-30 Family (miR-30a, -30b, -30c, -30d, and -30e)}

Similar to the miR-29 family, miR-30 family members appear to act primarily as tumor suppressors in several cancer types such as ovarian cancer, breast cancer, non-small cell lung cancer (NSCLC), and colorectal carcinoma [325-330], although they have also been reported as oncogenes [331]. Several genes have been described to be regulated by the miR-30 family, such as some epithelial-to-mesenchymal transition (EMT)-associated genes [332], anti-apoptotic protein AVEN [333], and DLL4 which has a fundamental role in angiogenesis [334].

Members of the miR-30 family have been identified differentially regulated in body fluids, but their potential as biomarkers has mostly been reported in combinations with other miRNAs. For example, a blood test based upon a combination of the levels of five miRNAs including miR-30c has been described 
to effectively differentiate prostate cancer patients from benign prostatic hyperplasia (BPH) patients and healthy controls [173]. In addition, the combination of four plasma circulating miRNAs, including $m i R-30 c$ and serum PSA, has a greater potential to be used as a noninvasive diagnostic biomarker for prostate cancer screening than PSA testing alone [174]. Similar studies have been reported for miR-30c and $m i R-30 a-3 p$ in lung adenocarcinoma [171,175], miR-30a in esophageal adenocarcinoma [172], and $m i R-30 d$ in lung cancer [176]. In hepatocellular carcinoma, miR-30e has been recently found to be downregulated in serum when compared with healthy controls [178], and, in lung cancer, high levels of miR-30d in serum have been associated with a shorter overall survival [176,177].

\subsection{The miR-34 Family (miR-34a, $-34 b$, and $-34 c)$}

Members of the miR-34 family are well known to regulate cell cycle, senescence, apoptosis, and invasiveness in cancer, and deregulation of $m i R-34 a$ has been reported in several types of cancers [335,336]. The miR-34 family targets multiple TP53 inhibitor genes (MDM4, SIRT1, MTA2, $H D A C 1$, and $Y Y 1$ ) and promotes proliferation arrest and induction of apoptosis by targeting $M Y C$, $C D K 6$, and $M E T$. These genes encode factors required for G1/S transition $(M Y C, E 2 F, C D K 4$, and $C D K 6)$, anti-apoptotic proteins (BCL2, SIRT1), and proteins involved in invasion (MET) [337]. It has also been reported to target pluripotency genes such as NANOG, SOX2, and MYCN [338,339] and components of Wnt signaling pathways [340,341] and notch signaling pathways [342,343], which regulate growth, epithelial-mesenchymal transition (EMT), and metastasis.

Elevated levels of $m i R-34 a$ in serum can discriminate between breast cancer patients and healthy controls, and are also associated with the presence of overt metastasis [72,237]. High levels of circulating $m i R-34 a$ have also been observed in ovarian and lung cancer [72,74,179], and miR-34b has been found to be upregulated in serum from prostate cancer patients [77]. In osteosarcoma patients, $m i R-34 b$ levels were found to be downregulated when compared with controls, and these expression levels were significantly decreased in the metastatic patients [180]. Similarly, downregulation of circulating $m i R-34 c$ in serum of NSCLC patients and $m i R-34 b / c$ in serum of breast cancer patients has been reported and might have potential as biomarkers for the diagnosis of these pathologies [181,182].

\subsection{The miR-125 Family (miR-125a and -125b)}

miR-125 has been shown to act as a tumor-suppressor in several cancers including ovarian cancer [313,344], bladder cancer [345], breast cancer [346,347], hepatocellular carcinoma [348-350], melanoma [351], cutaneous squamous cell carcinoma [352], and osteosarcoma [353]. miR-125 targets several genes associated with carcinogenesis such as transcription factors (STAT3 and E2F3) [345,353], matrix-metalloprotease (MMP11 and MMP13) [348,352], members of the BCL2 family [354,355], and growth factors (VEGFA) [348].

Deregulated levels of $m i R-125 a$ were present in the saliva of oral squamous cell carcinoma (OSCC) patients and in serum of NSCLC patients compared with healthy controls [183,184]. In a similar way, $m i R-125 b$ levels were significantly lower in glioma patients and in serum-derived exosomes of melanoma patients [192,193]. In addition, low circulating levels of miR-125a have been associated with poor prognosis in both breast cancer and hepatocellular carcinoma $[185,186]$. In contrast, miR-125b was found to be upregulated in the plasma and serum of metastatic prostate cancer patients [356], breast cancer [125], OSCC [190], colorectal cancer [191], and NSCLC [188], in comparison with healthy controls, and to be associated with poor prognostic outcome and chemotherapeutic resistance in this cancer [187-189].

\subsection{0. $m i R-155$}

miR-155 is involved in both physiological (hematopoiesis andimmune response) and pathological processes. The oncogenic role of $m i R-155$ is well established in both hematological malignances as well as solid cancers such as breast cancer, where its overexpression is generally correlated with poor prognosis [357,358]. Validated miR-155 target genes are present in multiple pathways associated with 
cancer and cancer progression, including EMT (SMAD5), proliferation (SOCS1, INPP5D, and CSF1R), block of differentiation (SPI1, CEBPB), and apoptosis (CASP3, FADD, APAF1, and FOXO3A) [359-367].

In many studies, differentially expressed levels of circulating miR-155 have been identified, including breast cancer [90,194-196], colorectal cancer [198], lung cancer [57,199], AML [201], diffuse large B-cell lymphoma (DLBCL) [11,202], and esophageal cancer [200], making it a potential non-invasive diagnostic biomarker for early detections in these pathologies. In fact, a biosensor for miR-155 detection in plasma has recently been developed for the diagnosis of breast cancer [368]. Elevated levels of miR-155 are also related to overt metastasis in breast cancer [72,197], and these high levels have also been identified not only in blood but also in the urine of breast cancer patients [126]. In addition, miR-155 has been also suggested as a prognostic biomarker in chronic lymphocytic leukemia (CLL) and adult T-cell leukemia (ATL) [203,204], and as a predictive biomarker to response to therapy in CLL [203].

\subsection{The miR-200 Family (miR-200a, -200b, -200c, -141, and -429)}

The miR-200 family is believed to play crucial roles in both cancer initiation and metastasis-in particular, in epithelial-mesenchymal transition (EMT) - primarily through the targeting of ZEB1 and ZEB2 transcription factors [369,370]. It has also been associated with angiogenesis by the targeting of VEGFA and VEGF receptors [371,372] and pro-angiogenic ligands such as CXCL8 and CXCL1 [373].

Elevated serum levels of $m i R-200 a, m i R-200 b, m i R-200 c$, and $m i R-141$ have been suggested as good biomarkers for diagnosis and prognosis in ovarian cancer [205,206,208], and serum levels of $m i R-429$ were associated with poor overall survival in NSCLC [169]. In addition, elevated levels of circulating miR-141 have been identified to show diagnostic potential in patients with upper urinary tract urothelial cancer [216], lung cancer [74], prostate cancer [12,217-220], breast cancer [207], and bladder cancer [374]. In breast and bladder cancer, this upregulation is also associated with prognosis. Furthermore, $m i R-200 c$ was found significantly elevated in the plasma of patients with colorectal cancer [210], gastric cancer [212,213], and breast cancer [207], and this upregulation was associated with poor prognosis. In colorectal cancer, it has also been identified as a metastasis predictive biomarker [211] as well as $m i R-141$ [221]. Similarly, miR-200c can be useful to predict prognosis in NSCLC [214] and in esophageal cancer. In the latest research, the serum level of miR-200c, as well as miR-200b, can be useful for predicting response to chemotherapy [215], and also has prognostic value in prostate cancer and predictive value in docetaxel chemotherapy outcomes [209].

\subsection{2. $\mathrm{miR}-210$}

miR-210 is strongly linked with the hypoxic pathway and angiogenesis through the targeting of EFNA3 [375,376], VEGF [377], and STAT3 [378]. miR-210 also acts upon cell cycle and apoptotic pathways by targeting E2F3, MNT [379-381], FGFRL1 [382], BCL2 [383,384], and STAT3 [378]. Furthermore, miR-210 can inhibit DNA damage repair genes such as RAD52 [385] and oncogenes such as HOXA1 [386].

Circulating miR-210 levels have been shown to have diagnostic value in DLBCL [11], pancreatic cancer [136,141,142,222,226], bladder cancer [227,228], glioma [229], liver carcinoma [230], and renal carcinoma [223,224] and with the presence of metastasis in patients with breast cancer [225] and pancreatic cancer [226]. $m i R-210$ has been also correlated with sensitivity to treatment in breast cancer and with prognosis in patients with breast cancer [225], pancreatic cancer [226], bladder cancer [227], and liver carcinoma [230].

\subsection{3. $m i R-221 /-222$}

$m i R-221$ and its paralogue $m i R-222$ are known to target angiogenesis by direct interaction with KIT [387,388], PTEN [389], TIMP3, ADAM10, and ADAM17 [390] and by indirectly regulating endothelial nitric oxide synthase expression [387,391]. miR-221/-222 have also been described as regulators of cell proliferation via the targeting of SEMA3B [392], IRF2, SOCS3 [393], 
p27/CDKN1B [394,395], HECTD2, RAB1A [396], $\beta$-catenin/CTNNB1, TGFB1 [397], ADAM17, ITGB4, and STAT3 [398]. Other pathways regulated by $m i R-221 /-222$ include apoptosis and metastasis via PTEN [389], IRF2, SOCS3 [393], BBC3 [399], SEMA3B [392], HECTD2, RAB1A [396], ADAM17, ITGB4, STAT5A [398], and Ecm29/KIAA0368 [400]; in resistance to chemotherapy in some type of cancers through PTEN [389] and $\beta$-catenin/CTNNB1 [397] regulation.

Circulating miR-221/-222 levels have been identified as diagnostic markers in prostate cancer [96], colorectal carcinoma [87,231], NK/T-cell lymphoma [104], liver carcinoma [111], larynx cancer [233], glioma [234], and melanoma [235]. They also have prognostic value in glioma [234], melanoma [235], prostate cancer [96], and renal carcinoma [236].

\subsection{4. $m i R-375$}

$m i R-375$ is a tumor suppressor miRNA that has been described in different kind of cancers, where it targets genes related to proliferation and apoptosis (JAK2, PDK1, 14-3-3ろ, IGF1R, KLF4, KLF5, survivin, ERBB2, PIK3CA, MTDH, YAP1, CIP2A / KIAA1524, MTDH, and BCL2) [401-414] as well as metastasis (IGF1R, CLDN1, CIP2A / KIAA1524, and BCL2) [404,412,414,415] and mediates resistance to therapy (IGF1R, TP53, and PHLPP1) [416-418]. Furthermore, miR-375 is involved in epithelial to mesenchymal transition in breast cancer [419] and targets ATG7 inhibiting autophagy and impairing the viability of cells under hypoxic conditions in liver cancer [420].

Circulating miR-375 has been identified as a diagnostic biomarker in oesophageal carcinoma [83,153], liver cancer [242], colorectal cancer [243], and lung cancer [421]. Additionally, in prostate cancer [218,239,240], lung cancer [238], and oesophageal carcinoma [241], miR-375 has been shown to have prognostic value.

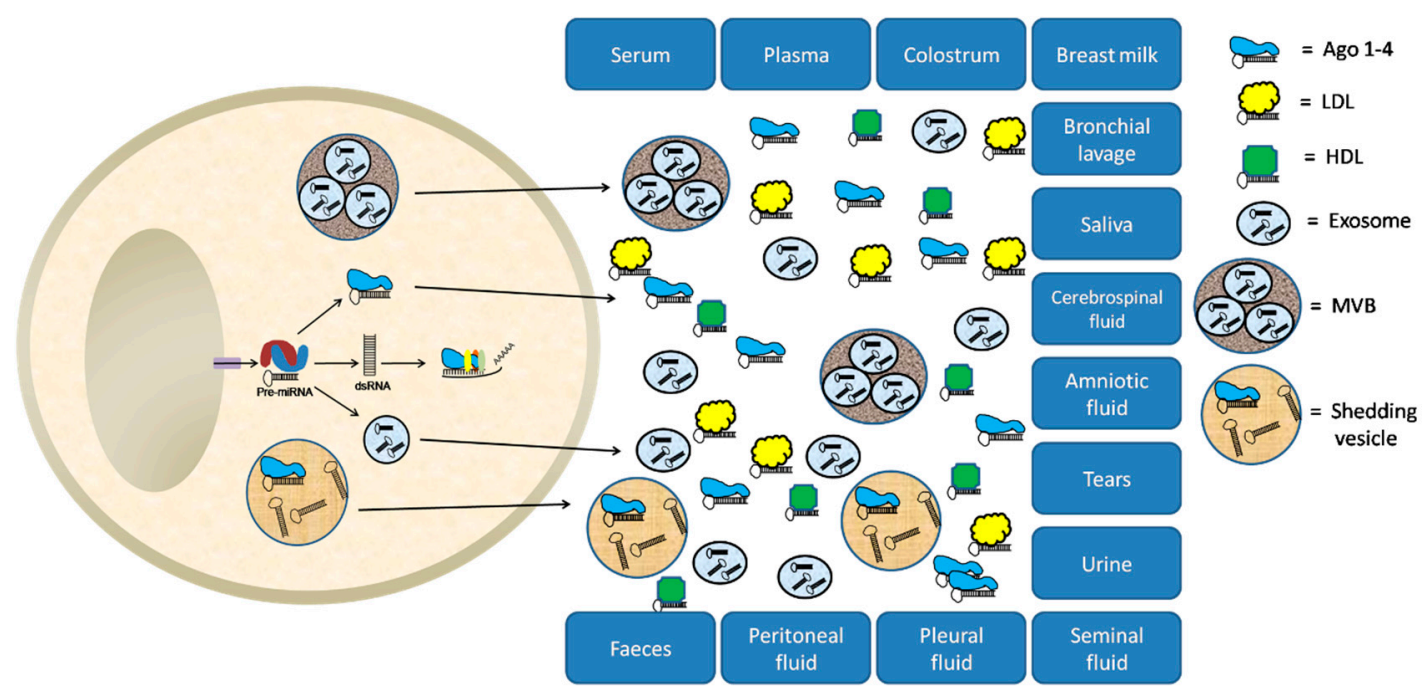

Figure 3. Origin of extracellular RNA. Several hypotheses have been proposed to explain the presence of miRNA in biological fluids, including the passive release of miRNA from broken cells and tissues and the active secretion from cells in microvesicles or conjugated to RNA-binding proteins. Cell-free miRNA can be detected in different body fluids including plasma, serum, saliva, tears, urine, amniotic fluid, colostrum, breast milk, bronchial lavage, cerebrospinal fluid, peritoneal fluid, pleural fluid, and seminal fluid and also in feces. Ago 1-4: Argonaute proteins 1-4; LDL: Low-density lipoprotein; HDL: High-density lipoprotein; MVB: Multivesicular body.

\section{Extracellular miRNAs in Other Biological Fluids}

In addition to blood, other biological fluids such as urine, saliva, cerebrospinal fluid, vitreous humor of the eye, breast milk, seminal fluid, and tears have been studied as potential sources of miRNA biomarkers [422,423] (Figure 3). The majority of these studies concern tumor types associated with 
the source of the biological fluids. For example, saliva has been studied in head and neck squamous cell carcinoma [183,424-427], tumors of the parotid gland [183,424,428], esophageal cancer [154], and pancreatic cancer [142,429]. Urine is another well studied source of cfmiRNAs associated with cancer in particular urological cancers including prostate and bladder cancer (reviewed in [430]). In addition, several studies have looked at the potential of urine for miRNA biomarkers in ovarian, breast, and liver cancer [126,431,432]. miRNAs in cerebrospinal fluid have been described as potential biomarkers for the diagnosis and monitoring of disease in brain tumors such as glioblastoma but also in CNS lymphomas and in brain metastases of non-neuronal origin [73,433-436]. In a similar vein, miRNAs, in the vitreous humor of the eye, have been identified in ocular cancers including vitreoretinal lymphoma or uveal melanoma $[437,438]$. It also has been suggested that the miRNA profile of breast milk could be a more sensitive biomarker for breast cancer than blood-associated miRNAs [439] and that seminal fluid-associated miRNAs can serve as biomarkers of prostate cancer [440].

\section{Discussion}

\section{Challenges in Studying cfmiRNA}

A major obstacle to the translation of cfmiRNAs from laboratory studies into the clinic is the lack of consistent and robust results with many apparently contradictory reports in the literature. A likely reason for this lack of reproducibility is that there are very few multi-center studies, and cohorts are often insufficiently powered. Another confounding factor is the fact that there is a high degree of inter-individual variability in the levels of cfmiRNAs, even when focusing only on healthy populations [441]. Moreover, there is a technical source of variation between studies, such as the starting material used for the experiments (e.g., the purification of cells, the cell types, the control populations used, the RNA extraction method, etc.), the technological platforms (e.g., microarray, qRT-PCR vs. next generation sequencing (NGS) etc.), and the differing statistical methodologies used.

The blood collection and processing represent critical points of variability in cfmiRNA studies. In the first instance, miRNA contamination can occur at the venopuncture site itself [442]. After extraction, the elapsed time between blood collection and processing should be minimized to prevent lysis and cellular contamination, which can be a major source of variability between samples [443-446]. In addition, the choice of anti-coagulant used in plasma collection can influence downstream detection technologies, such as qRT-PCR and heparin-coated tubes, should be avoided [447]. Another major source of difference in cfmiRNA profiles comes from the choice of whether to use serum or plasma, and whether to purify exosomes or use whole serum/plasma [448-451].

The choice of RNA purification procedure can also critically affect the results of cfmiRNA studies and should be considered carefully in terms of experimental design. For example, small RNA molecules with low GC content are known to be selectively lost during Trizol-based extraction (the most popular method) when present in low concentrations, such as in biological fluids, and thus should be avoided if possible; specific commercially available kits should be used instead [452]. Many researchers use non-human miRNAs (e.g., C. elegans sequences) as spike-in controls to control for variability between the miRNA extraction efficiency between samples [12]. Another important issue is that it is almost impossible to accurately quantify RNA in samples from biological fluids due to the low quantities of RNA present and the high levels of contaminating salts and protein that can interfere with spectrophotometric measurement. Therefore, studies often use fixed volumes of plasma to standardize, even if it is evident that they may contain different amounts of RNA [453].

There are many different methods available to measure cfmiRNAs, including qRT-PCR (LNA-based, Taqman or other proprietary technologies), digital PCR (dPCR), microarrays, and next generation sequencing (NGS) techniques. The choice of platform depends largely on the experimental design required (Figure 4). Importantly, it should be borne in mind that the choice of technique can massively influence measurements; indeed, several studies show a lack of concordance between platforms when using the same sample source [454,455]. 


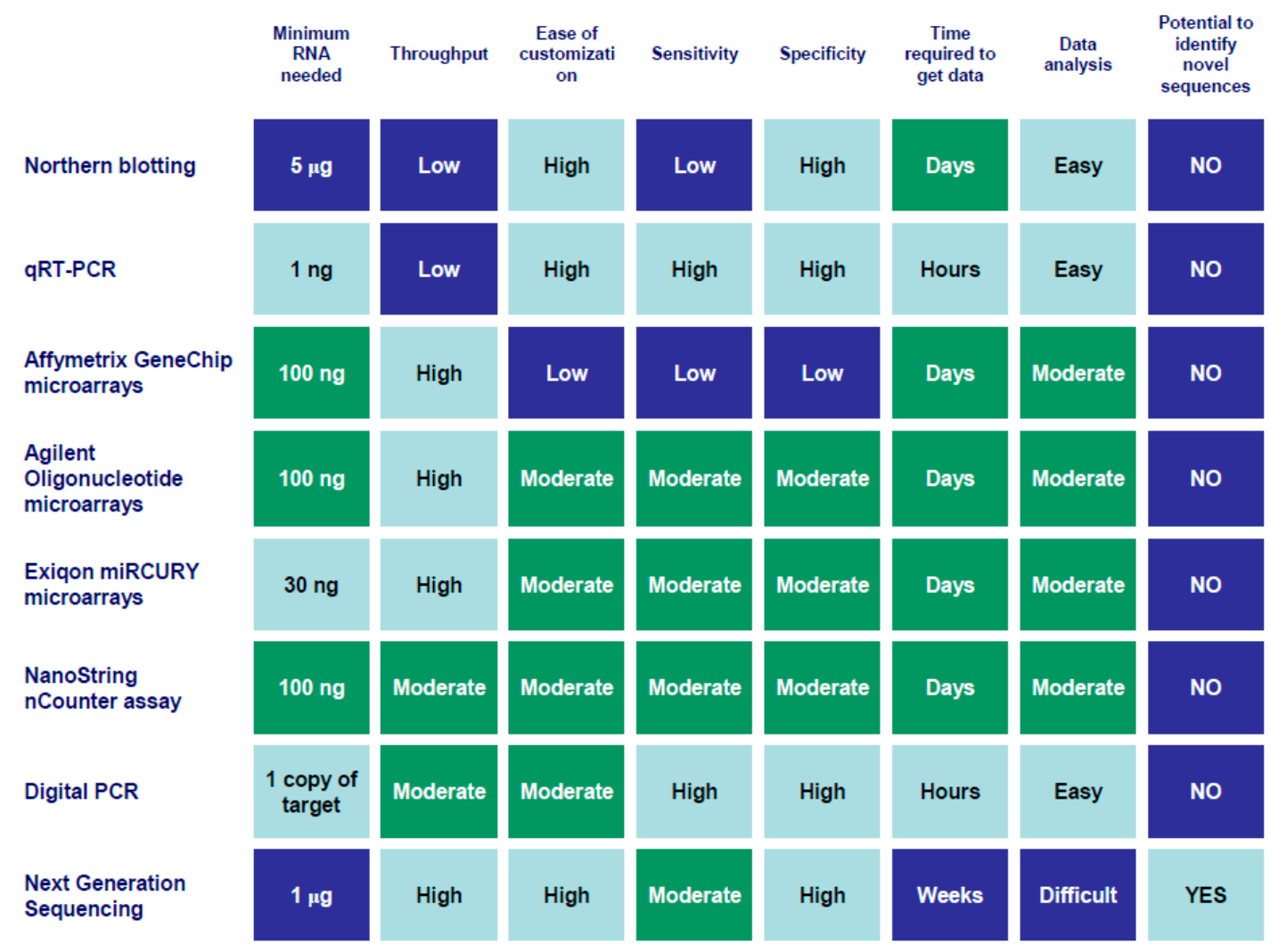

Figure 4. Comparison of methods commonly used to study extracellular RNA. Color code indicates the relative feasibility of that particular technique based on a given feature, from light blue (more feasible), through turquoise, to dark blue (less feasible). Data analysis: Easy (feasible in any molecular biology lab), Moderate (various software platforms available), Difficult (requires advanced computational infrastructure).

Another challenging issue in cfmiRNA studies is the lack of consensus about a suitable endogenous reference to use in biological fluids, as the small nucleolar RNAs (snoRNAs) generally used as reference genes in miRNA cell-based studies is not present in biological fluids due to degradation [456,457]. As an alternative, individual miRNAs themselves are frequently used $[11,12,458]$. However, it has been shown that the expression levels of the most commonly used housekeeping miRNAs in cfmiRNA studies vary significantly between samples depending upon the pathology that is being studied $[77,459]$. Therefore, miRNAs to be used as reference genes have to be chosen with care, determining empirically for each experiment which miRNAs are more stable (using geNorm and/or NormFinder algorithms), an approach taken by some studies $[458,459]$ but not always possible when sample volumes are limited. Alternatively, a more economical option is to include at least two (preferably three) miRNAs as reference controls for cfmiRNAs studies.

\section{Conclusions}

It is clear that there is a great deal of interest in liquid biopsies, and in cfmiRNA in particular, as a viable alternative to tissue-based sampling in the clinic. Such an approach would bring a fundamental change to cancer patient management by allowing repeated sampling for treatment response monitoring, an assessment of tumor heterogeneity, and even cancer screening programs. cfmiRNAs are particularly attractive candidates for non-invasive cancer biomarkers due to their surprising degree of stability in biological fluids; as we have outlined above, there is now a wealth of literature to suggest that this class of molecules holds great clinical promise. The caveat is that, as a very recently discovered field, there appears to be little agreement between seemingly identical studies, 
presumably due to many different factors outlined above between studies. In others words, there is a clear need of setting standardized approaches to be put into practicein future cfmiRNA biomarker studies if these molecules are to ever make their way into routine clinical practice.

Acknowledgments: We apologize to the authors of the many studies that were not included in this review because of space limitations. Charles H. Lawrie and his research is supported by grants from the Ikerbasque Foundation for Science, the Starmer-Smith Memorial Fund, the Ministerio de Economía y Competitividad of the Spanish Central Government and FEDER funds (PI12/00663, PIE13/00048, DTS14/00109, PI15/00275), the Consejerías de IndustriaComercio y Sanidad of the Basque Government, the Asociación Española Contra el Cancer (AECC), and the DiputaciónForal de Guipuzcoa (DFG). Marta Fernández-Mercado acknowledges support from AECC and DFG. Ibai Goicoechea also acknowledges support from AECC. Maria M. Caffarel acknowledges support from the Ikerbasque Foundation for Science and the Ministerio de Economía y Competitividad of Spanish Central Government. Erika Larrea also acknowledges support from the Ministerio de Economía y Competitividad of the Spanish Central Government.

Author Contributions: Erika Larrea and Carla Sole wrote most part of the manuscript, including literature update and critically reviewed and approved the final version of the manuscript. Lorea Manterola, María Armesto, María Arestin, María M. Caffarel, Angela M. Araujo and María Araiz wrote part of the manuscript and critically reviewed and approved the final version of the manuscript. Ibai Goicoechea wrote part of the manuscript, drew a figure and critically reviewed and approved the final version of the manuscript. Marta Fernandez-Mercado designed structure and contents of the manuscript, wrote part of the manuscript, drew figures and critically reviewed and approved the final version of the manuscript; and Charles H. Lawrie designed structure and contents of the manuscript, wrote part of the manuscript and critically reviewed and approved the final version of the manuscript.

Conflicts of Interest: The authors declare no conflict of interest.

\section{References}

1. World Health Organization. Available online: http://www.who.int/mediacentre/factsheets/fs297/en/ (accessed on 10 January 2016).

2. Pathak, A.K.; Bhutani, M.; Kumar, S.; Mohan, A.; Guleria, R. Circulating cell-free DNA in plasma/serum of lung cancer patients as a potential screening and prognostic tool. Clin. Chem. 2006, 52, 1833-1842. [PubMed]

3. Mandel, P.; Metais, P. Les acides nucléiques du plasma sanguin chez l'homme. C. R. Acad. Sci. Paris 1948, 142, 241-243.

4. Tan, E.M.; Schur, P.H.; Carr, R.I.; Kunkel, H.G. Deoxybonucleic acid (DNA) and antibodies to DNA in the serum of patients with systemic lupus erythematosus. J. Clin. Investig. 1966, 45, 1732-1740. [CrossRef] [PubMed]

5. Ayala, W.; Moore, L.V.; Hess, E.L. The purple color reaction given by diphenylamine reagent. I. With normal and rheumatic fever sera. J. Clin. Investig. 1951, 30, 781-785. [CrossRef] [PubMed]

6. Leon, S.A.; Shapiro, B.; Sklaroff, D.M.; Yaros, M.J. Free DNA in the serum of cancer patients and the effect of therapy. Cancer Res. 1977, 37, 646-650. [PubMed]

7. Vasioukhin, V.; Anker, P.; Maurice, P.; Lyautey, J.; Lederrey, C.; Stroun, M. Point mutations of the N-ras gene in the blood plasma DNA of patients with myelodysplastic syndrome or acute myelogenous leukaemia. Br. J. Haematol. 1994, 86, 774-779. [CrossRef] [PubMed]

8. Sorenson, G.D.; Pribish, D.M.; Valone, F.H.; Memoli, V.A.; Bzik, D.J.; Yao, S.L. Soluble normal and mutated DNA sequences from single-copy genes in human blood. Cancer Epidemiol. Biomark. Prev. 1994, 3, 67-71.

9. Lo, K.W.; Lo, Y.M.; Leung, S.F.; Tsang, Y.S.; Chan, L.Y.; Johnson, P.J.; Hjelm, N.M.; Lee, J.C.; Huang, D.P. Analysis of cell-free Epstein-Barr virus associated RNA in the plasma of patients with nasopharyngeal carcinoma. Clin. Chem. 1999, 45, 1292-1294. [PubMed]

10. Lawrie, C.H. MicroRNA expression in lymphoma. Expert Opin. Biol. Ther. 2007, 7, 1363-1374. [CrossRef] [PubMed]

11. Lawrie, C.H.; Gal, S.; Dunlop, H.M.; Pushkaran, B.; Liggins, A.P.; Pulford, K.; Banham, A.H.; Pezzella, F.; Boultwood, J.; Wainscoat, J.S.; et al. Detection of elevated levels of tumour-associated microRNAs in serum of patients with diffuse large B-cell lymphoma. Br. J. Haematol. 2008, 141, 672-675. [CrossRef] [PubMed]

12. Mitchell, P.S.; Parkin, R.K.; Kroh, E.M.; Fritz, B.R.; Wyman, S.K.; Pogosova-Agadjanyan, E.L.; Peterson, A.; Noteboom, J.; O’Briant, K.C.; Allen, A.; et al. Circulating microRNAs as stable blood-based markers for cancer detection. Proc. Natl. Acad. Sci. USA 2008, 105, 10513-10518. [CrossRef] [PubMed] 
13. Lee, R.C.; Ambros, V. An extensive class of small RNAs in Caenorhabditis elegans. Science 2001, $294,862-864$. [CrossRef] [PubMed]

14. Griffiths-Jones, S.; Grocock, R.J.; van Dongen, S.; Bateman, A.; Enright, A.J. miRBase: MicroRNA sequences, targets and gene nomenclature. Nucleic Acids Res. 2006, 34, D140-D144. [CrossRef] [PubMed]

15. Friedman, R.C.; Farh, K.K.; Burge, C.B.; Bartel, D.P. Most mammalian mRNAs are conserved targets of microRNAs. Genome Res. 2009, 19, 92-105. [CrossRef] [PubMed]

16. Kim, V.N. MicroRNA biogenesis: Coordinated cropping and dicing. Nat. Rev. Mol. Cell Biol. 2005, 6, 376-385. [CrossRef] [PubMed]

17. Hanahan, D.; Weinberg, R.A. The hallmarks of cancer. Cell 2000, 100, 57-70. [CrossRef]

18. Hanahan, D.; Weinberg, R.A. Hallmarks of cancer: The next generation. Cell 2011, 144, 646-674. [CrossRef] [PubMed]

19. Turchinovich, A.; Weiz, L.; Burwinkel, B. Extracellular miRNAs: The mystery of their origin and function. Trends Biochem. Sci. 2012, 37, 460-465. [CrossRef] [PubMed]

20. Cortez, M.A.; Bueso-Ramos, C.; Ferdin, J.; Lopez-Berestein, G.; Sood, A.K.; Calin, G.A. MicroRNAs in body fluids-The mix of hormones and biomarkers. Nat. Rev. Clin. Oncol. 2011, 8, 467-477. [CrossRef] [PubMed]

21. Witwer, K.W. Circulating microRNA biomarker studies: Pitfalls and potential solutions. Clin. Chem. 2015, 61, 56-63. [CrossRef] [PubMed]

22. Turchinovich, A.; Weiz, L.; Langheinz, A.; Burwinkel, B. Characterization of extracellular circulating microRNA. Nucleic Acids Res. 2011, 39, 7223-7233. [CrossRef] [PubMed]

23. Laterza, O.F.; Lim, L.; Garrett-Engele, P.W.; Vlasakova, K.; Muniappa, N.; Tanaka, W.K.; Johnson, J.M.; Sina, J.F.; Fare, T.L.; Sistare, F.D.; et al. Plasma microRNAs as sensitive and specific biomarkers of tissue injury. Clin. Chem. 2009, 55, 1977-1983. [CrossRef] [PubMed]

24. Corsten, M.F.; Dennert, R.; Jochems, S.; Kuznetsova, T.; Devaux, Y.; Hofstra, L.; Wagner, D.R.; Staessen, J.A.; Heymans, S.; Schroen, B. Circulating microRNA-208b and microRNA-499 reflect myocardial damage in cardiovascular disease. Circ. Cardiovasc. Genet. 2010, 3, 499-506. [CrossRef] [PubMed]

25. Gholamin, S.; Pasdar, A.; Khorrami, M.S.; Mirzaei, H.; Mirzaei, H.R.; Salehi, R.; Ferns, G.A.; Ghayour-Mobarhan, M.; Avan, A. The potential for circulating microRNAs in the diagnosis of myocardial infarction: A novel approach to disease diagnosis and treatment. Curr. Pharm. Des. 2016, 22, 397-403. [CrossRef] [PubMed]

26. Sayed, A.S.; Xia, K.; Yang, T.L.; Peng, J. Circulating microRNAs: A potential role in diagnosis and prognosis of acute myocardial infarction. Dis. Markers 2013, 35, 561-566. [CrossRef] [PubMed]

27. Anker, P.; Mulcahy, H.; Stroun, M. Circulating nucleic acids in plasma and serum as a noninvasive investigation for cancer: Time for large-scale clinical studies? Int. J. Cancer 2003, 103, 149-152. [CrossRef] [PubMed]

28. Hunter, M.P.; Ismail, N.; Zhang, X.; Aguda, B.D.; Lee, E.J.; Yu, L.; Xiao, T.; Schafer, J.; Lee, M.L.; Schmittgen, T.D.; et al. Detection of microRNA expression in human peripheral blood microvesicles. PLoS ONE 2008, 3, e3694. [CrossRef] [PubMed]

29. Ismail, N.; Wang, Y.; Dakhlallah, D.; Moldovan, L.; Agarwal, K.; Batte, K.; Shah, P.; Wisler, J.; Eubank, T.D.; Tridandapani, S.; et al. Macrophage microvesicles induce macrophage differentiation and miR-223 transfer. Blood 2013, 121, 984-995. [CrossRef] [PubMed]

30. Valadi, H.; Ekstrom, K.; Bossios, A.; Sjostrand, M.; Lee, J.J.; Lotvall, J.O. Exosome-mediated transfer of mRNAs and microRNAs is a novel mechanism of genetic exchange between cells. Nat. Cell Biol. 2007, 9, 654-659. [CrossRef] [PubMed]

31. Wang, K.; Zhang, S.; Weber, J.; Baxter, D.; Galas, D.J. Export of microRNAs and microRNA-protective protein by mammalian cells. Nucleic Acids Res. 2010, 38, 7248-7259. [CrossRef] [PubMed]

32. Vickers, K.C.; Palmisano, B.T.; Shoucri, B.M.; Shamburek, R.D.; Remaley, A.T. MicroRNAs are transported in plasma and delivered to recipient cells by high-density lipoproteins. Nat. Cell Biol. 2011, 13, 423-433. [CrossRef] [PubMed]

33. Arroyo, J.D.; Chevillet, J.R.; Kroh, E.M.; Ruf, I.K.; Pritchard, C.C.; Gibson, D.F.; Mitchell, P.S.; Bennett, C.F.; Pogosova-Agadjanyan, E.L.; Stirewalt, D.L.; et al. Argonaute2 complexes carry a population of circulating microRNAs independent of vesicles in human plasma. Proc. Natl. Acad. Sci. USA 2011, 108, 5003-5008. [CrossRef] [PubMed] 
34. Gallo, A.; Tandon, M.; Alevizos, I.; Illei, G.G. The majority of microRNAs detectable in serum and saliva is concentrated in exosomes. PLoS ONE 2012, 7, e30679. [CrossRef] [PubMed]

35. Mittelbrunn, M.; Gutierrez-Vazquez, C.; Villarroya-Beltri, C.; Gonzalez, S.; Sanchez-Cabo, F.; Gonzalez, M.A.; Bernad, A.; Sanchez-Madrid, F. Unidirectional transfer of microRNA-loaded exosomes from T cells to antigen-presenting cells. Nat. Commun. 2011, 2, 282. [CrossRef] [PubMed]

36. Baulcombe, D.C. RNA as a target and an initiator of post-transcriptional gene silencing in transgenic plants. Plant Mol. Biol. 1996, 32, 79-88. [CrossRef] [PubMed]

37. Turchinovich, A.; Samatov, T.R.; Tonevitsky, A.G.; Burwinkel, B. Circulating miRNAs: Cell-cell communication function? Front. Genet. 2013, 4, 119. [CrossRef] [PubMed]

38. Thery, C. Exosomes: Secreted vesicles and intercellular communications. F1000 Biol. Rep. 2011, 3, 15. [CrossRef] [PubMed]

39. Skog, J.; Wurdinger, T.; van Rijn, S.; Meijer, D.H.; Gainche, L.; Sena-Esteves, M.; Curry, W.T., Jr.; Carter, B.S.; Krichevsky, A.M.; Breakefield, X.O. Glioblastoma microvesicles transport RNA and proteins that promote tumour growth and provide diagnostic biomarkers. Nat. Cell Biol. 2008, 10, 1470-1476. [CrossRef] [PubMed]

40. Pegtel, D.M.; Cosmopoulos, K.; Thorley-Lawson, D.A.; van Eijndhoven, M.A.; Hopmans, E.S.; Lindenberg, J.L.; de Gruijl, T.D.; Wurdinger, T.; Middeldorp, J.M. Functional delivery of viral miRNAs via exosomes. Proc. Natl. Acad. Sci. USA 2010, 107, 6328-6333. [CrossRef] [PubMed]

41. Yuan, A.; Farber, E.L.; Rapoport, A.L.; Tejada, D.; Deniskin, R.; Akhmedov, N.B.; Farber, D.B. Transfer of microRNAs by embryonic stem cell microvesicles. PLoS ONE 2009, 4, e4722. [CrossRef] [PubMed]

42. Mao, L.; Li, J.; Chen, W.X.; Cai, Y.Q.; Yu, D.D.; Zhong, S.L.; Zhao, J.H.; Zhou, J.W.; Tang, J.H. Exosomes decrease sensitivity of breast cancer cells to adriamycin by delivering microRNAs. Tumour Biol. 2015. [CrossRef] [PubMed]

43. De Souza, P.S.; Faccion, R.S.; Bernardo, P.S.; Maia, R.C. Membrane microparticles: Shedding new light into cancer cell communication. Cancer Res. Clin. Oncol. 2015. [CrossRef] [PubMed]

44. Maushagen, R.; Pries, R.; Wollenberg, B. Chemotherapy with paclitaxel leads to microRNA release. HNO 2015, 63, 792-796. [CrossRef] [PubMed]

45. Hannafon, B.N.; Carpenter, K.J.; Berry, W.L.; Janknecht, R.; Dooley, W.C.; Ding, W.Q. Exosome-mediated microRNA signaling from breast cancer cells is altered by the anti-angiogenesis agent docosahexaenoic acid (DHA). Mol. Cancer 2015, 14, 133. [CrossRef] [PubMed]

46. Gai, C.; Carpanetto, A.; Deregibus, M.C.; Camussi, G. Extracellular vesicle-mediated modulation of angiogenesis. Histol. Histopathol. 2015, 34, 11708.

47. Lu, J.; Getz, G.; Miska, E.A.; Alvarez-Saavedra, E.; Lamb, J.; Peck, D.; Sweet-Cordero, A.; Ebert, B.L.; Mak, R.H.; Ferrando, A.A.; et al. MicroRNA expression profiles classify human cancers. Nature 2005, 435, 834-838. [CrossRef] [PubMed]

48. Lawrie, C.H.; Soneji, S.; Marafioti, T.; Cooper, C.D.; Palazzo, S.; Paterson, J.C.; Cattan, H.; Enver, T.; Mager, R.; Boultwood, J.; et al. MicroRNA expression distinguishes between germinal center B cell-like and activated B cell-like subtypes of diffuse large B cell lymphoma. Int. J. Cancer 2007, 121, 1156-1161. [CrossRef] [PubMed]

49. Mo, M.H.; Chen, L.; Fu, Y.; Wang, W.; Fu, S.W. Cell-free Circulating miRNA Biomarkers in Cancer. J. Cancer 2012, 3, 432-448. [CrossRef] [PubMed]

50. Chen, X.; Ba, Y.; Ma, L.; Cai, X.; Yin, Y.; Wang, K.; Guo, J.; Zhang, Y.; Chen, J.; Guo, X.; et al. Characterization of microRNAs in serum: A novel class of biomarkers for diagnosis of cancer and other diseases. Cell Res. 2008, 18, 997-1006. [CrossRef] [PubMed]

51. Kosaka, N.; Iguchi, H.; Ochiya, T. Circulating microRNA in body fluid: A new potential biomarker for cancer diagnosis and prognosis. Cancer Sci. 2010, 101, 2087-2092. [CrossRef] [PubMed]

52. Kelly, B.D.; Miller, N.; Sweeney, K.J.; Durkan, G.C.; Rogers, E.; Walsh, K.; Kerin, M.J. A Circulating MicroRNA Signature as a Biomarker for Prostate Cancer in a High Risk Group. J. Clin. Med. 2015, 4, 1369-1379. [CrossRef] [PubMed]

53. Ogata-Kawata, H.; Izumiya, M.; Kurioka, D.; Honma, Y.; Yamada, Y.; Furuta, K.; Gunji, T.; Ohta, H.; Okamoto, H.; Sonoda, H.; et al. Circulating exosomal microRNAs as biomarkers of colon cancer. PLoS ONE 2014, 9, e92921. 
54. Ghanbari, R.; Mosakhani, N.; Sarhadi, V.K.; Armengol, G.; Nouraee, N.; Mohammadkhani, A.; Khorrami, S.; Arefian, E.; Paryan, M.; Malekzadeh, R.; et al. Simultaneous Underexpression of let-7a-5p and let-7f-5p microRNAs in Plasma and Stool Samples from Early Stage Colorectal Carcinoma. Biomark. Cancer 2015, 7, 39-48. [PubMed]

55. Zuo, Z.; Calin, G.A.; de Paula, H.M.; Medeiros, L.J.; Fernandez, M.H.; Shimizu, M.; Garcia-Manero, G.; Bueso-Ramos, C.E. Circulating microRNAs let-7a and miR-16 predict progression-free survival and overall survival in patients with myelodysplastic syndrome. Blood 2011, 118, 413-415. [CrossRef] [PubMed]

56. Tsujiura, M.; Ichikawa, D.; Komatsu, S.; Shiozaki, A.; Takeshita, H.; Kosuga, T.; Konishi, H.; Morimura, R.; Deguchi, K.; Fujiwara, H.; et al. Circulating microRNAs in plasma of patients with gastric cancers. Br. J. Cancer 2010, 102, 1174-1179. [CrossRef] [PubMed]

57. Heegaard, N.H.; Schetter, A.J.; Welsh, J.A.; Yoneda, M.; Bowman, E.D.; Harris, C.C. Circulating micro-RNA expression profiles in early stage nonsmall cell lung cancer. Int. J. Cancer 2012, 130, 1378-1386. [CrossRef] [PubMed]

58. Hung, C.H.; Hu, T.H.; Lu, S.N.; Kuo, F.Y.; Chen, C.H.; Wang, J.H.; Huang, C.M.; Lee, C.M.; Lin, C.Y.; Yen, Y.H.; et al. Circulating microRNAs as biomarkers for diagnosis of early hepatocellular carcinoma associated with hepatitis B virus. Int. J. Cancer 2016, 138, 714-720. [CrossRef] [PubMed]

59. Chung, Y.W.; Bae, H.S.; Song, J.Y.; Lee, J.K.; Lee, N.W.; Kim, T.; Lee, K.W. Detection of microRNA as novel biomarkers of epithelial ovarian cancer from the serum of ovarian cancer patients. Int. J. Gynecol. Cancer 2013, 23, 673-679. [CrossRef] [PubMed]

60. Dou, H.; Wang, Y.; Su, G.; Zhao, S. Decreased plasma let-7c and miR-152 as noninvasive biomarker for non-small-cell lung cancer. Int. J. Clin. Exp. Med. 2015, 8, 9291-9298. [PubMed]

61. Li, X.X.; Gao, S.Y.; Wang, P.Y.; Zhou, X.; Li, Y.J.; Yu, Y.; Yan, Y.F.; Zhang, H.H.; Lv, C.J.; Zhou, H.H.; et al. Reduced expression levels of let-7c in human breast cancer patients. Oncol. Lett. 2015, 9, 1207-1212. [CrossRef] [PubMed]

62. Liu, W.J.; Xu, Q.; Sun, L.P.; Dong, Q.G.; He, C.Y.; Yuan, Y. Expression of serum let-7c, let-7i, and let-7f microRNA with its target gene, pepsinogen $C$, in gastric cancer and precancerous disease. Tumour Biol. 2015, 36, 3337-3343. [CrossRef] [PubMed]

63. Ali, S.; Almhanna, K.; Chen, W.; Philip, P.A.; Sarkar, F.H. Differentially expressed miRNAs in the plasma may provide a molecular signature for aggressive pancreatic cancer. Am. J. Transl. Res. 2010, 3, 28-47. [PubMed]

64. Kubiczkova, L.; Kryukov, F.; Slaby, O.; Dementyeva, E.; Jarkovsky, J.; Nekvindova, J.; Radova, L.; Greslikova, H.; Kuglik, P.; Vetesnikova, E.; et al. Circulating serum microRNAs as novel diagnostic and prognostic biomarkers for multiple myeloma and monoclonal gammopathy of undetermined significance. Haematologica 2014, 99, 511-518. [CrossRef] [PubMed]

65. Yu, S.; Liu, Y.; Wang, J.; Guo, Z.; Zhang, Q.; Yu, F.; Zhang, Y.; Huang, K.; Li, Y.; Song, E.; et al. Circulating microRNA profiles as potential biomarkers for diagnosis of papillary thyroid carcinoma. J. Clin. Endocrinol. Metab. 2012, 97, 2084-2092. [CrossRef] [PubMed]

66. Zheng, H.; Zhang, L.; Zhao, Y.; Yang, D.; Song, F.; Wen, Y.; Hao, Q.; Hu, Z.; Zhang, W.; Chen, K. Plasma miRNAs as diagnostic and prognostic biomarkers for ovarian cancer. PLoS ONE 2013, 8, e77853. [CrossRef] [PubMed]

67. Silva, J.; Garcia, V.; Zaballos, A.; Provencio, M.; Lombardia, L.; Almonacid, L.; Garcia, J.M.; Dominguez, G.; Pena, C.; Diaz, R.; et al. Vesicle-related microRNAs in plasma of nonsmall cell lung cancer patients and correlation with survival. Eur. Respir. J. 2011, 37, 617-623. [CrossRef] [PubMed]

68. Ge, W.; Yu, D.C.; Li, Q.G.; Chen, X.; Zhang, C.Y.; Ding, Y.T. Expression of serum miR-16, let-7f, and miR-21 in patients with hepatocellular carcinoma and their clinical significances. Clin. Lab. 2014, 60, 427-434. [PubMed]

69. Huang, J.; Wu, J.; Li, Y.; Li, X.; Yang, T.; Yang, Q.; Jiang, Y. Deregulation of serum microRNA expression is associated with cigarette smoking and lung cancer. BioMed Res. Int. 2014, 2014, 364316. [CrossRef] [PubMed]

70. Langhe, R.; Norris, L.; Saadeh, F.A.; Blackshields, G.; Varley, R.; Harrison, A.; Gleeson, N.; Spillane, C.; Martin, C.; O'Donnell, D.M.; et al. A novel serum microRNA panel to discriminate benign from malignant ovarian disease. Cancer Lett. 2015, 356, 628-636. [CrossRef] [PubMed]

71. Anfossi, S.; Giordano, A.; Gao, H.; Cohen, E.N.; Tin, S.; Wu, Q.; Garza, R.J.; Debeb, B.G.; Alvarez, R.H.; Valero, V.; et al. High serum miR-19a levels are associated with inflammatory breast cancer and are predictive of favorable clinical outcome in patients with metastatic HER2 ${ }^{+}$inflammatory breast cancer. PLoS ONE 2014, 9, e83113. [CrossRef] [PubMed] 
72. Roth, C.; Rack, B.; Muller, V.; Janni, W.; Pantel, K.; Schwarzenbach, H. Circulating microRNAs as blood-based markers for patients with primary and metastatic breast cancer. Breast Cancer Res. 2010, 12, R90. [CrossRef] [PubMed]

73. Teplyuk, N.M.; Mollenhauer, B.; Gabriely, G.; Giese, A.; Kim, E.; Smolsky, M.; Kim, R.Y.; Saria, M.G.; Pastorino, S.; Kesari, S.; et al. MicroRNAs in cerebrospinal fluid identify glioblastoma and metastatic brain cancers and reflect disease activity. Neuro Oncol. 2012, 14, 689-700. [CrossRef] [PubMed]

74. Roth, C.; Kasimir-Bauer, S.; Pantel, K.; Schwarzenbach, H. Screening for circulating nucleic acids and caspase activity in the peripheral blood as potential diagnostic tools in lung cancer. Mol. Oncol. 2011, 5, 281-291. [CrossRef] [PubMed]

75. Xu, H.; Yao, Y.; Meng, F.; Qian, X.; Jiang, X.; Li, X.; Gao, Z.; Gao, L. Predictive Value of Serum miR-10b, miR-29c, and miR-205 as Promising Biomarkers in Esophageal Squamous Cell Carcinoma Screening. Medicine (Baltimore) 2015, 94, e1558. [CrossRef] [PubMed]

76. Maclellan, S.A.; Lawson, J.; Baik, J.; Guillaud, M.; Poh, C.F.; Garnis, C. Differential expression of miRNAs in the serum of patients with high-risk oral lesions. Cancer Med. 2012, 1, 268-274. [CrossRef] [PubMed]

77. Lodes, M.J.; Caraballo, M.; Suciu, D.; Munro, S.; Kumar, A.; Anderson, B. Detection of cancer with serum miRNAs on an oligonucleotide microarray. PLoS ONE 2009, 4, e6229. [CrossRef] [PubMed]

78. Mahn, R.; Heukamp, L.C.; Rogenhofer, S.; von Ruecker, A.; Muller, S.C.; Ellinger, J. Circulating microRNAs (miRNA) in serum of patients with prostate cancer. Urology 2011, 77, 1265.e9-1265.e16. [CrossRef] [PubMed]

79. Hu, Z.; Dong, J.; Wang, L.E.; Ma, H.; Liu, J.; Zhao, Y.; Tang, J.; Chen, X.; Dai, J.; Wei, Q.; et al. Serum microRNA profiling and breast cancer risk: The use of miR-484/191 as endogenous controls. Carcinogenesis 2012, 33, 828-834. [CrossRef] [PubMed]

80. Li, H.; Zhang, K.; Liu, L.H.; Ouyang, Y.; Guo, H.B.; Zhang, H.; Bu, J.; Xiao, T. MicroRNA screening identifies circulating microRNAs as potential biomarkers for osteosarcoma. Oncol. Lett. 2015, 10, 1662-1668. [CrossRef] [PubMed]

81. Zhang, J.; Song, Y.; Zhang, C.; Zhi, X.; Fu, H.; Ma, Y.; Chen, Y.; Pan, F.; Wang, K.; Ni, J.; et al. Circulating MiR-16-5p and MiR-19b-3p as Two Novel Potential Biomarkers to Indicate Progression of Gastric Cancer. Theranostics 2015, 5, 733-745. [CrossRef]

82. Wang, H.; Wang, L.; Wu, Z.; Sun, R.; Jin, H.; Ma, J.; Liu, L.; Ling, R.; Yi, J.; Wang, L.; et al. Three dysregulated microRNAs in serum as novel biomarkers for gastric cancer screening. Med. Oncol. 2014, 31, 298. [CrossRef] [PubMed]

83. Li, B.X.; Yu, Q.; Shi, Z.L.; Li, P.; Fu, S. Circulating microRNAs in esophageal squamous cell carcinoma: Association with locoregional staging and survival. Int. J. Clin. Exp. Med. 2015, 8, 7241-7250.

84. Hirajima, S.; Komatsu, S.; Ichikawa, D.; Takeshita, H.; Konishi, H.; Shiozaki, A.; Morimura, R.; Tsujiura, M.; Nagata, H.; Kawaguchi, T.; et al. Clinical impact of circulating miR-18a in plasma of patients with oesophageal squamous cell carcinoma. Br. J. Cancer 2013, 108, 1822-1829. [CrossRef]

85. Tsujiura, M.; Komatsu, S.; Ichikawa, D.; Shiozaki, A.; Konishi, H.; Takeshita, H.; Moriumura, R.; Nagata, H.; Kawaguchi, T.; Hirajima, S.; et al. Circulating miR-18a in plasma contributes to cancer detection and monitoring in patients with gastric cancer. Gastric Cancer 2015, 18, 271-279. [CrossRef]

86. Kodahl, A.R.; Lyng, M.B.; Binder, H.; Cold, S.; Gravgaard, K.; Knoop, A.S.; Ditzel, H.J. Novel circulating microRNA signature as a potential non-invasive multi-marker test in ER-positive early-stage breast cancer: A case control study. Mol. Oncol. 2014, 8, 874-883. [CrossRef] [PubMed]

87. Yau, T.O.; Wu, C.W.; Dong, Y.; Tang, C.M.; Ng, S.S.; Chan, F.K.; Sung, J.J.; Yu, J. microRNA-221 and microRNA-18a identification in stool as potential biomarkers for the non-invasive diagnosis of colorectal carcinoma. Br. J. Cancer 2014, 111, 1765-1771. [CrossRef] [PubMed]

88. Pfeffer, S.R.; Grossmann, K.F.; Cassidy, P.B.; Yang, C.H.; Fan, M.; Kopelovich, L.; Leachman, S.A.; Pfeffer, L.M. Detection of Exosomal miRNAs in the Plasma of Melanoma Patients. J. Clin. Med. 2015, 4, 2012-2027. [CrossRef] [PubMed]

89. Li, Q.; Liu, M.; Ma, F.; Luo, Y.; Cai, R.; Wang, L.; Xu, N.; Xu, B. Circulating miR-19a and miR-205 in serum may predict the sensitivity of luminal A subtype of breast cancer patients to neoadjuvant chemotherapy with epirubicin plus paclitaxel. PLoS ONE 2014, 9, e104870. [CrossRef] [PubMed]

90. Sochor, M.; Basova, P.; Pesta, M.; Dusilkova, N.; Bartos, J.; Burda, P.; Pospisil, V.; Stopka, T. Oncogenic microRNAs: miR-155, miR-19a, miR-181b, and miR-24 enable monitoring of early breast cancer in serum. BMC Cancer 2014, 14, 448. [CrossRef] 
91. Feng, Y.; Liu, J.; Kang, Y.; He, Y.; Liang, B.; Yang, P.; Yu, Z. miR-19a acts as an oncogenic microRNA and is up-regulated in bladder cancer. J. Exp. Clin. Cancer Res. 2014, 33, 67. [CrossRef] [PubMed]

92. Matsumura, T.; Sugimachi, K.; Iinuma, H.; Takahashi, Y.; Kurashige, J.; Sawada, G.; Ueda, M.; Uchi, R.; Ueo, H.; Takano, Y.; et al. Exosomal microRNA in serum is a novel biomarker of recurrence in human colorectal cancer. Br. J. Cancer 2015, 113, 275-281. [CrossRef] [PubMed]

93. Hao, M.; Zang, M.; Wendlandt, E.; Xu, Y.; An, G.; Gong, D.; Li, F.; Qi, F.; Zhang, Y.; Yang, Y.; et al. Low serum miR-19a expression as a novel poor prognostic indicator in multiple myeloma. Int. J. Cancer 2015, 136, 1835-1844. [CrossRef]

94. Lin, Q.; Chen, T.; Lin, Q.; Lin, G.; Lin, J.; Chen, G.; Guo, L. Serum miR-19a expression correlates with worse prognosis of patients with non-small cell lung cancer. J. Surg. Oncol. 2013, 107, 767-771. [CrossRef] [PubMed]

95. Wu, C.; Cao, Y.; He, Z.; He, J.; Hu, C.; Duan, H.; Jiang, J. Serum levels of miR-19b and miR-146a as prognostic biomarkers for non-small cell lung cancer. Tohoku J. Exp. Med. 2014, 232, 85-95. [CrossRef] [PubMed]

96. Shen, J.; Hruby, G.W.; McKiernan, J.M.; Gurvich, I.; Lipsky, M.J.; Benson, M.C.; Santella, R.M. Dysregulation of circulating microRNAs and prediction of aggressive prostate cancer. Prostate 2012, 72, 1469-1477. [CrossRef] [PubMed]

97. Geng, Q.; Fan, T.; Zhang, B.; Wang, W.; Xu, Y.; Hu, H. Five microRNAs in plasma as novel biomarkers for screening of early-stage non-small cell lung cancer. Respir. Res. 2014, 15, 149. [CrossRef] [PubMed]

98. Yau, T.O.; Wu, C.W.; Tang, C.M.; Chen, Y.; Fang, J.; Dong, Y.; Liang, Q.; Ng, S.S.; Chan, F.K.; Sung, J.J.; et al. MicroRNA-20a in human faeces as a non-invasive biomarker for colorectal cancer. Oncotarget 2016, 7, 1559-1568. [PubMed]

99. He, F.C.; Meng, W.W.; Qu, Y.H.; Zhou, M.X.; He, J.; Lv, P.; Ming, L. Expression of circulating microRNA-20a and let-7a in esophageal squamous cell carcinoma. World J. Gastroenterol. 2015, 21, 4660-4665. [PubMed]

100. Conev, N.V.; Donev, I.S.; Konsoulova-Kirova, A.A.; Chervenkov, T.G.; Kashlov, J.K.; Ivanov, K.D. Serum expression levels of miR-17, miR-21, and miR-92 as potential biomarkers for recurrence after adjuvant chemotherapy in colon cancer patients. Biosci. Trends 2016, 9, 393-401. [CrossRef] [PubMed]

101. Ng, E.K.; Chong, W.W.; Jin, H.; Lam, E.K.; Shin, V.Y.; Yu, J.; Poon, T.C.; Ng, S.S.; Sung, J.J. Differential expression of microRNAs in plasma of patients with colorectal cancer: A potential marker for colorectal cancer screening. Gut 2009, 58, 1375-1381. [CrossRef] [PubMed]

102. Resnick, K.E.; Alder, H.; Hagan, J.P.; Richardson, D.L.; Croce, C.M.; Cohn, D.E. The detection of differentially expressed microRNAs from the serum of ovarian cancer patients using a novel real-time PCR platform. Gynecol. Oncol. 2009, 112, 55-59. [CrossRef] [PubMed]

103. Huang, Z.; Huang, D.; Ni, S.; Peng, Z.; Sheng, W.; Du, X. Plasma microRNAs are promising novel biomarkers for early detection of colorectal cancer. Int. J. Cancer 2010, 127, 118-126. [CrossRef] [PubMed]

104. Tanaka, M.; Oikawa, K.; Takanashi, M.; Kudo, M.; Ohyashiki, J.; Ohyashiki, K.; Kuroda, M. Down-regulation of miR-92 in human plasma is a novel marker for acute leukemia patients. PLoS ONE 2009, 4, e5532. [CrossRef] [PubMed]

105. Yuan, R.; Wang, G.; Zhi, Q.; Chen, H.; Han, Y.; Wang, B.; Kou, Z.; Hu, H.; Guo, Z.; Xue, X.; et al. Up-regulated circulating miR-106a by DNA methylation promised a potential diagnostic and prognostic marker for gastric cancer. Anticancer Agents Med. Chem. 2015. PMID:26179261.

106. Koga, Y.; Yamazaki, N.; Yamamoto, Y.; Yamamoto, S.; Saito, N.; Kakugawa, Y.; Otake, Y.; Matsumoto, M.; Matsumura, Y. Fecal miR-106a is a useful marker for colorectal cancer patients with false-negative results in immunochemical fecal occult blood test. Cancer Epidemiol. Biomark. Prev. 2013, 22, 1844-1852. [CrossRef] [PubMed]

107. Chen, W.Y.; Zhao, X.J.; Yu, Z.F.; Hu, F.L.; Liu, Y.P.; Cui, B.B.; Dong, X.S.; Zhao, Y.S. The potential of plasma miRNAs for diagnosis and risk estimation of colorectal cancer. Int. J. Clin. Exp. Pathol. 2015, 8, 7092-7101. [PubMed]

108. Li, J.; Liu, Y.; Wang, C.; Deng, T.; Liang, H.; Wang, Y.; Huang, D.; Fan, Q.; Wang, X.; Ning, T.; et al. Serum miRNA expression profile as a prognostic biomarker of stage II/III colorectal adenocarcinoma. Sci. Rep. 2015, 5, 12921. [CrossRef] [PubMed]

109. Zeng, Q.; Jin, C.; Chen, W.; Xia, F.; Wang, Q.; Fan, F.; Du, J.; Guo, Y.; Lin, C.; Yang, K.; et al. Downregulation of serum miR-17 and miR-106b levels in gastric cancer and benign gastric diseases. Chin. J. Cancer Res. 2014, 26, 711-716. [PubMed] 
110. Jiang, L.; Li, X.; Cheng, Q.; Zhang, B.H. Plasma microRNA might as a potential biomarker for hepatocellular carcinoma and chronic liver disease screening. Tumour Biol. 2015, 36, 7167-7174. [CrossRef] [PubMed]

111. Sohn, W.; Kim, J.; Kang, S.H.; Yang, S.R.; Cho, J.Y.; Cho, H.C.; Shim, S.G.; Paik, Y.H. Serum exosomal microRNAs as novel biomarkers for hepatocellular carcinoma. Exp. Mol. Med. 2015, 47, e184. [CrossRef] [PubMed]

112. Zheng, R.; Pan, L.; Gao, J.; Ye, X.; Chen, L.; Zhang, X.; Tang, W.; Zheng, W. Prognostic value of miR-106b expression in breast cancer patients. J. Surg. Res. 2015, 195, 158-165. [CrossRef] [PubMed]

113. Zhang, R.; Wang, W.; Li, F.; Zhang, H.; Liu, J. MicroRNA-106b 25 expressions in tumor tissues and plasma of patients with gastric cancers. Med. Oncol. 2014, 31, 243. [CrossRef] [PubMed]

114. Zhou, X.; Zhang, X.; Yang, Y.; Li, Z.; Du, L.; Dong, Z.; Qu, A.; Jiang, X.; Li, P.; Wang, C. Urinary cell-free microRNA-106b as a novel biomarker for detection of bladder cancer. Med. Oncol. 2014, 31, 197. [CrossRef] [PubMed]

115. Ji, T.; Zheng, Z.G.; Wang, F.M.; Xu, L.J.; Li, L.F.; Cheng, Q.H.; Guo, J.F.; Ding, X.F. Differential microRNA expression by Solexa sequencing in the sera of ovarian cancer patients. Asian Pac. J. Cancer Prev. 2014, 15, 1739-1743. [CrossRef] [PubMed]

116. Li, J.; Fu, R.; Yang, L.; Tu, W. miR-21 expression predicts prognosis in diffuse large B-cell lymphoma. Int. J. Clin. Exp. Pathol. 2015, 8, 15019-15024. [PubMed]

117. Chen, W.; Wang, H.; Chen, H.; Liu, S.; Lu, H.; Kong, D.; Huang, X.; Kong, Q.; Lu, Z. Clinical significance and detection of microRNA-21 in serum of patients with diffuse large B-cell lymphoma in Chinese population. Eur. J. Haematol. 2014, 92, 407-412. [CrossRef] [PubMed]

118. Jones, K.; Nourse, J.P.; Keane, C.; Bhatnagar, A.; Gandhi, M.K. Plasma microRNA are disease response biomarkers in classical Hodgkin lymphoma. Clin. Cancer Res. 2014, 20, 253-264. [CrossRef] [PubMed]

119. Mao, X.; Sun, Y.; Tang, J. Serum miR-21 is a diagnostic and prognostic marker of primary central nervous system lymphoma. Neurol. Sci. 2014, 35, 233-238. [CrossRef] [PubMed]

120. Kumar, S.; Keerthana, R.; Pazhanimuthu, A.; Perumal, P. Overexpression of circulating miRNA-21 and miRNA-146a in plasma samples of breast cancer patients. Indian J. Biochem. Biophys. 2013, 50, $210-214$. [PubMed]

121. Asaga, S.; Kuo, C.; Nguyen, T.; Terpenning, M.; Giuliano, A.E.; Hoon, D.S. Direct serum assay for microRNA-21 concentrations in early and advanced breast cancer. Clin. Chem. 2011, 57, 84-91. [CrossRef] [PubMed]

122. Toraih, E.A.; Mohammed, E.A.; Farrag, S.; Ramsis, N.; Hosny, S. Pilot Study of Serum MicroRNA-21 as a Diagnostic and Prognostic Biomarker in Egyptian Breast Cancer Patients. Mol. Diagn. Ther. 2015, 19, 179-190. [CrossRef] [PubMed]

123. Usmani, A.; Shoro, A.A.; Memon, Z.; Hussain, M.; Rehman, R. Diagnostic, prognostic and predictive value of MicroRNA-21 in breast cancer patients, their daughters and healthy individuals. Am. J. Cancer Res. 2015, 5, 2484-2490. [PubMed]

124. Wang, G.; Wang, L.; Sun, S.; Wu, J.; Wang, Q. Quantitative measurement of serum microRNA-21 expression in relation to breast cancer metastasis in Chinese females. Ann. Lab. Med. 2015, 35, 226-232. [CrossRef] [PubMed]

125. Matamala, N.; Vargas, M.T.; Gonzalez-Campora, R.; Minambres, R.; Arias, J.I.; Menendez, P.; Andres-Leon, E.; Gomez-Lopez, G.; Yanowsky, K.; Calvete-Candenas, J.; et al. Tumor microRNA expression profiling identifies circulating microRNAs for early breast cancer detection. Clin. Chem. 2015, 61, 1098-1106. [CrossRef] [PubMed]

126. Erbes, T.; Hirschfeld, M.; Rucker, G.; Jaeger, M.; Boas, J.; Iborra, S.; Mayer, S.; Gitsch, G.; Stickeler, E. Feasibility of urinary microRNA detection in breast cancer patients and its potential as an innovative non-invasive biomarker. BMC Cancer 2015, 15, 193. [CrossRef] [PubMed]

127. Ma, G.J.; Gu, R.M.; Zhu, M.; Wen, X.; Li, J.T.; Zhang, Y.Y.; Zhang, X.M.; Chen, S.Q. Plasma post-operative miR-21 expression in the prognosis of gastric cancers. Asian Pac. J. Cancer Prev. 2013, 14, 7551-7554. [CrossRef] [PubMed]

128. Song, J.; Bai, Z.; Zhang, J.; Meng, H.; Cai, J.; Deng, W.; Bi, J.; Ma, X.; Zhang, Z. Serum microRNA-21 levels are related to tumor size in gastric cancer patients but cannot predict prognosis. Oncol. Lett. 2013, 6, 1733-1737. [PubMed] 
129. Kim, S.Y.; Jeon, T.Y.; Choi, C.I.; Kim, D.H.; Kim, D.H.; Kim, G.H.; Ryu, D.Y.; Lee, B.E.; Kim, H.H. Validation of circulating miRNA biomarkers for predicting lymph node metastasis in gastric cancer. J. Mol. Diagn. 2013, 15, 661-669. [CrossRef] [PubMed]

130. Shiotani, A.; Murao, T.; Kimura, Y.; Matsumoto, H.; Kamada, T.; Kusunoki, H.; Inoue, K.; Uedo, N.; Iishi, H.; Haruma, K. Identification of serum miRNAs as novel non-invasive biomarkers for detection of high risk for early gastric cancer. Br. J. Cancer 2013, 109, 2323-2330. [CrossRef] [PubMed]

131. Komatsu, S.; Ichikawa, D.; Tsujiura, M.; Konishi, H.; Takeshita, H.; Nagata, H.; Kawaguchi, T.; Hirajima, S.; Arita, T.; Shiozaki, A.; et al. Prognostic impact of circulating miR-21 in the plasma of patients with gastric carcinoma. Anticancer Res. 2013, 33, 271-276. [PubMed]

132. Wu, J.; Li, G.; Wang, Z.; Yao, Y.; Chen, R.; Pu, X.; Wang, J. Circulating MicroRNA-21 Is a Potential Diagnostic Biomarker in Gastric Cancer. Dis. Markers 2015, 2015, 435656. [CrossRef] [PubMed]

133. Ilhan-Mutlu, A.; Wagner, L.; Wohrer, A.; Furtner, J.; Widhalm, G.; Marosi, C.; Preusser, M. Plasma MicroRNA-21 concentration may be a useful biomarker in glioblastoma patients. Cancer Investig. 2012, 30, 615-621. [CrossRef] [PubMed]

134. Xu, Y.Z.; Xi, Q.H.; Ge, W.L.; Zhang, X.Q. Identification of serum microRNA-21 as a biomarker for early detection and prognosis in human epithelial ovarian cancer. Asian Pac. J. Cancer Prev. 2013, 14, 1057-1060. [CrossRef] [PubMed]

135. Taylor, D.D.; Gercel-Taylor, C. MicroRNA signatures of tumor-derived exosomes as diagnostic biomarkers of ovarian cancer. Gynecol. Oncol. 2008, 110, 13-21. [CrossRef] [PubMed]

136. Wang, J.; Chen, J.; Chang, P.; LeBlanc, A.; Li, D.; Abbruzzesse, J.L.; Frazier, M.L.; Killary, A.M.; Sen, S. MicroRNAs in plasma of pancreatic ductal adenocarcinoma patients as novel blood-based biomarkers of disease. Cancer Prev. Res. (Phila) 2009, 2, 807-813. [CrossRef] [PubMed]

137. Abue, M.; Yokoyama, M.; Shibuya, R.; Tamai, K.; Yamaguchi, K.; Sato, I.; Tanaka, N.; Hamada, S.; Shimosegawa, T.; Sugamura, K.; et al. Circulating miR-483-3p and miR-21 is highly expressed in plasma of pancreatic cancer. Int. J. Oncol. 2015, 46, 539-547. [CrossRef] [PubMed]

138. Ali, S.; Dubaybo, H.; Brand, R.E.; Sarkar, F.H. Differential Expression of MicroRNAs in Tissues and Plasma Co-exists as a Biomarker for Pancreatic Cancer. J. Cancer Sci. Ther. 2015, 7, 336-346. [CrossRef] [PubMed]

139. Yang, J.Y.; Sun, Y.W.; Liu, D.J.; Zhang, J.F.; Li, J.; Hua, R. MicroRNAs in stool samples as potential screening biomarkers for pancreatic ductal adenocarcinoma cancer. Am. J. Cancer Res. 2014, 4, 663-673. [PubMed]

140. Que, R.; Ding, G.; Chen, J.; Cao, L. Analysis of serum exosomal microRNAs and clinicopathologic features of patients with pancreatic adenocarcinoma. World J. Surg. Oncol. 2013, 11, 219. [CrossRef] [PubMed]

141. Pan, W.; Tang, W.; Yuan, W.; Yu, Q.; Zuo, W.; Xu, C.; Ma, J. Expression and clinical significance of plasma small RNA in patients with pancreatic cancer. Zhonghua Zhong Liu Za Zhi 2014, 36, 351-354. [PubMed]

142. Humeau, M.; Vignolle-Vidoni, A.; Sicard, F.; Martins, F.; Bournet, B.; Buscail, L.; Torrisani, J.; Cordelier, P. Salivary MicroRNA in Pancreatic Cancer Patients. PLoS ONE 2015, 10, e0130996. [CrossRef] [PubMed]

143. Zhang, H.L.; Yang, L.F.; Zhu, Y.; Yao, X.D.; Zhang, S.L.; Dai, B.; Zhu, Y.P.; Shen, Y.J.; Shi, G.H.; Ye, D.W. Serum miRNA-21: Elevated levels in patients with metastatic hormone-refractory prostate cancer and potential predictive factor for the efficacy of docetaxel-based chemotherapy. Prostate 2011, 71, 326-331. [CrossRef] [PubMed]

144. Basati, G.; Emami Razavi, A.; Abdi, S.; Mirzaei, A. Elevated level of microRNA-21 in the serum of patients with colorectal cancer. Med. Oncol. 2014, 31, 205. [CrossRef] [PubMed]

145. Toiyama, Y.; Takahashi, M.; Hur, K.; Nagasaka, T.; Tanaka, K.; Inoue, Y.; Kusunoki, M.; Boland, C.R.; Goel, A. Serum miR-21 as a diagnostic and prognostic biomarker in colorectal cancer. J. Natl. Cancer Inst. 2013, 105, 849-859. [CrossRef] [PubMed]

146. Liu, G.H.; Zhou, Z.G.; Chen, R.; Wang, M.J.; Zhou, B.; Li, Y.; Sun, X.F. Serum miR-21 and miR-92a as biomarkers in the diagnosis and prognosis of colorectal cancer. Tumour Biol. 2013, 34, 2175-2181. [CrossRef] [PubMed]

147. Menendez, P.; Padilla, D.; Villarejo, P.; Palomino, T.; Nieto, P.; Menendez, J.M.; Rodriguez-Montes, J.A. Prognostic implications of serum microRNA-21 in colorectal cancer. J. Surg. Oncol. 2013, 108, 369-373. [CrossRef] [PubMed]

148. Beckett, E.L.; Martin, C.; Choi, J.H.; King, K.; Niblett, S.; Boyd, L.; Duesing, K.; Yates, Z.; Veysey, M.; Lucock, M. Folate status, folate-related genes and serum miR-21 expression: Implications for miR-21 as a biomarker. BBA Clin. 2015, 4, 45-51. [CrossRef] [PubMed] 
149. Yang, J.S.; Li, B.J.; Lu, H.W.; Chen, Y.; Lu, C.; Zhu, R.X.; Liu, S.H.; Yi, Q.T.; Li, J.; Song, C.H. Serum miR-152, miR-148a, miR-148b, and miR-21 as novel biomarkers in non-small cell lung cancer screening. Tumour Biol. 2015, 36, 3035-3042. [CrossRef] [PubMed]

150. Kim, J.O.; Gazala, S.; Razzak, R.; Guo, L.; Ghosh, S.; Roa, W.H.; Bedard, E.L. Non-small cell lung cancer detection using microRNA expression profiling of bronchoalveolar lavage fluid and sputum. Anticancer Res. 2015, 35, 1873-1880. [PubMed]

151. Zhao, W.; Zhao, J.J.; Zhang, L.; Xu, Q.F.; Zhao, Y.M.; Shi, X.Y.; Xu, A.G. Serum miR-21 level: A potential diagnostic and prognostic biomarker for non-small cell lung cancer. Int. J. Clin. Exp. Med. 2015, 8, 14759-14763. [PubMed]

152. Hsu, C.M.; Lin, P.M.; Wang, Y.M.; Chen, Z.J.; Lin, S.F.; Yang, M.Y. Circulating miRNA is a novel marker for head and neck squamous cell carcinoma. Tumour Biol. 2012, 33, 1933-1942. [CrossRef] [PubMed]

153. Komatsu, S.; Ichikawa, D.; Takeshita, H.; Tsujiura, M.; Morimura, R.; Nagata, H.; Kosuga, T.; Iitaka, D.; Konishi, H.; Shiozaki, A.; et al. Circulating microRNAs in plasma of patients with oesophageal squamous cell carcinoma. Br. J. Cancer 2011, 105, 104-111. [CrossRef] [PubMed]

154. Xie, Z.; Chen, G.; Zhang, X.; Li, D.; Huang, J.; Yang, C.; Zhang, P.; Qin, Y.; Duan, Y.; Gong, B.; et al. Salivary microRNAs as promising biomarkers for detection of esophageal cancer. PLoS ONE 2013, 8, e57502. [CrossRef] [PubMed]

155. Zhuang, C.; Jiang, W.; Huang, D.; Xu, L.; Yang, Q.; Zheng, L.; Wang, X.; Hu, L. Serum miR-21, miR-26a and miR-101 as potential biomarkers of hepatocellular carcinoma. Clin. Res. Hepatol. Gastroenterol. 2015. [CrossRef] [PubMed]

156. Yin, J.; Bai, Z.; Song, J.; Yang, Y.; Wang, J.; Han, W.; Zhang, J.; Meng, H.; Ma, X.; Yang, Y.; et al. Differential expression of serum miR-126, miR-141 and miR-21 as novel biomarkers for early detection of liver metastasis in colorectal cancer. Chin. J. Cancer Res. 2014, 26, 95-103. [PubMed]

157. Wang, H.; Hou, L.; Li, A.; Duan, Y.; Gao, H.; Song, X. Expression of serum exosomal microRNA-21 in human hepatocellular carcinoma. BioMed Res. Int. 2014, 2014, 864894. [CrossRef] [PubMed]

158. Amr, K.S.; Ezzat, W.M.; Elhosary, Y.A.; Hegazy, A.E.; Fahim, H.H.; Kamel, R.R. The potential role of miRNAs 21 and 199-a in early diagnosis of hepatocellular carcinoma. Gene 2016, 575, 66-70. [CrossRef] [PubMed]

159. Kishimoto, T.; Eguchi, H.; Nagano, H.; Kobayashi, S.; Akita, H.; Hama, N.; Wada, H.; Kawamoto, K.; Tomokuni, A.; Tomimaru, Y.; et al. Plasma miR-21 is a novel diagnostic biomarker for biliary tract cancer. Cancer Sci. 2013, 104, 1626-1631. [CrossRef] [PubMed]

160. Liu, X.; Luo, H.N.; Tian, W.D.; Lu, J.; Li, G.; Wang, L.; Zhang, B.; Liang, B.J.; Peng, X.H.; Lin, S.X.; et al. Diagnostic and prognostic value of plasma microRNA deregulation in nasopharyngeal carcinoma. Cancer Biol. Ther. 2013, 14, 1133-1142. [CrossRef] [PubMed]

161. Ouyang, L.; Liu, P.; Yang, S.; Ye, S.; Xu, W.; Liu, X. A three-plasma miRNA signature serves as novel biomarkers for osteosarcoma. Med. Oncol. 2013, 30, 340. [CrossRef] [PubMed]

162. Hong, Q.; Fang, J.; Pang, Y.; Zheng, J. Prognostic value of the microRNA-29 family in patients with primary osteosarcomas. Med. Oncol. 2014, 31, 37. [CrossRef] [PubMed]

163. Wang, L.G.; Gu, J. Serum microRNA-29a is a promising novel marker for early detection of colorectal liver metastasis. Cancer Epidemiol. 2012, 36, e61-e67. [CrossRef] [PubMed]

164. Brunet Vega, A.; Pericay, C.; Moya, I.; Ferrer, A.; Dotor, E.; Pisa, A.; Casalots, A.; Serra-Aracil, X.; Oliva, J.C.; Ruiz, A.; et al. microRNA expression profile in stage III colorectal cancer: Circulating miR-18a and miR-29a as promising biomarkers. Oncol. Rep. 2013, 30, 320-326. [CrossRef] [PubMed]

165. Wu, Q.; Wang, C.; Lu, Z.; Guo, L.; Ge, Q. Analysis of serum genome-wide microRNAs for breast cancer detection. Clin. Chim. Acta 2012, 413, 1058-1065. [CrossRef] [PubMed]

166. Wu, Q.; Lu, Z.; Li, H.; Lu, J.; Guo, L.; Ge, Q. Next-generation sequencing of microRNAs for breast cancer detection. J. Biomed. Biotechnol. 2011, 2011, 597145. [CrossRef] [PubMed]

167. Basati, G.; Razavi, A.E.; Pakzad, I.; Malayeri, F.A. Circulating levels of the miRNAs, miR-194, and miR-29b, as clinically useful biomarkers for colorectal cancer. Tumour Biol. 2015. [CrossRef] [PubMed]

168. Yang, I.P.; Tsai, H.L.; Huang, C.W.; Huang, M.Y.; Hou, M.F.; Juo, S.H.; Wang, J.Y. The functional significance of microRNA-29c in patients with colorectal cancer: A potential circulating biomarker for predicting early relapse. PLoS ONE 2013, 8, e66842. [CrossRef] [PubMed] 
169. Zhu, W.; He, J.; Chen, D.; Zhang, B.; Xu, L.; Ma, H.; Liu, X.; Zhang, Y.; Le, H. Expression of miR-29c, miR-93, and miR-429 as potential biomarkers for detection of early stage non-small lung cancer. PLoS ONE 2014, 9 , e87780. [CrossRef] [PubMed]

170. Zeng, X.; Xiang, J.; Wu, M.; Xiong, W.; Tang, H.; Deng, M.; Li, X.; Liao, Q.; Su, B.; Luo, Z.; et al. Circulating miR-17, miR-20a, miR-29c, and miR-223 combined as non-invasive biomarkers in nasopharyngeal carcinoma. PLoS ONE 2012, 7, e46367. [CrossRef] [PubMed]

171. Cazzoli, R.; Buttitta, F.; di Nicola, M.; Malatesta, S.; Marchetti, A.; Rom, W.N.; Pass, H.I. MicroRNAs derived from circulating exosomes as noninvasive biomarkers for screening and diagnosing lung cancer. J. Thorac. Oncol. 2013, 8, 1156-1162. [CrossRef] [PubMed]

172. Chiam, K.; Wang, T.; Watson, D.I.; Mayne, G.C.; Irvine, T.S.; Bright, T.; Smith, L.; White, I.A.; Bowen, J.M.; Keefe, D.; et al. Circulating Serum Exosomal miRNAs As Potential Biomarkers for Esophageal Adenocarcinoma. J. Gastrointest. Surg. 2015, 19, 1208-1215. [CrossRef] [PubMed]

173. Chen, Z.H.; Zhang, G.L.; Li, H.R.; Luo, J.D.; Li, Z.X.; Chen, G.M.; Yang, J. A panel of five circulating microRNAs as potential biomarkers for prostate cancer. Prostate 2012, 72, 1443-1452. [CrossRef] [PubMed]

174. Kachakova, D.; Mitkova, A.; Popov, E.; Popov, I.; Vlahova, A.; Dikov, T.; Christova, S.; Mitev, V.; Slavov, C.; Kaneva, R. Combinations of serum prostate-specific antigen and plasma expression levels of let-7c, miR-30c, miR-141, and miR-375 as potential better diagnostic biomarkers for prostate cancer. DNA Cell Biol. 2015, 34, 189-200. [CrossRef] [PubMed]

175. Rani, S.; Gately, K.; Crown, J.; O’Byrne, K.; O’Driscoll, L. Global analysis of serum microRNAs as potential biomarkers for lung adenocarcinoma. Cancer Biol. Ther. 2013, 14, 1104-1112. [CrossRef] [PubMed]

176. Le, H.B.; Zhu, W.Y.; Chen, D.D.; He, J.Y.; Huang, Y.Y.; Liu, X.G.; Zhang, Y.K. Evaluation of dynamic change of serum miR-21 and miR-24 in pre- and post-operative lung carcinoma patients. Med. Oncol. 2012, 29, 3190-3197. [CrossRef] [PubMed]

177. Hu, Z.; Chen, X.; Zhao, Y.; Tian, T.; Jin, G.; Shu, Y.; Chen, Y.; Xu, L.; Zen, K.; Zhang, C.; et al. Serum microRNA signatures identified in a genome-wide serum microRNA expression profiling predict survival of non-small-cell lung cancer. J. Clin. Oncol. 2010, 28, 1721-1726. [CrossRef] [PubMed]

178. Bhattacharya, S.; Steele, R.; Shrivastava, S.; Chakraborty, S.; di Bisceglie, A.M.; Ray, R.B. Serum miR-30e and miR-223 as Novel Noninvasive Biomarkers for Hepatocellular Carcinoma. Am. J. Pathol. 2016, 186, $242-247$. [CrossRef] [PubMed]

179. Franchina, T.; Amodeo, V.; Bronte, G.; Savio, G.; Ricciardi, G.R.; Picciotto, M.; Russo, A.; Giordano, A.; Adamo, V. Circulating miR-22, miR-24 and miR-34a as novel predictive biomarkers to pemetrexed-based chemotherapy in advanced non-small cell lung cancer. J. Cell. Physiol. 2014, 229, 97-99. [CrossRef] [PubMed]

180. Tian, Q.; Jia, J.; Ling, S.; Liu, Y.; Yang, S.; Shao, Z. A causal role for circulating miR-34b in osteosarcoma. Eur. J. Surg. Oncol. 2014, 40, 67-72. [CrossRef] [PubMed]

181. Liu, X.; Feng, J.; Tang, L.; Liao, L.; Xu, Q.; Zhu, S. The regulation and function of miR-21-FOXO3a-miR-34b/c signaling in breast cancer. Int. J. Mol. Sci. 2015, 16, 3148-3162. [CrossRef] [PubMed]

182. Liu, F.; Wang, X.; Li, J.; Gu, K.; Lv, L.; Zhang, S.; Che, D.; Cao, J.; Jin, S.; Yu, Y. MiR-34c-3p functions as a tumour suppressor by inhibiting eIF4E expression in non-small cell lung cancer. Cell Prolif. 2015, 48, 582-592. [CrossRef] [PubMed]

183. Park, N.J.; Zhou, H.; Elashoff, D.; Henson, B.S.; Kastratovic, D.A.; Abemayor, E.; Wong, D.T. Salivary microRNA: Discovery, characterization, and clinical utility for oral cancer detection. Clin. Cancer Res. 2009, 15, 5473-5477. [CrossRef] [PubMed]

184. Wang, R.J.; Zheng, Y.H.; Wang, P.; Zhang, J.Z. Serum miR-125a-5p, miR-145 and miR-146a as diagnostic biomarkers in non-small cell lung cancer. Int. J. Clin. Exp. Pathol. 2015, 8, 765-771. [PubMed]

185. Hsieh, T.H.; Hsu, C.Y.; Tsai, C.F.; Long, C.Y.; Chai, C.Y.; Hou, M.F.; Lee, J.N.; Wu, D.C.; Wang, S.C.; Tsai, E.M. $\mathrm{miR}-125 \mathrm{a}-5 \mathrm{p}$ is a prognostic biomarker that targets HDAC4 to suppress breast tumorigenesis. Oncotarget 2015, 6, 494-509. [CrossRef] [PubMed]

186. Zheng, J.; Zhou, Z.; Xu, Z.; Li, G.; Dong, P.; Chen, Z.; Lin, D.; Chen, B.; Yu, F. Serum microRNA-125a-5p, a useful biomarker in liver diseases, correlates with disease progression. Mol. Med. Rep. 2015, 12, 1584-1590. [CrossRef] [PubMed]

187. Wang, H.; Tan, G.; Dong, L.; Cheng, L.; Li, K.; Wang, Z.; Luo, H. Circulating miR-125b as a marker predicting chemoresistance in breast cancer. PLoS ONE 2012, 7, e34210. [CrossRef] [PubMed] 
188. Yuxia, M.; Zhennan, T.; Wei, Z. Circulating miR-125b is a novel biomarker for screening non-small-cell lung cancer and predicts poor prognosis. J. Cancer Res. Clin. Oncol. 2012, 138, 2045-2050. [CrossRef] [PubMed]

189. Cui, E.H.; Li, H.J.; Hua, F.; Wang, B.; Mao, W.; Feng, X.R.; Li, J.Y.; Wang, X. Serum microRNA 125b as a diagnostic or prognostic biomarker for advanced NSCLC patients receiving cisplatin-based chemotherapy. Acta Pharmacol. Sin. 2013, 34, 309-313. [CrossRef] [PubMed]

190. Gu, W.L.; Ye, D.X.; Wu, J.J. Expression and clinical significance of plasma microRNA-125b level in patients with oral squamous cell carcinoma. Shanghai Kou Qiang Yi Xue 2015, 24, 71-75. [PubMed]

191. Yamada, A.; Horimatsu, T.; Okugawa, Y.; Nishida, N.; Honjo, H.; Ida, H.; Kou, T.; Kusaka, T.; Sasaki, Y.; Yagi, M.; et al. Serum miR-21, miR-29a, and miR-125b Are Promising Biomarkers for the Early Detection of Colorectal Neoplasia. Clin. Cancer Res. 2015, 21, 4234-4242. [CrossRef] [PubMed]

192. Wei, X.; Chen, D.; Lv, T.; Li, G.; Qu, S. Serum MicroRNA-125b as a Potential Biomarker for Glioma Diagnosis. Mol. Neurobiol. 2016, 53, 163-170. [CrossRef] [PubMed]

193. Alegre, E.; Sanmamed, M.F.; Rodriguez, C.; Carranza, O.; Martin-Algarra, S.; Gonzalez, A. Study of circulating microRNA-125b levels in serum exosomes in advanced melanoma. Arch. Pathol. Lab. Med. 2014, 138, 828-832. [CrossRef] [PubMed]

194. Wang, F.; Hou, J.; Jin, W.; Li, J.; Yue, Y.; Jin, H.; Wang, X. Increased circulating microRNA-155 as a potential biomarker for breast cancer screening: A meta-analysis. Molecules 2014, 19, 6282-6293. [CrossRef] [PubMed]

195. Liu, J.; Mao, Q.; Liu, Y.; Hao, X.; Zhang, S.; Zhang, J. Analysis of miR-205 and miR-155 expression in the blood of breast cancer patients. Chin. J. Cancer Res. 2013, 25, 46-54. [PubMed]

196. Sun, Y.; Wang, M.; Lin, G.; Sun, S.; Li, X.; Qi, J.; Li, J. Serum microRNA-155 as a potential biomarker to track disease in breast cancer. PLoS ONE 2012, 7, e47003. [CrossRef] [PubMed]

197. Eichelser, C.; Flesch-Janys, D.; Chang-Claude, J.; Pantel, K.; Schwarzenbach, H. Deregulated serum concentrations of circulating cell-free microRNAs miR-17, miR-34a, miR-155, and miR-373 in human breast cancer development and progression. Clin. Chem. 2013, 59, 1489-1496. [CrossRef] [PubMed]

198. Lv, Z.C.; Fan, Y.S.; Chen, H.B.; Zhao, D.W. Investigation of microRNA-155 as a serum diagnostic and prognostic biomarker for colorectal cancer. Tumour Biol. 2015, 36, 1619-1625. [CrossRef] [PubMed]

199. Gao, F.; Chang, J.; Wang, H.; Zhang, G. Potential diagnostic value of miR-155 in serum from lung adenocarcinoma patients. Oncol. Rep. 2014, 31, 351-357. [PubMed]

200. Liu, R.; Liao, J.; Yang, M.; Shi, Y.; Peng, Y.; Wang, Y.; Pan, E.; Guo, W.; Pu, Y.; Yin, L. Circulating miR-155 expression in plasma: A potential biomarker for early diagnosis of esophageal cancer in humans. J. Toxicol. Environ. Health A 2012, 75, 1154-1162. [CrossRef] [PubMed]

201. Zhi, F.; Cao, X.; Xie, X.; Wang, B.; Dong, W.; Gu, W.; Ling, Y.; Wang, R.; Yang, Y.; Liu, Y. Identification of circulating microRNAs as potential biomarkers for detecting acute myeloid leukemia. PLoS ONE 2013, 8, e56718. [CrossRef] [PubMed]

202. Fang, C.; Zhu, D.X.; Dong, H.J.; Zhou, Z.J.; Wang, Y.H.; Liu, L.; Fan, L.; Miao, K.R.; Liu, P.; Xu, W.; et al. Serum microRNAs are promising novel biomarkers for diffuse large B cell lymphoma. Ann. Hematol. 2012, 91, 553-559. [CrossRef] [PubMed]

203. Ferrajoli, A.; Shanafelt, T.D.; Ivan, C.; Shimizu, M.; Rabe, K.G.; Nouraee, N.; Ikuo, M.; Ghosh, A.K.; Lerner, S.; Rassenti, L.Z.; et al. Prognostic value of miR-155 in individuals with monoclonal B-cell lymphocytosis and patients with B chronic lymphocytic leukemia. Blood 2013, 122, 1891-1899. [CrossRef] [PubMed]

204. Ishihara, K.; Sasaki, D.; Tsuruda, K.; Inokuchi, N.; Nagai, K.; Hasegawa, H.; Yanagihara, K.; Kamihira, S. Impact of miR-155 and miR-126 as novel biomarkers on the assessment of disease progression and prognosis in adult T-cell leukemia. Cancer Epidemiol. 2012, 36, 560-565. [CrossRef] [PubMed]

205. Zuberi, M.; Mir, R.; Das, J.; Ahmad, I.; Javid, J.; Yadav, P.; Masroor, M.; Ahmad, S.; Ray, P.C.; Saxena, A. Expression of serum miR-200a, miR-200b, and miR-200c as candidate biomarkers in epithelial ovarian cancer and their association with clinicopathological features. Clin. Transl. Oncol. 2015, 17, 779-787. [CrossRef] [PubMed]

206. Kan, C.W.; Hahn, M.A.; Gard, G.B.; Maidens, J.; Huh, J.Y.; Marsh, D.J.; Howell, V.M. Elevated levels of circulating microRNA-200 family members correlate with serous epithelial ovarian cancer. BMC Cancer 2012, 12, 627. [CrossRef] [PubMed]

207. Antolin, S.; Calvo, L.; Blanco-Calvo, M.; Santiago, M.P.; Lorenzo-Patino, M.J.; Haz-Conde, M.; Santamarina, I.; Figueroa, A.; Anton-Aparicio, L.M.; Valladares-Ayerbes, M. Circulating miR-200c and miR-141 and outcomes in patients with breast cancer. BMC Cancer 2015, 15, 297. [CrossRef] [PubMed] 
208. Gao, Y.C.; Wu, J. MicroRNA-200c and microRNA-141 as potential diagnostic and prognostic biomarkers for ovarian cancer. Tumour Biol. 2015, 36, 4843-4850. [CrossRef] [PubMed]

209. Lin, H.M.; Castillo, L.; Mahon, K.L.; Chiam, K.; Lee, B.Y.; Nguyen, Q.; Boyer, M.J.; Stockler, M.R.; Pavlakis, N.; Marx, G.; et al. Circulating microRNAs are associated with docetaxel chemotherapy outcome in castration-resistant prostate cancer. Br. J. Cancer 2014, 110, 2462-2471. [CrossRef] [PubMed]

210. Zhang, G.J.; Zhou, T.; Liu, Z.L.; Tian, H.P.; Xia, S.S. Plasma miR-200c and miR-18a as potential biomarkers for the detection of colorectal carcinoma. Mol. Clin. Oncol. 2013, 1, 379-384. [PubMed]

211. Toiyama, Y.; Hur, K.; Tanaka, K.; Inoue, Y.; Kusunoki, M.; Boland, C.R.; Goel, A. Serum miR-200c is a novel prognostic and metastasis-predictive biomarker in patients with colorectal cancer. Ann. Surg. 2014, 259, 735-743. [CrossRef] [PubMed]

212. Zhang, H.P.; Sun, F.B.; Li, S.J. Serum miR-200c expression level as a prognostic biomarker for gastric cancer. Genet. Mol. Res. 2015, 14, 15913-15920. [CrossRef] [PubMed]

213. Valladares-Ayerbes, M.; Reboredo, M.; Medina-Villaamil, V.; Iglesias-Diaz, P.; Lorenzo-Patino, M.J.; Haz, M.; Santamarina, I.; Blanco, M.; Fernandez-Tajes, J.; Quindos, M.; et al. Circulating miR-200c as a diagnostic and prognostic biomarker for gastric cancer. J. Transl. Med. 2012, 10, 186. [CrossRef] [PubMed]

214. Liu, X.G.; Zhu, W.Y.; Huang, Y.Y.; Ma, L.N.; Zhou, S.Q.; Wang, Y.K.; Zeng, F.; Zhou, J.H.; Zhang, Y.K. High expression of serum miR-21 and tumor miR-200c associated with poor prognosis in patients with lung cancer. Med. Oncol. 2012, 29, 618-626. [CrossRef] [PubMed]

215. Tanaka, K.; Miyata, H.; Yamasaki, M.; Sugimura, K.; Takahashi, T.; Kurokawa, Y.; Nakajima, K.; Takiguchi, S.; Mori, M.; Doki, Y. Circulating miR-200c levels significantly predict response to chemotherapy and prognosis of patients undergoing neoadjuvant chemotherapy for esophageal cancer. Ann. Surg. Oncol. 2013, 20, S607-S615. [CrossRef] [PubMed]

216. Kriebel, S.; Schmidt, D.; Holdenrieder, S.; Goltz, D.; Kristiansen, G.; Moritz, R.; Fisang, C.; Muller, S.C.; Ellinger, J. Analysis of tissue and serum microRNA expression in patients with upper urinary tract urothelial cancer. PLoS ONE 2015, 10, e0117284. [CrossRef] [PubMed]

217. Brase, J.C.; Johannes, M.; Schlomm, T.; Falth, M.; Haese, A.; Steuber, T.; Beissbarth, T.; Kuner, R.; Sultmann, H. Circulating miRNAs are correlated with tumor progression in prostate cancer. Int. J. Cancer 2011, 128, 608-616. [CrossRef] [PubMed]

218. Bryant, R.J.; Pawlowski, T.; Catto, J.W.; Marsden, G.; Vessella, R.L.; Rhees, B.; Kuslich, C.; Visakorpi, T.; Hamdy, F.C. Changes in circulating microRNA levels associated with prostate cancer. Br. J. Cancer. 2012, 106, 768-774. [CrossRef] [PubMed]

219. Li, Z.; Ma, Y.Y.; Wang, J.; Zeng, X.F.; Li, R.; Kang, W.; Hao, X.K. Exosomal microRNA-141 is upregulated in the serum of prostate cancer patients. Oncol. Targets Ther. 2016, 9, 139-148.

220. Zhang, H.L.; Qin, X.J.; Cao, D.L.; Zhu, Y.; Yao, X.D.; Zhang, S.L.; Dai, B.; Ye, D.W. An elevated serum miR-141 level in patients with bone-metastatic prostate cancer is correlated with more bone lesions. Asian J. Androl. 2013, 15, 231-235. [CrossRef] [PubMed]

221. Cheng, H.; Zhang, L.; Cogdell, D.E.; Zheng, H.; Schetter, A.J.; Nykter, M.; Harris, C.C.; Chen, K.; Hamilton, S.R.; Zhang, W. Circulating plasma miR-141 is a novel biomarker for metastatic colon cancer and predicts poor prognosis. PLoS ONE 2011, 6, e17745. [CrossRef] [PubMed]

222. Ho, A.S.; Huang, X.; Cao, H.; Christman-Skieller, C.; Bennewith, K.; Le, Q.T.; Koong, A.C. Circulating miR-210 as a Novel Hypoxia Marker in Pancreatic Cancer. Transl. Oncol. 2010, 3, 109-113. [CrossRef] [PubMed]

223. Zhao, A.; Li, G.; Peoc'h, M.; Genin, C.; Gigante, M. Serum miR-210 as a novel biomarker for molecular diagnosis of clear cell renal cell carcinoma. Exp. Mol. Pathol. 2013, 94, 115-120. [CrossRef] [PubMed]

224. Iwamoto, H.; Kanda, Y.; Sejima, T.; Osaki, M.; Okada, F.; Takenaka, A. Serum miR-210 as a potential biomarker of early clear cell renal cell carcinoma. Int. J. Oncol. 2014, 44, 53-58. [PubMed]

225. Jung, E.J.; Santarpia, L.; Kim, J.; Esteva, F.J.; Moretti, E.; Buzdar, A.U.; di Leo, A.; Le, X.F.; Bast, R.C., Jr.; Park, S.T.; et al. Plasma microRNA 210 levels correlate with sensitivity to trastuzumab and tumor presence in breast cancer patients. Cancer 2012, 118, 2603-2614. [CrossRef] [PubMed]

226. Wang, J.; Raimondo, M.; Guha, S.; Chen, J.; Diao, L.; Dong, X.; Wallace, M.B.; Killary, A.M.; Frazier, M.L.; Woodward, T.A.; et al. Circulating microRNAs in Pancreatic Juice as Candidate Biomarkers of Pancreatic Cancer. J. Cancer 2014, 5, 696-705. [CrossRef] [PubMed] 
227. Yang, Y.; Qu, A.; Liu, J.; Wang, R.; Liu, Y.; Li, G.; Duan, W.; Fang, Q.; Jiang, X.; Wang, L.; et al. Serum miR-210 Contributes to Tumor Detection, Stage Prediction and Dynamic Surveillance in Patients with Bladder Cancer. PLoS ONE 2015, 10, e0135168. [CrossRef] [PubMed]

228. Eissa, S.; Matboli, M.; Essawy, N.O.; Kotb, Y.M. Integrative functional genetic-epigenetic approach for selecting genes as urine biomarkers for bladder cancer diagnosis. Tumour Biol. 2015, 36, 9545-9552. [CrossRef] [PubMed]

229. Lai, N.S.; Wu, D.G.; Fang, X.G.; Lin, Y.C.; Chen, S.S.; Li, Z.B.; Xu, S.S. Serum microRNA-210 as a potential noninvasive biomarker for the diagnosis and prognosis of glioma. Br. J. Cancer 2015, 112, 1241-1246. [CrossRef] [PubMed]

230. Zhan, M.; Li, Y.; Hu, B.; He, X.; Huang, J.; Zhao, Y.; Fu, S.; Lu, L. Serum microRNA-210 as a predictive biomarker for treatment response and prognosis in patients with hepatocellular carcinoma undergoing transarterial chemoembolization. J. Vasc. Int. Radiol. 2014, 25, 1279-1287. [CrossRef] [PubMed]

231. Pu, X.X.; Huang, G.L.; Guo, H.Q.; Guo, C.C.; Li, H.; Ye, S.; Ling, S.; Jiang, L.; Tian, Y.; Lin, T.Y. Circulating miR-221 directly amplified from plasma is a potential diagnostic and prognostic marker of colorectal cancer and is correlated with p53 expression. J. Gastroenterol. Hepatol. 2010, 25, 1674-1680. [CrossRef] [PubMed]

232. Guo, H.Q.; Huang, G.L.; Guo, C.C.; Pu, X.X.; Lin, T.Y. Diagnostic and prognostic value of circulating miR-221 for extranodal natural killer/T-cell lymphoma. Dis. Markers 2010, 29, 251-258. [CrossRef] [PubMed]

233. Yilmaz, S.S.; Guzel, E.; Karatas, O.F.; Yilmaz, M.; Creighton, C.J.; Ozen, M. MiR-221 as a pre- and postoperative plasma biomarker for larynx cancer patients. Laryngoscope 2015, 125, E377-E381. [CrossRef] [PubMed]

234. Zhang, R.; Pang, B.; Xin, T.; Guo, H.; Xing, Y.; Xu, S.; Feng, B.; Liu, B.; Pang, Q. Plasma miR-221/222 Family as Novel Descriptive and Prognostic Biomarkers for Glioma. Mol. Neurobiol. 2015. [CrossRef] [PubMed]

235. Li, P.; He, Q.Y.; Luo, C.Q.; Qian, L.Y. Circulating miR-221 expression level and prognosis of cutaneous malignant melanoma. Med. Sci. Monit. 2014, 20, 2472-2477. [PubMed]

236. Teixeira, A.L.; Ferreira, M.; Silva, J.; Gomes, M.; Dias, F.; Santos, J.I.; Mauricio, J.; Lobo, F.; Medeiros, R. Higher circulating expression levels of miR-221 associated with poor overall survival in renal cell carcinoma patients. Tumour Biol. 2014, 35, 4057-4066. [CrossRef] [PubMed]

237. Wu, X.; Somlo, G.; Yu, Y.; Palomares, M.R.; Li, A.X.; Zhou, W.; Chow, A.; Yen, Y.; Rossi, J.J.; Gao, H.; et al. De novo sequencing of circulating miRNAs identifies novel markers predicting clinical outcome of locally advanced breast cancer. J. Transl. Med. 2012, 10, 42. [CrossRef] [PubMed]

238. Yu, H.; Jiang, L.; Sun, C.; Guo, L.; Lin, M.; Huang, J.; Zhu, L. Decreased circulating miR-375: A potential biomarker for patients with non-small-cell lung cancer. Gene 2014, 534, 60-65. [CrossRef] [PubMed]

239. Nguyen, H.C.; Xie, W.; Yang, M.; Hsieh, C.L.; Drouin, S.; Lee, G.S.; Kantoff, P.W. Expression differences of circulating microRNAs in metastatic castration resistant prostate cancer and low-risk, localized prostate cancer. Prostate 2013, 73, 346-354. [CrossRef] [PubMed]

240. Huang, X.; Yuan, T.; Liang, M.; Du, M.; Xia, S.; Dittmar, R.; Wang, D.; See, W.; Costello, B.A.; Quevedo, F.; et al. Exosomal miR-1290 and miR-375 as prognostic markers in castration-resistant prostate cancer. Eur. Urol. 2015, 67, 33-41. [CrossRef] [PubMed]

241. Wu, C.; Li, M.; Hu, C.; Duan, H. Clinical significance of serum miR-223, miR-25 and miR-375 in patients with esophageal squamous cell carcinoma. Mol. Biol. Rep. 2014, 41, 1257-1266. [CrossRef] [PubMed]

242. Yin, J.; Hou, P.; Wu, Z.; Wang, T.; Nie, Y. Circulating miR-375 and miR-199a-3p as potential biomarkers for the diagnosis of hepatocellular carcinoma. Tumour Biol. 2015, 36, 4501-4507. [CrossRef] [PubMed]

243. Xu, L.; Li, M.; Wang, M.; Yan, D.; Feng, G.; An, G. The expression of microRNA-375 in plasma and tissue is matched in human colorectal cancer. BMC Cancer 2014, 14, 714. [CrossRef] [PubMed]

244. Roush, S.; Slack, F.J. The let-7 family of microRNAs. Trends Cell Biol. 2008, 18, 505-516. [CrossRef] [PubMed]

245. Boyerinas, B.; Park, S.M.; Hau, A.; Murmann, A.E.; Peter, M.E. The role of let-7 in cell differentiation and cancer. Endocr. Relat. Cancer 2010, 17, F19-F36. [CrossRef] [PubMed]

246. Johnson, S.M.; Grosshans, H.; Shingara, J.; Byrom, M.; Jarvis, R.; Cheng, A.; Labourier, E.; Reinert, K.L.; Brown, D.; Slack, F.J. RAS is regulated by the let-7 microRNA family. Cell 2005, 120, 635-647. [CrossRef] [PubMed]

247. Kumar, M.S.; Erkeland, S.J.; Pester, R.E.; Chen, C.Y.; Ebert, M.S.; Sharp, P.A.; Jacks, T. Suppression of non-small cell lung tumor development by the let-7 microRNA family. Proc. Natl. Acad. Sci. USA 2008, 105, 3903-3908. [CrossRef] [PubMed] 
248. Mayr, C.; Hemann, M.T.; Bartel, D.P. Disrupting the pairing between let-7 and Hmga2 enhances oncogenic transformation. Science 2007, 315, 1576-1579. [CrossRef] [PubMed]

249. Lee, Y.S.; Dutta, A. The tumor suppressor microRNA let-7 represses the HMGA2 oncogene. Genes Dev. 2007, 21, 1025-1030. [CrossRef] [PubMed]

250. Wang, Y.; Lu, Y.; Toh, S.T.; Sung, W.K.; Tan, P.; Chow, P.; Chung, A.Y.; Jooi, L.L.; Lee, C.G. Lethal-7 is down-regulated by the hepatitis $\mathrm{B}$ virus $\mathrm{x}$ protein and targets signal transducer and activator of transcription 3. J. Hepatol. 2010, 53, 57-66. [CrossRef] [PubMed]

251. He, X.; Duan, C.; Chen, J.; Ou-Yang, X.; Zhang, Z.; Li, C.; Peng, H. Let-7a elevates p21(WAF1) levels by targeting of NIRF and suppresses the growth of A549 lung cancer cells. FEBS Lett. 2009, 583, 3501-3507. [CrossRef] [PubMed]

252. Sampson, V.B.; Rong, N.H.; Han, J.; Yang, Q.; Aris, V.; Soteropoulos, P.; Petrelli, N.J.; Dunn, S.P.; Krueger, L.J. MicroRNA let-7a down-regulates MYC and reverts MYC-induced growth in Burkitt lymphoma cells. Cancer Res. 2007, 67, 9762-9770. [CrossRef] [PubMed]

253. Akao, Y.; Nakagawa, Y.; Naoe, T. let-7 microRNA functions as a potential growth suppressor in human colon cancer cells. Biol. Pharm. Bull. 2006, 29, 903-906. [CrossRef] [PubMed]

254. Kim, H.H.; Kuwano, Y.; Srikantan, S.; Lee, E.K.; Martindale, J.L.; Gorospe, M. HuR recruits let-7/RISC to repress c-Myc expression. Genes Dev. 2009, 23, 1743-1748. [CrossRef] [PubMed]

255. Legesse-Miller, A.; Elemento, O.; Pfau, S.J.; Forman, J.J.; Tavazoie, S.; Coller, H.A. Let-7 Overexpression leads to an increased fraction of cells in G2/M, direct down-regulation of Cdc34, and stabilization of Wee1 kinase in primary fibroblasts. J. Biol. Chem. 2009, 284, 6605-6609. [CrossRef] [PubMed]

256. Johnson, C.D.; Esquela-Kerscher, A.; Stefani, G.; Byrom, M.; Kelnar, K.; Ovcharenko, D.; Wilson, M.; Wang, X.; Shelton, J.; Shingara, J.; et al. The let-7 microRNA represses cell proliferation pathways in human cells. Cancer Res. 2007, 67, 7713-7722. [CrossRef] [PubMed]

257. Schultz, J.; Lorenz, P.; Gross, G.; Ibrahim, S.; Kunz, M. MicroRNA let-7b targets important cell cycle molecules in malignant melanoma cells and interferes with anchorage-independent growth. Cell Res. 2008, 18, 549-557. [CrossRef] [PubMed]

258. Tsang, W.P.; Kwok, T.T. Let-7a microRNA suppresses therapeutics-induced cancer cell death by targeting caspase-3. Apoptosis 2008, 13, 1215-1222. [CrossRef] [PubMed]

259. Tokumaru, S.; Suzuki, M.; Yamada, H.; Nagino, M.; Takahashi, T. Let-7 regulates Dicer expression and constitutes a negative feedback loop. Carcinogenesis 2008, 29, 2073-2077. [CrossRef] [PubMed]

260. Forman, J.J.; Legesse-Miller, A.; Coller, H.A. A search for conserved sequences in coding regions reveals that the let-7 microRNA targets Dicer within its coding sequence. Proc. Natl. Acad. Sci. USA 2008, 105, 14879-14884. [CrossRef] [PubMed]

261. Cookson, V.J.; Bentley, M.A.; Hogan, B.V.; Horgan, K.; Hayward, B.E.; Hazelwood, L.D.; Hughes, T.A. Circulating microRNA profiles reflect the presence of breast tumours but not the profiles of microRNAs within the tumours. Cell. Oncol. 2012, 35, 301-308. [CrossRef] [PubMed]

262. Fayyad-Kazan, H.; Bitar, N.; Najar, M.; Lewalle, P.; Fayyad-Kazan, M.; Badran, R.; Hamade, E.; Daher, A.; Hussein, N.; ElDirani, R.; et al. Circulating miR-150 and miR-342 in plasma are novel potential biomarkers for acute myeloid leukemia. J. Transl. Med. 2013, 11, 31. [CrossRef] [PubMed]

263. Joosse, S.A.; Muller, V.; Steinbach, B.; Pantel, K.; Schwarzenbach, H. Circulating cell-free cancer-testis MAGE-A RNA, BORIS RNA, let-7b and miR-202 in the blood of patients with breast cancer and benign breast diseases. Br. J. Cancer 2014, 111, 909-917. [CrossRef] [PubMed]

264. Ma, L.; Teruya-Feldstein, J.; Weinberg, R.A. Tumour invasion and metastasis initiated by microRNA-10b in breast cancer. Nature 2007, 449, 682-688. [CrossRef] [PubMed]

265. Sun, L.; Yan, W.; Wang, Y.; Sun, G.; Luo, H.; Zhang, J.; Wang, X.; You, Y.; Yang, Z.; Liu, N. MicroRNA-10b induces glioma cell invasion by modulating MMP-14 and uPAR expression via HOXD10. Brain Res. 2011, 1389, 9-18. [CrossRef] [PubMed]

266. Tian, Y.; Luo, A.; Cai, Y.; Su, Q.; Ding, F.; Chen, H.; Liu, Z. MicroRNA-10b promotes migration and invasion through KLF4 in human esophageal cancer cell lines. J. Biol. Chem. 2010, 285, 7986-7994. [CrossRef] [PubMed] 
267. Ibrahim, S.A.; Yip, G.W.; Stock, C.; Pan, J.W.; Neubauer, C.; Poeter, M.; Pupjalis, D.; Koo, C.Y.; Kelsch, R.; Schule, R.; et al. Targeting of syndecan-1 by microRNA miR-10b promotes breast cancer cell motility and invasiveness via a Rho-GTPase- and E-cadherin-dependent mechanism. Int. J. Cancer 2012, 131, E884-E896. [CrossRef] [PubMed]

268. Liao, C.G.; Kong, L.M.; Zhou, P.; Yang, X.L.; Huang, J.G.; Zhang, H.L.; Lu, N. miR-10b is overexpressed in hepatocellular carcinoma and promotes cell proliferation, migration and invasion through RhoC, uPAR and MMPs. J. Transl. Med. 2014, 12, 234. [CrossRef] [PubMed]

269. Liu, Z.; Zhu, J.; Cao, H.; Ren, H.; Fang, X. miR-10b promotes cell invasion through RhoC-AKT signaling pathway by targeting HOXD10 in gastric cancer. Int. J. Oncol. 2012, 40, 1553-1560. [PubMed]

270. Ma, Z.; Chen, Y.; Min, L.; Li, L.; Huang, H.; Li, J.; Yan, Q.; Song, P.; Dai, L.; Yao, X. Augmented miR-10b expression associated with depressed expression of its target gene KLF4 involved in gastric carcinoma. Int. J. Clin. Exp. Pathol. 2015, 8, 5071-5079. [PubMed]

271. Tsukerman, P.; Stern-Ginossar, N.; Gur, C.; Glasner, A.; Nachmani, D.; Bauman, Y.; Yamin, R.; Vitenshtein, A.; Stanietsky, N.; Bar-Mag, T.; et al. miR-10b downregulates the stress-induced cell surface molecule MICB, a critical ligand for cancer cell recognition by natural killer cells. Cancer Res. 2012, 72, 5463-5472. [CrossRef] [PubMed]

272. Zhang, L.; Sun, J.; Wang, B.; Ren, J.C.; Su, W.; Zhang, T. MicroRNA-10b Triggers the Epithelial-Mesenchymal Transition (EMT) of Laryngeal Carcinoma Hep-2 Cells by Directly Targeting the E-cadherin. Appl. Biochem. Biotechnol. 2015, 176, 33-44. [CrossRef] [PubMed]

273. Teplyuk, N.M.; Uhlmann, E.J.; Wong, A.H.; Karmali, P.; Basu, M.; Gabriely, G.; Jain, A.; Wang, Y.; Chiocca, E.A.; Stephens, R.; et al. MicroRNA-10b inhibition reduces E2F1-mediated transcription and miR-15/16 activity in glioblastoma. Oncotarget 2015, 6, 3770-3783. [CrossRef] [PubMed]

274. Biagioni, F.; Bossel Ben-Moshe, N.; Fontemaggi, G.; Canu, V.; Mori, F.; Antoniani, B.; di Benedetto, A.; Santoro, R.; Germoni, S.; de Angelis, F.; et al. miR-10b*, a master inhibitor of the cell cycle, is down-regulated in human breast tumours. EMBO Mol. Med. 2012, 4, 1214-1229. [CrossRef] [PubMed]

275. Liang, H.; Fu, Z.; Jiang, X.; Wang, N.; Wang, F.; Wang, X.; Zhang, S.; Wang, Y.; Yan, X.; Guan, W.X.; et al. miR-16 promotes the apoptosis of human cancer cells by targeting FEAT. BMC Cancer 2015, 15, 448. [CrossRef] [PubMed]

276. Chen, L.; Wang, Q.; Wang, G.D.; Wang, H.S.; Huang, Y.; Liu, X.M.; Cai, X.H. miR-16 inhibits cell proliferation by targeting IGF1R and the Raf1-MEK1/2-ERK1/2 pathway in osteosarcoma. FEBS Lett. 2013, 587, 1366-1372. [CrossRef] [PubMed]

277. Cai, C.K.; Zhao, G.Y.; Tian, L.Y.; Liu, L.; Yan, K.; Ma, Y.L.; Ji, Z.W.; Li, X.X.; Han, K.; Gao, J.; et al. miR-15a and miR-16-1 downregulate CCND1 and induce apoptosis and cell cycle arrest in osteosarcoma. Oncol. Rep. 2012, 28, 1764-1770. [PubMed]

278. Yang, T.Q.; Lu, X.J.; Wu, T.F.; Ding, D.D.; Zhao, Z.H.; Chen, G.L.; Xie, X.S.; Li, B.; Wei, Y.X.; Guo, L.C.; et al. MicroRNA-16 inhibits glioma cell growth and invasion through suppression of BCL2 and the nuclear factor-кB1/MMP9 signaling pathway. Cancer Sci. 2014, 105, 265-271. [CrossRef] [PubMed]

279. Zhu, Y.; Xia, Y.; Niu, H.; Chen, Y. miR-16 induced the suppression of cell apoptosis while promote proliferation in esophageal squamous cell carcinoma. Cell. Physiol. Biochem. 2014, 33, 1340-1348. [CrossRef] [PubMed]

280. He, Q.; Ren, X.; Chen, J.; Li, Y.; Tang, X.; Wen, X.; Yang, X.; Zhang, J.; Wang, Y.; Ma, J.; et al. miR-16 targets fibroblast growth factor 2 to inhibit NPC cell proliferation and invasion via PI3K/AKT and MAPK signaling pathways. Oncotarget 2015. [CrossRef]

281. Zubillaga-Guerrero, M.I.; Alarcon-Romero Ldel, C.; Illades-Aguiar, B.; Flores-Alfaro, E.; Bermudez-Morales, V.H.; Deas, J.; Peralta-Zaragoza, O. MicroRNA miR-16-1 regulates CCNE1 (cyclin E1) gene expression in human cervical cancer cells. Int. J. Clin. Exp. Med. 2015, 8, 15999-16006. [PubMed]

282. Ofir, M.; Hacohen, D.; Ginsberg, D. miR-15 and miR-16 are direct transcriptional targets of E2F1 that limit E2F-induced proliferation by targeting cyclin E. Mol. Cancer Res. 2011, 9, 440-447. [CrossRef] [PubMed]

283. Huang, N.; Wu, J.; Qiu, W.; Lyu, Q.; He, J.; Xie, W.; Xu, N.; Zhang, Y. miR-15a and miR-16 induce autophagy and enhance chemosensitivity of Camptothecin. Cancer Biol. Ther. 2015, 16, 941-948. [CrossRef] [PubMed]

284. Renjie, W.; Haiqian, L. miR-132, miR-15a and miR-16 synergistically inhibit pituitary tumor cell proliferation, invasion and migration by targeting Sox5. Cancer Lett. 2015, 356, 568-578. [CrossRef] [PubMed] 
285. Lewis, B.P.; Shih, I.H.; Jones-Rhoades, M.W.; Bartel, D.P.; Burge, C.B. Prediction of mammalian microRNA targets. Cell 2003, 115, 787-798. [CrossRef]

286. Takakura, S.; Mitsutake, N.; Nakashima, M.; Namba, H.; Saenko, V.A.; Rogounovitch, T.I.; Nakazawa, Y.; Hayashi, T.; Ohtsuru, A.; Yamashita, S. Oncogenic role of miR-17-92 cluster in anaplastic thyroid cancer cells. Cancer Sci. 2008, 99, 1147-1154. [CrossRef] [PubMed]

287. Dews, M.; Fox, J.L.; Hultine, S.; Sundaram, P.; Wang, W.; Liu, Y.Y.; Furth, E.; Enders, G.H.; El-Deiry, W.; Schelter, J.M.; et al. The myc-miR-17 92 axis blunts TGF $\beta$ signaling and production of multiple TGF \{beta\}-dependent antiangiogenic factors. Cancer Res. 2010, 70, 8233-8246. [CrossRef] [PubMed]

288. Mestdagh, P.; Bostrom, A.K.; Impens, F.; Fredlund, E.; van Peer, G.; de Antonellis, P.; von Stedingk, K.; Ghesquiere, B.; Schulte, S.; Dews, M.; et al. The miR-17-92 microRNA cluster regulates multiple components of the TGF- $\beta$ pathway in neuroblastoma. Mol. Cell 2010, 40, 762-773. [CrossRef] [PubMed]

289. Petrocca, F.; Vecchione, A.; Croce, C.M. Emerging role of miR-106b-25/miR-17-92 clusters in the control of transforming growth factor beta signaling. Cancer Res. 2008, 68, 8191-8194. [CrossRef] [PubMed]

290. Sokolova, V.; Fiorino, A.; Zoni, E.; Crippa, E.; Reid, J.F.; Gariboldi, M.; Pierotti, M.A. The Effects of miR-20a on p21: Two Mechanisms Blocking Growth Arrest in TGF- $\beta$-Responsive Colon Carcinoma. J. Cell. Physiol. 2015, 230, 3105-3114. [CrossRef] [PubMed]

291. Hong, L.; Lai, M.; Chen, M.; Xie, C.; Liao, R.; Kang, Y.J.; Xiao, C.; Hu, W.Y.; Han, J.; Sun, P. The miR-17-92 cluster of microRNAs confers tumorigenicity by inhibiting oncogene-induced senescence. Cancer Res. 2010, 70, 8547-8557. [CrossRef] [PubMed]

292. Zhang, G.J.; Li, J.S.; Zhou, H.; Xiao, H.X.; Li, Y.; Zhou, T. MicroRNA-106b promotes colorectal cancer cell migration and invasion by directly targeting DLC1. J. Exp. Clin. Cancer Res. 2015, 34, 73. [CrossRef] [PubMed]

293. Li, P.; Xu, Q.; Zhang, D.; Li, X.; Han, L.; Lei, J.; Duan, W.; Ma, Q.; Wu, Z.; Wang, Z. Upregulated miR-106a plays an oncogenic role in pancreatic cancer. FEBS Lett. 2014, 588, 705-712. [CrossRef] [PubMed]

294. Wang, Z.; Wang, B.; Shi, Y.; Xu, C.; Xiao, H.L.; Ma, L.N.; Xu, S.L.; Yang, L.; Wang, Q.L.; Dang, W.Q.; et al. Oncogenic miR-20a and miR-106a enhance the invasiveness of human glioma stem cells by directly targeting TIMP-2. Oncogene 2015, 34, 1407-1419. [CrossRef] [PubMed]

295. Woods, K.; Thomson, J.M.; Hammond, S.M. Direct regulation of an oncogenic micro-RNA cluster by E2F transcription factors. J. Biol. Chem. 2007, 282, 2130-2134. [CrossRef] [PubMed]

296. Prasad, R.; Katiyar, S.K. Down-regulation of miRNA-106b inhibits growth of melanoma cells by promoting G1-phase cell cycle arrest and reactivation of p21/WAF1/Cip1 protein. Oncotarget 2014, 5, 10636-10649. [CrossRef] [PubMed]

297. Dews, M.; Homayouni, A.; Yu, D.; Murphy, D.; Sevignani, C.; Wentzel, E.; Furth, E.E.; Lee, W.M.; Enders, G.H.; Mendell, J.T.; et al. Augmentation of tumor angiogenesis by a Myc-activated microRNA cluster. Nat. Genet. 2006, 38, 1060-1065. [CrossRef] [PubMed]

298. Zheng, G.; Du, L.; Yang, X.; Zhang, X.; Wang, L.; Yang, Y.; Li, J.; Wang, C. Serum microRNA panel as biomarkers for early diagnosis of colorectal adenocarcinoma. Br. J. Cancer 2014, 111, 1985-1992. [CrossRef] [PubMed]

299. Ohyashiki, K.; Umezu, T.; Yoshizawa, S.; Ito, Y.; Ohyashiki, M.; Kawashima, H.; Tanaka, M.; Kuroda, M.; Ohyashiki, J.H. Clinical impact of down-regulated plasma miR-92a levels in non-Hodgkin's lymphoma. PLoS ONE 2011, 6, e16408. [CrossRef] [PubMed]

300. Yoshizawa, S.; Ohyashiki, J.H.; Ohyashiki, M.; Umezu, T.; Suzuki, K.; Inagaki, A.; Iida, S.; Ohyashiki, K. Downregulated plasma miR-92a levels have clinical impact on multiple myeloma and related disorders. Blood Cancer J. 2012, 2, e53. [CrossRef] [PubMed]

301. Wen, Y.; Han, J.; Chen, J.; Dong, J.; Xia, Y.; Liu, J.; Jiang, Y.; Dai, J.; Lu, J.; Jin, G.; et al. Plasma miRNAs as early biomarkers for detecting hepatocellular carcinoma. Int. J. Cancer 2015, 137, 1679-1690. [CrossRef] [PubMed]

302. Buscaglia, L.E.; Li, Y. Apoptosis and the target genes of microRNA-21. Chin. J. Cancer 2011, 30, 371-380. [CrossRef] [PubMed]

303. Cmarik, J.L.; Min, H.; Hegamyer, G.; Zhan, S.; Kulesz-Martin, M.; Yoshinaga, H.; Matsuhashi, S.; Colburn, N.H. Differentially expressed protein Pdcd4 inhibits tumor promoter-induced neoplastic transformation. Proc. Natl. Acad. Sci. USA 1999, 96, 14037-14042. [CrossRef] [PubMed]

304. Jansen, A.P.; Camalier, C.E.; Colburn, N.H. Epidermal expression of the translation inhibitor programmed cell death 4 suppresses tumorigenesis. Cancer Res. 2005, 65, 6034-6041. [CrossRef] [PubMed] 
305. Leupold, J.H.; Yang, H.S.; Colburn, N.H.; Asangani, I.; Post, S.; Allgayer, H. Tumor suppressor Pdcd4 inhibits invasion/intravasation and regulates urokinase receptor (u-PAR) gene expression via Sp-transcription factors. Oncogene 2007, 26, 4550-4562. [CrossRef] [PubMed]

306. Papagiannakopoulos, T.; Shapiro, A.; Kosik, K.S. MicroRNA-21 targets a network of key tumor-suppressive pathways in glioblastoma cells. Cancer Res. 2008, 68, 8164-8172. [CrossRef] [PubMed]

307. Wickramasinghe, N.S.; Manavalan, T.T.; Dougherty, S.M.; Riggs, K.A.; Li, Y.; Klinge, C.M. Estradiol downregulates miR-21 expression and increases miR-21 target gene expression in MCF-7 breast cancer cells. Nucleic Acids Res. 2009, 37, 2584-2595. [PubMed]

308. Meng, F.; Henson, R.; Wehbe-Janek, H.; Ghoshal, K.; Jacob, S.T.; Patel, T. MicroRNA-21 regulates expression of the PTEN tumor suppressor gene in human hepatocellular cancer. Gastroenterology 2007, 133, 647-658. [CrossRef] [PubMed]

309. He, C.; Dong, X.; Zhai, B.; Jiang, X.; Dong, D.; Li, B.; Jiang, H.; Xu, S.; Sun, X. miR-21 mediates sorafenib resistance of hepatocellular carcinoma cells by inhibiting autophagy via the PTEN/Akt pathway. Oncotarget 2015, 6, 28867-28881. [PubMed]

310. Gabriely, G.; Wurdinger, T.; Kesari, S.; Esau, C.C.; Burchard, J.; Linsley, P.S.; Krichevsky, A.M. MicroRNA 21 promotes glioma invasion by targeting matrix metalloproteinase regulators. Mol. Cell. Biol. 2008, 28, 5369-5380. [CrossRef] [PubMed]

311. Sabatel, C.; Malvaux, L.; Bovy, N.; Deroanne, C.; Lambert, V.; Gonzalez, M.L.; Colige, A.; Rakic, J.M.; Noel, A.; Martial, J.A.; et al. MicroRNA-21 exhibits antiangiogenic function by targeting RhoB expression in endothelial cells. PLOS ONE 2011, 6, e16979. [CrossRef] [PubMed]

312. Zhu, S.; Si, M.L.; Wu, H.; Mo, Y.Y. MicroRNA-21 targets the tumor suppressor gene tropomyosin 1 (TPM1). J. Biol. Chem. 2007, 282, 14328-14336. [CrossRef] [PubMed]

313. Garzon, R.; Heaphy, C.E.; Havelange, V.; Fabbri, M.; Volinia, S.; Tsao, T.; Zanesi, N.; Kornblau, S.M.; Marcucci, G.; Calin, G.A.; et al. MicroRNA 29b functions in acute myeloid leukemia. Blood 2009, 114, 5331-5341. [CrossRef] [PubMed]

314. Oliveira, L.H.; Schiavinato, J.L.; Fraguas, M.S.; Lucena-Araujo, A.R.; Haddad, R.; Araujo, A.G.; Dalmazzo, L.F.; Rego, E.M.; Covas, D.T.; Zago, M.A.; et al. Potential roles of microRNA-29a in the molecular pathophysiology of T-cell acute lymphoblastic leukemia. Cancer Sci. 2015, 106, 1264-1277. [CrossRef] [PubMed]

315. Xu, L.; Xu, Y.; Jing, Z.; Wang, X.; Zha, X.; Zeng, C.; Chen, S.; Yang, L.; Luo, G.; Li, B.; et al. Altered expression pattern of miR-29a, miR-29b and the target genes in myeloid leukemia. Exp. Hematol. Oncol. 2014, 3, 17. [CrossRef] [PubMed]

316. Nguyen, T.; Kuo, C.; Nicholl, M.B.; Sim, M.S.; Turner, R.R.; Morton, D.L.; Hoon, D.S. Downregulation of microRNA-29c is associated with hypermethylation of tumor-related genes and disease outcome in cutaneous melanoma. Epigenetics 2011, 6, 388-394. [CrossRef] [PubMed]

317. Lin, L.L.; Wang, W.; Hu, Z.; Wang, L.W.; Chang, J.; Qian, H. Negative feedback of miR-29 family TET1 involves in hepatocellular cancer. Med. Oncol. 2014, 31, 291. [CrossRef] [PubMed]

318. Xiong, Y.; Fang, J.H.; Yun, J.P.; Yang, J.; Zhang, Y.; Jia, W.H.; Zhuang, S.M. Effects of microRNA-29 on apoptosis, tumorigenicity, and prognosis of hepatocellular carcinoma. Hepatology 2010, 51, 836-845. [CrossRef] [PubMed]

319. Inoue, A.; Yamamoto, H.; Uemura, M.; Nishimura, J.; Hata, T.; Takemasa, I.; Ikenaga, M.; Ikeda, M.; Murata, K.; Mizushima, T.; et al. MicroRNA-29b is a Novel Prognostic Marker in Colorectal Cancer. Ann. Surg. Oncol. 2015, 22, 1410-1418. [CrossRef] [PubMed]

320. Li, Y.; Wang, F.; Xu, J.; Ye, F.; Shen, Y.; Zhou, J.; Lu, W.; Wan, X.; Ma, D.; Xie, X. Progressive miRNA expression profiles in cervical carcinogenesis and identification of HPV-related target genes for miR-29. J. Pathol. 2011, 224, 484-495. [CrossRef] [PubMed]

321. Wu, D.W.; Hsu, N.Y.; Wang, Y.C.; Lee, M.C.; Cheng, Y.W.; Chen, C.Y.; Lee, H. c-Myc suppresses microRNA-29b to promote tumor aggressiveness and poor outcomes in non-small cell lung cancer by targeting FHIT. Oncogene 2015, 34, 2072-2082. [CrossRef] [PubMed]

322. Nishikawa, R.; Goto, Y.; Kojima, S.; Enokida, H.; Chiyomaru, T.; Kinoshita, T.; Sakamoto, S.; Fuse, M.; Nakagawa, M.; Naya, Y.; et al. Tumor-suppressive microRNA-29s inhibit cancer cell migration and invasion via targeting LAMC1 in prostate cancer. Int. J. Oncol. 2014, 45, 401-410. [CrossRef] [PubMed] 
323. Zhao, J.J.; Lin, J.; Lwin, T.; Yang, H.; Guo, J.; Kong, W.; Dessureault, S.; Moscinski, L.C.; Rezania, D.; Dalton, W.S.; et al. microRNA expression profile and identification of miR-29 as a prognostic marker and pathogenetic factor by targeting CDK6 in mantle cell lymphoma. Blood 2010, 115, 2630-2639. [CrossRef] [PubMed]

324. Park, S.Y.; Lee, J.H.; Ha, M.; Nam, J.W.; Kim, V.N. MiR-29 miRNAs activate p53 by targeting p85 $\alpha$ and CDC42. Nat. Struct. Mol. Biol. 2009, 16, 23-29. [CrossRef] [PubMed]

325. Ye, Z.; Zhao, L.; Li, J.; Chen, W.; Li, X. MiR-30d Blocked Transforming Growth Factor $\beta 1$-Induced Epithelial-Mesenchymal Transition by Targeting Snail in Ovarian Cancer Cells. Int. J. Gynecol. Cancer 2015, 25, 1574-1581. [CrossRef] [PubMed]

326. Zhang, N.; Wang, X.; Huo, Q.; Sun, M.; Cai, C.; Liu, Z.; Hu, G.; Yang, Q. MicroRNA-30a suppresses breast tumor growth and metastasis by targeting metadherin. Oncogene 2014, 33, 3119-3128. [CrossRef] [PubMed]

327. Jiang, B.Y.; Zhang, X.C.; Su, J.; Meng, W.; Yang, X.N.; Yang, J.J.; Zhou, Q.; Chen, Z.Y.; Chen, Z.H.; Xie, Z.; et al. BCL11A overexpression predicts survival and relapse in non-small cell lung cancer and is modulated by microRNA-30a and gene amplification. Mol. Cancer 2013, 12, 61. [CrossRef] [PubMed]

328. Zhong, M.; Bian, Z.; Wu, Z. miR-30a suppresses cell migration and invasion through downregulation of PIK3CD in colorectal carcinoma. Cell. Physiol. Biochem. 2013, 31, 209-218. [CrossRef] [PubMed]

329. Zhong, K.; Chen, K.; Han, L.; Li, B. MicroRNA-30b/c inhibits non-small cell lung cancer cell proliferation by targeting Rab18. BMC Cancer 2014, 14, 703. [CrossRef] [PubMed]

330. Zhang, Q.; Tang, Q.; Qin, D.; Yu, L.; Huang, R.; Lv, G.; Zou, Z.; Jiang, X.C.; Zou, C.; Liu, W.; et al. Role of microRNA 30a targeting insulin receptor substrate 2 in colorectal tumorigenesis. Mol. Cell. Biol. 2015, 35, 988-1000. [CrossRef] [PubMed]

331. Wang, T.; Li, F.; Tang, S. MiR-30a upregulates BCL2A1, IER3 and cyclin D2 expression by targeting FOXL2. Oncol. Lett. 2015, 9, 967-971. [PubMed]

332. Kao, C.J.; Martiniez, A.; Shi, X.B.; Yang, J.; Evans, C.P.; Dobi, A.; deVere White, R.W.; Kung, H.J. miR-30 as a tumor suppressor connects EGF/Src signal to ERG and EMT. Oncogene 2014, 33, 2495-2503. [CrossRef] [PubMed]

333. Ouzounova, M.; Vuong, T.; Ancey, P.B.; Ferrand, M.; Durand, G.; Le-Calvez Kelm, F.; Croce, C.; Matar, C.; Herceg, Z.; Hernandez-Vargas, H. MicroRNA miR-30 family regulates non-attachment growth of breast cancer cells. BMC Genom. 2013, 14, 139. [CrossRef] [PubMed]

334. Bridge, G.; Monteiro, R.; Henderson, S.; Emuss, V.; Lagos, D.; Georgopoulou, D.; Patient, R.; Boshoff, C. The microRNA-30 family targets DLL4 to modulate endothelial cell behavior during angiogenesis. Blood 2012, 120, 5063-5072. [CrossRef] [PubMed]

335. Maroof, H.; Salajegheh, A.; Smith, R.A.; Lam, A.K. Role of microRNA-34 family in cancer with particular reference to cancer angiogenesis. Exp. Mol. Pathol. 2014, 97, 298-304. [CrossRef] [PubMed]

336. Ghandadi, M.; Sahebkar, A. MicroRNA-34a and its target genes: Key factors in cancer multidrug resistance. Curr. Pharm. Des. 2016, 22, 933-939. [CrossRef] [PubMed]

337. Navarro, F.; Lieberman, J. miR-34 and p53: New Insights into a Complex Functional Relationship. PLoS ONE 2015, 10, e0132767. [CrossRef] [PubMed]

338. Choi, Y.J.; Lin, C.P.; Ho, J.J.; He, X.; Okada, N.; Bu, P.; Zhong, Y.; Kim, S.Y.; Bennett, M.J.; Chen, C.; et al. miR-34 miRNAs provide a barrier for somatic cell reprogramming. Nat. Cell Biol. 2011, 13, 1353-1360. [CrossRef] [PubMed]

339. De Antonellis, P.; Medaglia, C.; Cusanelli, E.; Andolfo, I.; Liguori, L.; de Vita, G.; Carotenuto, M.; Bello, A.; Formiggini, F.; Galeone, A.; et al. miR-34a targeting of Notch ligand delta-like 1 impairs CD15 ${ }^{+} / \mathrm{CD} 133^{+}$ tumor-propagating cells and supports neural differentiation in medulloblastoma. PLoS ONE 2011, 6, e24584. [CrossRef] [PubMed]

340. Cha, Y.H.; Kim, N.H.; Park, C.; Lee, I.; Kim, H.S.; Yook, J.I. MiRNA-34 intrinsically links p53 tumor suppressor and Wnt signaling. Cell Cycle 2012, 11, 1273-1281. [CrossRef] [PubMed]

341. Siemens, H.; Jackstadt, R.; Hunten, S.; Kaller, M.; Menssen, A.; Gotz, U.; Hermeking, H. miR-34 and SNAIL form a double-negative feedback loop to regulate epithelial-mesenchymal transitions. Cell Cycle 2011, 10, 4256-4271. [CrossRef] [PubMed]

342. Brzozowa, M.; Mielanczyk, L.; Michalski, M.; Malinowski, L.; Kowalczyk-Ziomek, G.; Helewski, K.; Harabin-Slowinska, M.; Wojnicz, R. Role of Notch signaling pathway in gastric cancer pathogenesis. Contemp. Oncol. (Pozn) 2013, 17, 1-5. [CrossRef] [PubMed] 
343. Bae, Y.; Yang, T.; Zeng, H.C.; Campeau, P.M.; Chen, Y.; Bertin, T.; Dawson, B.C.; Munivez, E.; Tao, J.; Lee, B.H. miRNA-34c regulates Notch signaling during bone development. Hum. Mol. Genet. 2012, 21, 2991-3000. [CrossRef] [PubMed]

344. Guan, Y.; Yao, H.; Zheng, Z.; Qiu, G.; Sun, K. miR-125b targets BCL3 and suppresses ovarian cancer proliferation. Int. J. Cancer 2011, 128, 2274-2283. [CrossRef] [PubMed]

345. Huang, L.; Luo, J.; Cai, Q.; Pan, Q.; Zeng, H.; Guo, Z.; Dong, W.; Huang, J.; Lin, T. MicroRNA-125b suppresses the development of bladder cancer by targeting E2F3. Int. J. Cancer 2011, 128, 1758-1769. [CrossRef] [PubMed]

346. Li, W.; Duan, R.; Kooy, F.; Sherman, S.L.; Zhou, W.; Jin, P. Germline mutation of microRNA-125a is associated with breast cancer. J. Med. Genet. 2009, 46, 358-360. [CrossRef] [PubMed]

347. Zhou, M.; Liu, Z.; Zhao, Y.; Ding, Y.; Liu, H.; Xi, Y.; Xiong, W.; Li, G.; Lu, J.; Fodstad, O.; et al. MicroRNA-125b confers the resistance of breast cancer cells to paclitaxel through suppression of pro-apoptotic Bcl-2 antagonist killer 1 (Bak1) expression. J. Biol. Chem. 2010, 285, 21496-21507. [CrossRef] [PubMed]

348. Bi, Q.; Tang, S.; Xia, L.; Du, R.; Fan, R.; Gao, L.; Jin, J.; Liang, S.; Chen, Z.; Xu, G.; et al. Ectopic expression of MiR-125a inhibits the proliferation and metastasis of hepatocellular carcinoma by targeting MMP11 and VEGF. PLoS ONE 2012, 7, e40169. [CrossRef] [PubMed]

349. Liang, L.; Wong, C.M.; Ying, Q.; Fan, D.N.; Huang, S.; Ding, J.; Yao, J.; Yan, M.; Li, J.; Yao, M.; et al. MicroRNA-125b suppressesed human liver cancer cell proliferation and metastasis by directly targeting oncogene LIN28B2. Hepatology 2010, 52, 1731-1740. [CrossRef] [PubMed]

350. Jia, H.Y.; Wang, Y.X.; Yan, W.T.; Li, H.Y.; Tian, Y.Z.; Wang, S.M.; Zhao, H.L. MicroRNA-125b functions as a tumor suppressor in hepatocellular carcinoma cells. Int. J. Mol. Sci. 2012, 13, 8762-8774. [CrossRef] [PubMed]

351. Kappelmann, M.; Kuphal, S.; Meister, G.; Vardimon, L.; Bosserhoff, A.K. MicroRNA miR-125b controls melanoma progression by direct regulation of c-Jun protein expression. Oncogene 2013, 32, 2984-2991. [CrossRef] [PubMed]

352. Xu, N.; Zhang, L.; Meisgen, F.; Harada, M.; Heilborn, J.; Homey, B.; Grander, D.; Stahle, M.; Sonkoly, E.; Pivarcsi, A. MicroRNA-125b down-regulates matrix metallopeptidase 13 and inhibits cutaneous squamous cell carcinoma cell proliferation, migration, and invasion. J. Biol. Chem. 2012, 287, 29899-29908. [CrossRef] [PubMed]

353. Liu, L.H.; Li, H.; Li, J.P.; Zhong, H.; Zhang, H.C.; Chen, J.; Xiao, T. miR-125b suppresses the proliferation and migration of osteosarcoma cells through down-regulation of STAT3. Biochem. Biophys. Res. Commun. 2011, 416, 31-38. [CrossRef] [PubMed]

354. Gong, J.; Zhang, J.P.; Li, B.; Zeng, C.; You, K.; Chen, M.X.; Yuan, Y.; Zhuang, S.M. MicroRNA-125b promotes apoptosis by regulating the expression of Mcl-1, Bcl-w and IL-6R. Oncogene 2013, 32, 3071-3079. [CrossRef] [PubMed]

355. Zhao, A.; Zeng, Q.; Xie, X.; Zhou, J.; Yue, W.; Li, Y.; Pei, X. MicroRNA-125b induces cancer cell apoptosis through suppression of Bcl-2 expression. J. Genet. Genom. 2012, 39, 29-35. [CrossRef] [PubMed]

356. Pang, Y.; Young, C.Y.; Yuan, H. MicroRNAs and prostate cancer. Acta Biochim. Biophys. Sin. (Shanghai) 2010, 42, 363-369. [CrossRef] [PubMed]

357. Mashima, R. Physiological roles of miR-155. Immunology 2015, 145, 323-333. [CrossRef] [PubMed]

358. Seddiki, N.; Brezar, V.; Ruffin, N.; Levy, Y.; Swaminathan, S. Role of miR-155 in the regulation of lymphocyte immune function and disease. Immunology 2014, 142, 32-38. [CrossRef] [PubMed]

359. George, J.; Lewis, M.G.; Renne, R.; Mattapallil, J.J. Suppression of transforming growth factor beta receptor 2 and Smad5 is associated with high levels of microRNA miR-155 in the oral mucosa during chronic simian immunodeficiency virus infection. J. Virol. 2015, 89, 2972-2978. [CrossRef] [PubMed]

360. Yao, R.; Ma, Y.L.; Liang, W.; Li, H.H.; Ma, Z.J.; Yu, X.; Liao, Y.H. MicroRNA-155 modulates Treg and Th17 cells differentiation and Th17 cell function by targeting SOCS1. PLoS ONE 2012, 7, e46082. [CrossRef] [PubMed]

361. Xue, H.; Hua, L.M.; Guo, M.; Luo, J.M. SHIP1 is targeted by miR-155 in acute myeloid leukemia. Oncol. Rep. 2014, 32, 2253-2259. [CrossRef] [PubMed]

362. Salemi, D.; Cammarata, G.; Agueli, C.; Augugliaro, L.; Corrado, C.; Bica, M.G.; Raimondo, S.; Marfia, A.; Randazzo, V.; Dragotto, P.; et al. miR-155 regulative network in FLT3 mutated acute myeloid leukemia. Leuk. Res. 2015, 39, 883-896. [CrossRef] [PubMed] 
363. Wei, Y.; Zhu, M.; Corbalan-Campos, J.; Heyll, K.; Weber, C.; Schober, A. Regulation of Csf1r and Bcl6 in macrophages mediates the stage-specific effects of microRNA-155 on atherosclerosis. Arterioscler. Thromb. Vasc. Biol. 2015, 35, 796-803. [CrossRef] [PubMed]

364. De Santis, R.; Liepelt, A.; Mossanen, J.C.; Dueck, A.; Simons, N.; Mohs, A.; Trautwein, C.; Meister, G.; Marx, G.; Ostareck-Lederer, A.; et al. miR-155 targets Caspase-3 mRNA in activated macrophages. RNA Biol. 2016, 13, 43-58. [CrossRef] [PubMed]

365. Wang, H.Q.; Yu, X.D.; Liu, Z.H.; Cheng, X.; Samartzis, D.; Jia, L.T.; Wu, S.X.; Huang, J.; Chen, J.; Luo, Z.J. Deregulated miR-155 promotes Fas-mediated apoptosis in human intervertebral disc degeneration by targeting FADD and caspase-3. J. Pathol. 2011, 225, 232-242. [CrossRef] [PubMed]

366. Zang, Y.S.; Zhong, Y.F.; Fang, Z.; Li, B.; An, J. miR-155 inhibits the sensitivity of lung cancer cells to cisplatin via negative regulation of Apaf-1 expression. Cancer Gene Ther. 2012, 19, 773-778. [CrossRef] [PubMed]

367. Ling, N.; Gu, J.; Lei, Z.; Li, M.; Zhao, J.; Zhang, H.T.; Li, X. MicroRNA-155 regulates cell proliferation and invasion by targeting FOXO3a in glioma. Oncol. Rep. 2013, 30, 2111-2118. [PubMed]

368. Azimzadeh, M.; Rahaie, M.; Nasirizadeh, N.; Ashtari, K.; Naderi-Manesh, H. An electrochemical nanobiosensor for plasma miRNA-155, based on graphene oxide and gold nanorod, for early detection of breast cancer. Biosens. Bioelectron. 2016, 77, 99-106. [CrossRef] [PubMed]

369. Paik, W.H.; Song, B.J.; Kim, H.W.; Kim, H.R.; Hwang, J.H. MicroRNA-200c as a Prognostic Biomarker for Pancreatic Cancer. Korean J. Gastroenterol. 2015, 66, 215-220. [CrossRef] [PubMed]

370. Zaravinos, A. The Regulatory Role of MicroRNAs in EMT and Cancer. J. Oncol. 2015, 2015, 865816. [CrossRef] [PubMed]

371. Choi, Y.C.; Yoon, S.; Jeong, Y.; Yoon, J.; Baek, K. Regulation of vascular endothelial growth factor signaling by miR-200b. Mol. Cells 2011, 32, 77-82. [CrossRef] [PubMed]

372. McArthur, K.; Feng, B.; Wu, Y.; Chen, S.; Chakrabarti, S. MicroRNA-200b regulates vascular endothelial growth factor-mediated alterations in diabetic retinopathy. Diabetes 2011, 60, 1314-1323. [CrossRef] [PubMed]

373. Pecot, C.V.; Rupaimoole, R.; Yang, D.; Akbani, R.; Ivan, C.; Lu, C.; Wu, S.; Han, H.D.; Shah, M.Y.; Rodriguez-Aguayo, C.; et al. Tumour angiogenesis regulation by the miR-200 family. Nat. Commun. 2013, 4, 2427. [CrossRef] [PubMed]

374. Wang, X.L.; Xie, H.Y.; Zhu, C.D.; Zhu, X.F.; Cao, G.X.; Chen, X.H.; Xu, H.F. Increased miR-141 expression is associated with diagnosis and favorable prognosis of patients with bladder cancer. Tumour Biol. 2015, 36, 877-883. [CrossRef] [PubMed]

375. Fasanaro, P.; D’Alessandra, Y.; di Stefano, V.; Melchionna, R.; Romani, S.; Pompilio, G.; Capogrossi, M.C.; Martelli, F. MicroRNA-210 modulates endothelial cell response to hypoxia and inhibits the receptor tyrosine kinase ligand Ephrin-A3. J. Biol. Chem. 2008, 283, 15878-15883. [CrossRef] [PubMed]

376. Pulkkinen, K.; Malm, T.; Turunen, M.; Koistinaho, J.; Yla-Herttuala, S. Hypoxia induces microRNA miR-210 in vitro and in vivo ephrin-A3 and neuronal pentraxin 1 are potentially regulated by miR-210. FEBS Lett. 2008, 582, 2397-2401. [CrossRef] [PubMed]

377. Foekens, J.A.; Sieuwerts, A.M.; Smid, M.; Look, M.P.; de Weerd, V.; Boersma, A.W.; Klijn, J.G.; Wiemer, E.A.; Martens, J.W. Four miRNAs associated with aggressiveness of lymph node-negative, estrogen receptor-positive human breast cancer. Proc. Natl. Acad. Sci. USA 2008, 105, 13021-13026. [CrossRef] [PubMed]

378. Okamoto, M.; Nasu, K.; Abe, W.; Aoyagi, Y.; Kawano, Y.; Kai, K.; Moriyama, M.; Narahara, H. Enhanced miR-210 expression promotes the pathogenesis of endometriosis through activation of signal transducer and activator of transcription 3. Hum. Reprod. 2015, 30, 632-641. [CrossRef] [PubMed]

379. Zhang, Z.; Sun, H.; Dai, H.; Walsh, R.M.; Imakura, M.; Schelter, J.; Burchard, J.; Dai, X.; Chang, A.N.; Diaz, R.L.; et al. MicroRNA miR-210 modulates cellular response to hypoxia through the MYC antagonist MNT. Cell Cycle 2009, 8, 2756-2768. [CrossRef] [PubMed]

380. Giannakakis, A.; Sandaltzopoulos, R.; Greshock, J.; Liang, S.; Huang, J.; Hasegawa, K.; Li, C.; O'Brien-Jenkins, A.; Katsaros, D.; Weber, B.L.; et al. miR-210 links hypoxia with cell cycle regulation and is deleted in human epithelial ovarian cancer. Cancer Biol. Ther. 2008, 7, 255-264. [CrossRef] [PubMed]

381. Nakada, C.; Tsukamoto, Y.; Matsuura, K.; Nguyen, T.L.; Hijiya, N.; Uchida, T.; Sato, F.; Mimata, H.; Seto, M.; Moriyama, M. Overexpression of miR-210, a downstream target of $\mathrm{HIF} 1 \alpha$, causes centrosome amplification in renal carcinoma cells. J. Pathol. 2011, 224, 280-288. [CrossRef] [PubMed] 
382. Tsuchiya, S.; Fujiwara, T.; Sato, F.; Shimada, Y.; Tanaka, E.; Sakai, Y.; Shimizu, K.; Tsujimoto, G. MicroRNA-210 regulates cancer cell proliferation through targeting fibroblast growth factor receptor-like 1 (FGFRL1). J. Biol. Chem. 2011, 286, 420-428. [CrossRef] [PubMed]

383. Qiu, J.; Zhou, X.Y.; Zhou, X.G.; Cheng, R.; Liu, H.Y.; Li, Y. Neuroprotective effects of microRNA-210 against oxygen-glucose deprivation through inhibition of apoptosis in PC12 cells. Mol. Med. Rep. 2013, 7, 1955-1959. [CrossRef] [PubMed]

384. Chio, C.C.; Lin, J.W.; Cheng, H.A.; Chiu, W.T.; Wang, Y.H.; Wang, J.J.; Hsing, C.H.; Chen, R.M. MicroRNA-210 targets antiapoptotic Bcl-2 expression and mediates hypoxia-induced apoptosis of neuroblastoma cells. Arch. Toxicol. 2013, 87, 459-468. [CrossRef] [PubMed]

385. Crosby, M.E.; Kulshreshtha, R.; Ivan, M.; Glazer, P.M. MicroRNA regulation of DNA repair gene expression in hypoxic stress. Cancer Res. 2009, 69, 1221-1229. [CrossRef] [PubMed]

386. Huang, X.; Ding, L.; Bennewith, K.L.; Tong, R.T.; Welford, S.M.; Ang, K.K.; Story, M.; Le, Q.T.; Giaccia, A.J. Hypoxia-inducible miR-210 regulates normoxic gene expression involved in tumor initiation. Mol. Cell 2009, 35, 856-867. [CrossRef] [PubMed]

387. Urbich, C.; Kuehbacher, A.; Dimmeler, S. Role of microRNAs in vascular diseases, inflammation, and angiogenesis. Cardiovasc. Res. 2008, 79, 581-588. [CrossRef] [PubMed]

388. Poliseno, L.; Tuccoli, A.; Mariani, L.; Evangelista, M.; Citti, L.; Woods, K.; Mercatanti, A.; Hammond, S.; Rainaldi, G. MicroRNAs modulate the angiogenic properties of HUVECs. Blood 2006, 108, 3068-3071. [CrossRef] [PubMed]

389. Ye, X.; Bai, W.; Zhu, H.; Zhang, X.; Chen, Y.; Wang, L.; Yang, A.; Zhao, J.; Jia, L. miR-221 promotes trastuzumab-resistance and metastasis in HER2-positive breast cancers by targeting PTEN. BMB Rep. 2014, 47, 268-273. [CrossRef] [PubMed]

390. Garofalo, M.; Di Leva, G.; Romano, G.; Nuovo, G.; Suh, S.S.; Ngankeu, A.; Taccioli, C.; Pichiorri, F.; Alder, H.; Secchiero, P.; et al. miR-221\&222 regulate TRAIL resistance and enhance tumorigenicity through PTEN and TIMP3 downregulation. Cancer Cell 2009, 16, 498-509. [PubMed]

391. Suarez, Y.; Fernandez-Hernando, C.; Pober, J.S.; Sessa, W.C. Dicer dependent microRNAs regulate gene expression and functions in human endothelial cells. Circ. Res. 2007, 100, 1164-1173. [CrossRef] [PubMed]

392. Cai, G.; Qiao, S.; Chen, K. Suppression of miR-221 inhibits glioma cells proliferation and invasion via targeting SEMA3B. Biol. Res. 2015, 48, 37. [CrossRef] [PubMed]

393. Kneitz, B.; Krebs, M.; Kalogirou, C.; Schubert, M.; Joniau, S.; van Poppel, H.; Lerut, E.; Kneitz, S.; Scholz, C.J.; Strobel, P.; et al. Survival in patients with high-risk prostate cancer is predicted by miR-221, which regulates proliferation, apoptosis, and invasion of prostate cancer cells by inhibiting IRF2 and SOCS3. Cancer Res. 2014, 74, 2591-2603. [CrossRef] [PubMed]

394. Zhong, C.; Ding, S.; Xu, Y.; Huang, H. MicroRNA-222 promotes human non-small cell lung cancer H460 growth by targeting p27. Int. J. Clin. Exp. Med. 2015, 8, 5534-5540. [PubMed]

395. Yang, C.J.; Shen, W.G.; Liu, C.J.; Chen, Y.W.; Lu, H.H.; Tsai, M.M.; Lin, S.C. MiR-221 and miR-222 expression increased the growth and tumorigenesis of oral carcinoma cells. J. Oral Pathol. Med. 2011, 40, 560-566. [CrossRef] [PubMed]

396. Sun, T.; Wang, X.; He, H.H.; Sweeney, C.J.; Liu, S.X.; Brown, M.; Balk, S.; Lee, G.S.; Kantoff, P.W. miR-221 promotes the development of androgen independence in prostate cancer cells via downregulation of HECTD2 and RAB1A. Oncogene 2014, 33, 2790-2800. [CrossRef] [PubMed]

397. Rao, X.; Di Leva, G.; Li, M.; Fang, F.; Devlin, C.; Hartman-Frey, C.; Burow, M.E.; Ivan, M.; Croce, C.M.; Nephew, K.P. MicroRNA-221/222 confers breast cancer fulvestrant resistance by regulating multiple signaling pathways. Oncogene 2011, 30, 1082-1097. [CrossRef] [PubMed]

398. Dentelli, P.; Traversa, M.; Rosso, A.; Togliatto, G.; Olgasi, C.; Marchio, C.; Provero, P.; Lembo, A.; Bon, G.; Annaratone, L.; et al. miR-221/222 control luminal breast cancer tumor progression by regulating different targets. Cell Cycle 2014, 13, 1811-1826. [CrossRef] [PubMed]

399. Zhang, C.Z.; Zhang, J.X.; Zhang, A.L.; Shi, Z.D.; Han, L.; Jia, Z.F.; Yang, W.D.; Wang, G.X.; Jiang, T.; You, Y.P.; et al. miR-221 and miR-222 target PUMA to induce cell survival in glioblastoma. Mol. Cancer 2010, 9, 229. [CrossRef] [PubMed] 
400. Goto, Y.; Kojima, S.; Nishikawa, R.; Kurozumi, A.; Kato, M.; Enokida, H.; Matsushita, R.; Yamazaki, K.; Ishida, Y.; Nakagawa, M.; et al. MicroRNA expression signature of castration-resistant prostate cancer: The microRNA-221/222 cluster functions as a tumour suppressor and disease progression marker. Br. J. Cancer 2015, 113, 1055-1065. [CrossRef] [PubMed]

401. Ding, L.; Xu, Y.; Zhang, W.; Deng, Y.; Si, M.; Du, Y.; Yao, H.; Liu, X.; Ke, Y.; Si, J.; et al. miR-375 frequently downregulated in gastric cancer inhibits cell proliferation by targeting JAK2. Cell Res. 2010, 20, 784-793. [CrossRef] [PubMed]

402. Tsukamoto, Y.; Nakada, C.; Noguchi, T.; Tanigawa, M.; Nguyen, L.T.; Uchida, T.; Hijiya, N.; Matsuura, K.; Fujioka, T.; Seto, M.; et al. MicroRNA-375 is downregulated in gastric carcinomas and regulates cell survival by targeting PDK1 and 14-3-3zeta. Cancer Res. 2010, 70, 2339-2349. [CrossRef] [PubMed]

403. Song, S.D.; Zhou, J.; Zhou, J.; Zhao, H.; Cen, J.N.; Li, D.C. MicroRNA-375 targets the 3-phosphoinositide-dependent protein kinase-1 gene in pancreatic carcinoma. Oncol. Lett. 2013, 6, 953-959. [PubMed]

404. Luo, J.; Wu, J.; Li, Z.; Qin, H.; Wang, B.; Wong, T.S.; Yang, W.; Fu, Q.L.; Lei, W. miR-375 suppresses IGF1R expression and contributes to inhibition of cell progression in laryngeal squamous cell carcinoma. BioMed Res. Int. 2014, 2014, 374598. [CrossRef] [PubMed]

405. Mao, Q.; Quan, T.; Luo, B.; Guo, X.; Liu, L.; Zheng, Q. MiR-375 targets KLF4 and impacts the proliferation of colorectal carcinoma. Tumour Biol. 2015. [CrossRef] [PubMed]

406. Shi, W.; Yang, J.; Li, S.; Shan, X.; Liu, X.; Hua, H.; Zhao, C.; Feng, Z.; Cai, Z.; Zhang, L.; et al. Potential involvement of miR-375 in the premalignant progression of oral squamous cell carcinoma mediated via transcription factor KLF5. Oncotarget 2015, 6, 40172-40185. [PubMed]

407. Wang, X.Z.; Hang, Y.K.; Liu, J.B.; Hou, Y.Q.; Wang, N.; Wang, M.J. Over-expression of microRNA-375 inhibits papillary thyroid carcinoma cell proliferation and induces cell apoptosis by targeting ERBB2. J. Pharmacol. Sci. 2016, 130, 78-84. [CrossRef] [PubMed]

408. Shen, Z.Y.; Zhang, Z.Z.; Liu, H.; Zhao, E.H.; Cao, H. miR-375 inhibits the proliferation of gastric cancer cells by repressing ERBB2 expression. Exp. Ther. Med. 2014, 7, 1757-1761. [CrossRef] [PubMed]

409. Wang, Y.; Tang, Q.; Li, M.; Jiang, S.; Wang, X. MicroRNA-375 inhibits colorectal cancer growth by targeting PIK3CA. Biochem. Biophys. Res. Commun. 2014, 444, 199-204. [CrossRef] [PubMed]

410. He, J.; Cao, Y.; Su, T.; Jiang, Y.; Jiang, L.; Zhou, W.; Zhang, C.; Wang, W.; Ning, G. Downregulation of miR-375 in aldosterone-producing adenomas promotes tumour cell growth via MTDH. Clin. Endocrinol. (Oxf.) 2015, 83, 581-589. [CrossRef] [PubMed]

411. Hudson, J.; Duncavage, E.; Tamburrino, A.; Salerno, P.; Xi, L.; Raffeld, M.; Moley, J.; Chernock, R.D. Overexpression of miR-10a and miR-375 and downregulation of YAP1 in medullary thyroid carcinoma. Exp. Mol. Pathol. 2013, 95, 62-67. [CrossRef] [PubMed]

412. Jung, H.M.; Patel, R.S.; Phillips, B.L.; Wang, H.; Cohen, D.M.; Reinhold, W.C.; Chang, L.J.; Yang, L.J.; Chan, E.K. Tumor suppressor miR-375 regulates MYC expression via repression of CIP2A coding sequence through multiple miRNA-mRNA interactions. Mol. Biol. Cell 2013, 24, 1638-1648. [CrossRef] [PubMed]

413. He, X.X.; Chang, Y.; Meng, F.Y.; Wang, M.Y.; Xie, Q.H.; Tang, F.; Li, P.Y.; Song, Y.H.; Lin, J.S. MicroRNA-375 targets AEG-1 in hepatocellular carcinoma and suppresses liver cancer cell growth in vitro and in vivo. Oncogene 2012, 31, 3357-3369. [CrossRef] [PubMed]

414. Zaharie, F.; Muresan, M.S.; Petrushev, B.; Berce, C.; Gafencu, G.A.; Selicean, S.; Jurj, A.; Cojocneanu-Petric, R.; Lisencu, C.I.; Pop, L.A.; et al. Exosome-Carried microRNA-375 Inhibits Cell Progression and Dissemination via Bcl-2 Blocking in Colon Cancer. J. Gastroint. Liver Dis. 2015, 24, 435-443.

415. Yoda, S.; Soejima, K.; Hamamoto, J.; Yasuda, H.; Nakayama, S.; Satomi, R.; Terai, H.; Ikemura, S.; Sato, T.; Naoki, K.; et al. Claudin-1 is a novel target of miR-375 in non-small-cell lung cancer. Lung Cancer 2014, 85, 366-372. [CrossRef] [PubMed]

416. Ye, X.M.; Zhu, H.Y.; Bai, W.D.; Wang, T.; Wang, L.; Chen, Y.; Yang, A.G.; Jia, L.T. Epigenetic silencing of miR-375 induces trastuzumab resistance in HER2-positive breast cancer by targeting IGF1R. BMC Cancer 2014, 14, 134. [CrossRef] [PubMed]

417. Liu, Y.; Xing, R.; Zhang, X.; Dong, W.; Zhang, J.; Yan, Z.; Li, W.; Cui, J.; Lu, Y. miR-375 targets the p53 gene to regulate cellular response to ionizing radiation and etoposide in gastric cancer cells. DNA Repair. (Amst.) 2013, 12, 741-750. [CrossRef] [PubMed] 
418. Mussnich, P.; Rosa, R.; Bianco, R.; Fusco, A.; D'Angelo, D. miR-199a-5p and miR-375 affect colon cancer cell sensitivity to cetuximab by targeting PHLPP1. Expert Opin. Ther. Targets 2015, 19, 1017-1026. [CrossRef] [PubMed]

419. Hong, S.; Noh, H.; Teng, Y.; Shao, J.; Rehmani, H.; Ding, H.F.; Dong, Z.; Su, S.B.; Shi, H.; Kim, J.; et al. SHOX2 is a direct miR-375 target and a novel epithelial-to-mesenchymal transition inducer in breast cancer cells. Neoplasia 2014, 16, 279-290. [CrossRef] [PubMed]

420. Chang, Y.; Yan, W.; He, X.; Zhang, L.; Li, C.; Huang, H.; Nace, G.; Geller, D.A.; Lin, J.; Tsung, A. miR-375 inhibits autophagy and reduces viability of hepatocellular carcinoma cells under hypoxic conditions. Gastroenterology 2012, 143, 177-187. [CrossRef] [PubMed]

421. Szigeti, A.; Tatrai, E.; Szamosi, A.; Vargha, P.; Nagy, Z.Z.; Nemeth, J.; DeBuc, D.C.; Somfai, G.M. A morphological study of retinal changes in unilateral amblyopia using optical coherence tomography image segmentation. PLoS ONE 2014, 9, e88363. [CrossRef] [PubMed]

422. Park, N.J.; Zhou, X.; Yu, T.; Brinkman, B.M.; Zimmermann, B.G.; Palanisamy, V.; Wong, D.T. Characterization of salivary RNA by cDNA library analysis. Arch. Oral Biol. 2007, 52, 30-35. [CrossRef] [PubMed]

423. Weber, J.A.; Baxter, D.H.; Zhang, S.; Huang, D.Y.; Huang, K.H.; Lee, M.J.; Galas, D.J.; Wang, K. The microRNA spectrum in 12 body fluids. Clin. Chem. 2010, 56, 1733-1741. [CrossRef] [PubMed]

424. Liu, C.J.; Lin, S.C.; Yang, C.C.; Cheng, H.W.; Chang, K.W. Exploiting salivary miR-31 as a clinical biomarker of oral squamous cell carcinoma. Head Neck 2012, 34, 219-224. [CrossRef] [PubMed]

425. Momen-Heravi, F.; Trachtenberg, A.J.; Kuo, W.P.; Cheng, Y.S. Genomewide Study of Salivary MicroRNAs for Detection of Oral Cancer. J. Dent. Res. 2014, 93, 86S-93S. [CrossRef] [PubMed]

426. Zahran, F.; Ghalwash, D.; Shaker, O.; Al-Johani, K.; Scully, C. Salivary microRNAs in oral cancer. Oral Dis. 2015, 21, 739-747. [CrossRef] [PubMed]

427. Duz, M.B.; Karatas, O.F.; Guzel, E.; Turgut, N.F.; Yilmaz, M.; Creighton, C.J.; Ozen, M. Identification of miR-139-5p as a saliva biomarker for tongue squamous cell carcinoma: A pilot study. Cell. Oncol. (Dordr.) 2015. [CrossRef] [PubMed]

428. Matse, J.H.; Yoshizawa, J.; Wang, X.; Elashoff, D.; Bolscher, J.G.; Veerman, E.C.; Bloemena, E.; Wong, D.T. Discovery and prevalidation of salivary extracellular microRNA biomarkers panel for the noninvasive detection of benign and malignant parotid gland tumors. Clin. Cancer Res. 2013, 19, 3032-3038. [CrossRef] [PubMed]

429. Xie, Z.; Yin, X.; Gong, B.; Nie, W.; Wu, B.; Zhang, X.; Huang, J.; Zhang, P.; Zhou, Z.; Li, Z. Salivary microRNAs show potential as a noninvasive biomarker for detecting resectable pancreatic cancer. Cancer Prev. Res. (Phila) 2015, 8, 165-173. [CrossRef] [PubMed]

430. Huang, X.; Liang, M.; Dittmar, R.; Wang, L. Extracellular microRNAs in urologic malignancies: Chances and challenges. Int. J. Mol. Sci. 2013, 14, 14785-14799. [CrossRef] [PubMed]

431. Zhou, J.; Gong, G.; Tan, H.; Dai, F.; Zhu, X.; Chen, Y.; Wang, J.; Liu, Y.; Chen, P.; Wu, X.; et al. Urinary microRNA-30a-5p is a potential biomarker for ovarian serous adenocarcinoma. Oncol. Rep. 2015, 33, 2915-2923. [CrossRef] [PubMed]

432. Abdalla, M.A.; Haj-Ahmad, Y. Promising Candidate Urinary MicroRNA Biomarkers for the Early Detection of Hepatocellular Carcinoma among High-Risk Hepatitis C Virus Egyptian Patients. J. Cancer 2012, 3, $19-31$. [CrossRef] [PubMed]

433. Machida, A.; Ohkubo, T.; Yokota, T. Circulating microRNAs in the cerebrospinal fluid of patients with brain diseases. Methods Mol. Biol. 2013, 1024, 203-209. [PubMed]

434. Baraniskin, A.; Kuhnhenn, J.; Schlegel, U.; Chan, A.; Deckert, M.; Gold, R.; Maghnouj, A.; Zollner, H.; Reinacher-Schick, A.; Schmiegel, W.; et al. Identification of microRNAs in the cerebrospinal fluid as marker for primary diffuse large B-cell lymphoma of the central nervous system. Blood 2011, 117, 3140-3146. [CrossRef] [PubMed]

435. Baraniskin, A.; Kuhnhenn, J.; Schlegel, U.; Maghnouj, A.; Zollner, H.; Schmiegel, W.; Hahn, S.; Schroers, R. Identification of microRNAs in the cerebrospinal fluid as biomarker for the diagnosis of glioma. Neuro Oncol. 2012, 14, 29-33. [CrossRef] [PubMed]

436. Baraniskin, A.; Kuhnhenn, J.; Schlegel, U.; Schmiegel, W.; Hahn, S.; Schroers, R. MicroRNAs in cerebrospinal fluid as biomarker for disease course monitoring in primary central nervous system lymphoma. J. Neurooncol. 2012, 109, 239-244. [CrossRef] [PubMed] 
437. Tuo, J.; Shen, D.; Yang, H.H.; Chan, C.C. Distinct microRNA-155 expression in the vitreous of patients with primary vitreoretinal lymphoma and uveitis. Am. J. Ophthalmol. 2014, 157, 728-734. [CrossRef] [PubMed]

438. Ragusa, M.; Caltabiano, R.; Russo, A.; Puzzo, L.; Avitabile, T.; Longo, A.; Toro, M.D.; di Pietro, C.; Purrello, M.; Reibaldi, M. MicroRNAs in vitreus humor from patients with ocular diseases. Mol. Vis. 2013, 19, 430-440. [PubMed]

439. Gu, Y.Q.; Gong, G.; Xu, Z.L.; Wang, L.Y.; Fang, M.L.; Zhou, H.; Xing, H.; Wang, K.R.; Sun, L. miRNA profiling reveals a potential role of milk stasis in breast carcinogenesis. Int. J. Mol. Med. 2014, 33, 1243-1249. [CrossRef] [PubMed]

440. Selth, L.A.; Roberts, M.J.; Chow, C.W.; Marshall, V.R.; Doi, S.A.; Vincent, A.D.; Butler, L.M.; Lavin, M.F.; Tilley, W.D.; Gardiner, R.A. Human seminal fluid as a source of prostate cancer-specific microRNA biomarkers. Endocr. Relat. Cancer 2014, 21, L17-L21. [CrossRef] [PubMed]

441. Margue, C.; Reinsbach, S.; Philippidou, D.; Beaume, N.; Walters, C.; Schneider, J.G.; Nashan, D.; Behrmann, I.; Kreis, S. Comparison of a healthy miRNome with melanoma patient miRNomes: Are microRNAs suitable serum biomarkers for cancer? Oncotarget 2015, 6, 12110-12127. [CrossRef] [PubMed]

442. Witwer, K.W.; Buzas, E.I.; Bemis, L.T.; Bora, A.; Lasser, C.; Lotvall, J.; Nolte-'t Hoen, E.N.; Piper, M.G.; Sivaraman, S.; Skog, J.; et al. Standardization of sample collection, isolation and analysis methods in extracellular vesicle research. J. Extracell. Vesicles 2013, 2, 20360. [CrossRef] [PubMed]

443. McDonald, J.S.; Milosevic, D.; Reddi, H.V.; Grebe, S.K.; Algeciras-Schimnich, A. Analysis of circulating microRNA: Preanalytical and analytical challenges. Clin. Chem. 2011, 57, 833-840. [CrossRef] [PubMed]

444. Kirschner, M.B.; Kao, S.C.; Edelman, J.J.; Armstrong, N.J.; Vallely, M.P.; van Zandwijk, N.; Reid, G. Haemolysis during sample preparation alters microRNA content of plasma. PLoS ONE 2011, 6, e24145. [CrossRef] [PubMed]

445. Pritchard, C.C.; Kroh, E.; Wood, B.; Arroyo, J.D.; Dougherty, K.J.; Miyaji, M.M.; Tait, J.F.; Tewari, M. Blood cell origin of circulating microRNAs: A cautionary note for cancer biomarker studies. Cancer Prev. Res. (Phila) 2012, 5, 492-497. [CrossRef] [PubMed]

446. Kannan, M.; Atreya, C. Differential profiling of human red blood cells during storage for 52 selected microRNAs. Transfusion 2010, 50, 1581-1588. [CrossRef] [PubMed]

447. Al-Soud, W.A.; Radstrom, P. Purification and characterization of PCR-inhibitory components in blood cells. J. Clin. Microbiol. 2001, 39, 485-493. [CrossRef] [PubMed]

448. Heneghan, H.M.; Miller, N.; Kerin, M.J. Circulating miRNA signatures: Promising prognostic tools for cancer. J. Clin. Oncol. 2010, 28, e573-e574. [CrossRef] [PubMed]

449. Gourzones, C.; Ferrand, F.R.; Amiel, C.; Verillaud, B.; Barat, A.; Guerin, M.; Gattolliat, C.H.; Gelin, A.; Klibi, J.; Chaaben, A.B.; et al. Consistent high concentration of the viral microRNA BART17 in plasma samples from nasopharyngeal carcinoma patients-Evidence of non-exosomal transport. Virol. J. 2013, 10, 119. [CrossRef] [PubMed]

450. Hu, J.; Wang, Z.; Tan, C.J.; Liao, B.Y.; Zhang, X.; Xu, M.; Dai, Z.; Qiu, S.J.; Huang, X.W.; Sun, J.; et al. Plasma microRNA, a potential biomarker for acute rejection after liver transplantation. Transplantation 2013, 95, 991-999. [CrossRef] [PubMed]

451. Cheng, H.H.; Yi, H.S.; Kim, Y.; Kroh, E.M.; Chien, J.W.; Eaton, K.D.; Goodman, M.T.; Tait, J.F.; Tewari, M.; Pritchard, C.C. Plasma processing conditions substantially influence circulating microRNA biomarker levels. PLoS ONE 2013, 8, e64795. [CrossRef] [PubMed]

452. Kim, Y.K.; Yeo, J.; Kim, B.; Ha, M.; Kim, V.N. Short structured RNAs with low GC content are selectively lost during extraction from a small number of cells. Mol. Cell 2012, 46, 893-895. [CrossRef] [PubMed]

453. Whitney, A.R.; Diehn, M.; Popper, S.J.; Alizadeh, A.A.; Boldrick, J.C.; Relman, D.A.; Brown, P.O. Individuality and variation in gene expression patterns in human blood. Proc. Natl. Acad. Sci. USA 2003, 100, 1896-1901. [CrossRef] [PubMed]

454. Watson, A.K.; Witwer, K.W. Do platform-specific factors explain microRNA profiling disparities? Clin. Chem. 2012, 58, 472-474. [CrossRef] [PubMed]

455. Dickinson, B.; Zhang, Y.; Petrick, J.S.; Heck, G.; Ivashuta, S.; Marshall, W.S. Lack of detectable oral bioavailability of plant microRNAs after feeding in mice. Nat. Biotechnol. 2013, 31, 965-967. [CrossRef] [PubMed]

456. Haider, B.A.; Baras, A.S.; McCall, M.N.; Hertel, J.A.; Cornish, T.C.; Halushka, M.K. A critical evaluation of microRNA biomarkers in non-neoplastic disease. PLoS ONE 2014, 9, e89565. [CrossRef] [PubMed] 
457. Xiang, M.; Zeng, Y.; Yang, R.; Xu, H.; Chen, Z.; Zhong, J.; Xie, H.; Xu, Y.; Zeng, X. U6 is not a suitable endogenous control for the quantification of circulating microRNAs. Biochem. Biophys. Res. Commun. 2014, 454, 210-214. [CrossRef] [PubMed]

458. McDermott, A.M.; Kerin, M.J.; Miller, N. Identification and validation of miRNAs as endogenous controls for RQ-PCR in blood specimens for breast cancer studies. PLoS ONE 2013, 8, e83718. [CrossRef] [PubMed]

459. Murata, K.; Furu, M.; Yoshitomi, H.; Ishikawa, M.; Shibuya, H.; Hashimoto, M.; Imura, Y.; Fujii, T.; Ito, H.; Mimori, T.; et al. Comprehensive microRNA analysis identifies miR-24 and miR-125a-5p as plasma biomarkers for rheumatoid arthritis. PLOS ONE 2013, 8, e69118. [CrossRef] [PubMed] article distributed under the terms and conditions of the Creative Commons Attribution (CC-BY) license (http://creativecommons.org/licenses/by/4.0/). 